\title{
P(EMA-co-HEA)/SiO HYBRID NANOCOMPOSITES FOR GUIDED DENTIN TISSUE REGENERATION: STRUCTURE, CHARACTERIZATION AND BIOACTIVITY
}

\author{
Ana Vallés Lluch \\ Dr. Eng. Sci. Thesis
}

Valencia (Spain), 2008 



\title{
P(EMA-co-HEA $) / \mathrm{SiO}_{2}$ HYBRID NANOCOMPOSITES FOR GUIDED DENTIN TISSUE REGENERATION: STRUCTURE, CHARACTERIZATION AND BIOACTIVITY
}

\author{
Thesis submitted by \\ Ana Vallés Lluch \\ to obtain the degree of Dr. Eng. Sci. \\ at the Polytechnic University of Valencia \\ Valencia (Spain), 2008
}

Thesis supervisors: Prof. Dr. Manuel Monleón Pradas

Dr. Gloria Gallego Ferrer 
Members of the Jury:

Prof. Dr. José Luis Gómez Ribelles

Dpt. of Applied Thermodynamics and Center for Biomaterials and Tissue Engineering,

Polytechnic University of Valencia, Spain

Dr. Manuel Salmerón Sánchez

Dpt. of Applied Physics and Center for Biomaterials and Tissue Engineering,

Polytechnic University of Valencia, Spain

Prof. Dr. Polykarpos Pissis

Dpt. of Physics,

National Technical University of Athens, Greece

Prof. Dr. Daniel Beltrán Porter

Dpt. of Inorganic Chemistry and Institute for Materials Science,

University of Valencia, Spain

Prof. Dr. Jean Marc Saiter

Dpt. of Physics,

University of Rouen, France

The research described in this thesis was carried out at the Center for Biomaterials and Tissue Engineering of the Polytechnic University of Valencia, Spain. The work was partially funded by the Generalitat Valenciana under the projects CV04A/494 "Materiales sintéticos para regeneración dentinaria guiada" and $\mathrm{AE} / 07 / 050$ "Nuevos biomateriales para la regeneración de tejidos dentales". 
Per a David, Carles i Marc, amb molta estima 



\section{Acknowledgements}

I would like to express my gratitude to all of you with whom I have shared these last years. All of you have contributed to make this work possible, in one way or another.

I would like to say a big thanks to all the people of the Centre for Biomaterials and Tissue Engineering: professors, doctoral students and technicians, for creating a scientifically stimulating and most importantly such a friendly (coffee smelling) atmosphere. Thanks especially to Gloria, Manuel Monleón, Joseka, Alberto, Elisa and Manuel Salmerón. It is a pleasure to work with all of you!

I am also grateful to the staff of the Microscopy Service of the Polytechnic University of Valencia for their valuable help during the not few SEM-EDS sessions, to Dr. $\mathrm{M}^{\mathrm{a}}$ Carmen Millán (Department of Applied Physics, Polytechnic University of Valencia) for her help with the XRD measurements, to Mario Soriano Navarro and Dr. José Manuel García Verdugo from the Centro de Investigación Príncipe Felipe, Valencia, where the TEM images were obtained, to Dr. Carmen Carda Batalla (Pathology Department, Faculty of Medicine and Odontology, University of Valencia) for fruitful discussions and performing the in vivo experiments and histological analyses and to Dr. Leopoldo Forner Navarro (Stomatology Department, Faculty of Medicine and Odontology, University of Valencia), Drs. Marica and Hrvoje Ivanković (Department of Physical Chemistry, Faculty of Chemical Engineering and Technology, University of Zagreb) for their valuable advises.

I would like to thank my parents, brother and sister for their endless support and patience, and finally my most special thanks to David for his love and constant encouragement and to Carles and Marc for continuously reminding me the essential things in life. I love you! 



\section{Contents}

Abstract $\quad$ XI

Resumen $\quad$ XV

Resum

1. Introduction 1

1.1 Dentin 1

1.1.1 Structure and composition $\quad 1$

1.1.2 Dentinogenesis and dentinogenic responses to injury 4

1.1.3 Dentin/pulp therapies $\quad 6$

1.1.4. Tissue engineering applied to the regeneration of pulp and dentin in $\begin{array}{ll}\text { endodontics } & 7\end{array}$

1.2 Bioactivity 11

1.2.1 Requirement for bone bonding: in vivo bioactivity 11

1.2.2 Biomimetic in vitro test for predicting the in vivo bioactivity 12

1.2.3 Mechanism of apatite formation on bioactive glasses 16

1.2.4 Biomimetic approaches to bioactive materials for hard tissue

engineering: bioactive hybrids and bioactive surface functionalization 20

1.3 Polymer/silica nanohybrids obtained by sol-gel process 24

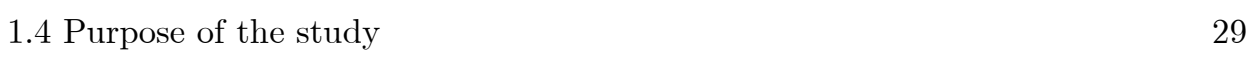

2. Materials and methods $\quad 31$

2.1 Materials 31

2.1.1 Bulk samples $\quad 31$

2.1.2 Scaffolds of tubular parallel channels 34

2.2 In vitro test of bone bonding ability in SBF 35

2.3 Surface treatments prior to the immersion in SBF 37

2.4 Experimental techniques 38

2.4.1 Fourier-Transform Infrared Spectrometry (FTIR) 38

2.4.2 Scanning Electron Microscopy (SEM) 38

2.4.3 Energy Dispersive X-ray Spectroscopy (EDS) 38 
Contents

2.4.4 Thermogravimetric Analysis (TGA) 39

2.4.5 Pyrolysis 39

2.4.6 Specific volume $\quad 39$

2.4.7 Porosity 40

2.4.8 Transmission Electron Microscopy (TEM) 41

2.4.9 Solvent uptake $\quad 41$

2.4.10 Contact angle measurements $\quad 42$

2.4.11 Differential Scanning Calorimetry (DSC) 43

2.4.12 Dynamic-Mechanical Spectroscopy (DMS) 44

2.4.13 Compression tests 44

2.4.14 X-Ray Diffraction (XRD) 44

3. Results $\quad 45$

3.1 Structure of $\mathrm{SiO}_{2}$ in the $\mathrm{P}(\mathrm{EMA}-$ co-HEA) matrix

3.1.1 Fourier-Transformed Infrared Analysis $\quad 45$

3.1.2 Energy Dispersive X-ray Spectroscopy 48

3.1.3 Thermogravimetric Analysis $\quad 49$

3.1.4 Pyrolysis 51

3.1.5 Transmission Electron Microscopy $\quad 52$

3.1.6 Solvent uptake $\quad 54$

3.2 Characterization of $\mathrm{P}(\mathrm{EMA}-\mathrm{co}-\mathrm{HEA}) / \mathrm{SiO}_{2}$ nanocomposites 56

3.2.1 Dynamic-Mechanical Spectroscopy 56

$\begin{array}{ll}3.2 .2 \text { Specific volume } & 59\end{array}$

3.2.3 Surface tension $\quad 60$

3.2.4 Differential Scanning Calorimetry $\quad 61$

3.2.5 Compression tests 63

3.3 Bioactivity of $\mathrm{P}(\mathrm{EMA}-\mathrm{co}-\mathrm{HEA}) / \mathrm{SiO}_{2}$ nanocomposites $\quad 65$

3.3.1 Characterization of the apatite formed on the substrates in SBF 65

3.3.2 Structural changes of the nanocomposites in the SBF 76

3.4 Surface treatments as a means of reducing the apatite nucleation induction times $\quad 81$

3.4.1 Surface structural changes of the substrates due to the $\mathrm{NaOH}$ treatment $\quad 81$

3.4.2 Characterization of the apatite formed on the $\mathrm{NaOH}$-treated substrates $\quad 84$

3.4.3 Surface structural changes of the substrates due to the CaP treatment 86

3.4.4 Characterization of the apatite formed on the CaP-treated substrates $\quad 89$

3.5 Bioactive $\mathrm{P}(\mathrm{EMA}-\mathrm{co}-\mathrm{HEA}) / \mathrm{SiO}_{2}$ scaffolds mimicking natural dentin structure 
3.5.1 Structure of the $\mathrm{P}$ (EMA-co-HEA)/ $\mathrm{SiO}$ nanohybrid scaffolds

\section{Discussion}

4.1 On the structure of $\mathrm{SiO}_{2}$ in the $\mathrm{P}$ (EMA-co-HEA) polymeric matrix

4.2 Characterization of $\mathrm{P}(\mathrm{EMA}-\mathrm{co}-\mathrm{HEA}) / \mathrm{SiO}_{2}$ nanocomposites

4.3 Bioactivity of $\mathrm{P}$ (EMA-co-HEA)/ $\mathrm{SiO}_{2}$ nanocomposites

4.3.1 On the morphology and composition of the apatite formed on the substrates in $\mathrm{SBF}$

4.3.2 On the structural changes of the nanohybrids when immersed in SBF

4.4 Surface treatments as a means of reducing the apatite nucleation induction times

4.5 $\mathrm{P}$ (EMA-co-HEA)/ $\mathrm{SiO}_{2}$ scaffolds mimicking natural dentin structure: structure, characterization and bioactivity

5. Conclusions

6. Appendix: Biological response 129

6.1 Culture in vitro 129

6.2 Subcutaneous implants in vivo 132

References 



\section{Abstract}

Organic/inorganic bulk nanocomposites of poly(ethyl methacrylate- $c 0$ hydroxyethyl acrylate) 70/30 wt\%/silica, $\mathrm{P}(\mathrm{EMA}-c o-\mathrm{HEA}) / \mathrm{SiO}_{2}$, were obtained with varying proportions of silica up to $30 \mathrm{wt} \%$. The synthesis procedure consisted in the copolymerization of the organic monomers EMA and HEA during the simultaneous acid-catalyzed sol-gel polymerization of tetraethoxysilane, TEOS, as silica precursor.

The structure of $\mathrm{SiO}_{2}$ in the $\mathrm{P}(\mathrm{EMA}-$ co-HEA) polymeric matrix was inferred from infrared spectroscopy, energy dispersive X-ray spectroscopy, thermogravimetry, pyrolysis, transmission electron microscopy and swelling measurements. TEOS was efficiently hydrolyzed and condensed to silica during the sol-gel process, and presented a homogeneous distribution in the polymeric matrix, in the form of disconnected aggregates of elementary silica nanoparticles in the hybrids with low silica contents $(\leq 10 \mathrm{wt} \%)$ or continuous network interpenetrated with the organic network after coalescence of these silica aggregates (> $10 \mathrm{wt} \%$ ). The small size of the silica aggregates explained the optical transparency of the obtained nanohybrids. The organic polymeric network occurred in the pores left within the elementary silica nanoparticles produced by the liquids acting as a template in the sol-gel polymerization, and those left between the aggregates of silica nanoparticles. Heterocondensation reactions between silica and the organic copolymer, if any, were negligible.

The physico-chemical properties of the hybrids were studied by density assessments and differential scanning calorimetry, the surfaces were featured by contact angle measurements, and the mechanical properties were analyzed by dynamic-mechanical analyses and compression tests. Intermediate silica contents (10-20 wt\%) exhibited the most interesting balanced properties: i) mechanical reinforcement of the glassy organic matrix attained by continuous interpenetrated silica networks, ii) good swelling ability due to the organic network expansion still 
not hindered by a rigid silica skeleton and to the relatively high number of hydrophilic boundary silanol groups (inorganic concentrations close to coalescence), and iii) enhanced surface reactivity or hydrophilicity due to the still elevated relative content of polar silanol terminal groups available at the surfaces.

The 'bioactivity' or ability of the bulk samples to form hydroxyapatite (HAp) on their surfaces was tested in vitro by soaking them in a simulated body fluid (SBF) for different times up to 35 days, the ion concentrations, temperature and $\mathrm{pH}$ of which were adjusted to almost equal those of human blood plasma. After 7 days, the SBF solution was changed to a $2 \mathrm{xSBF}$ with periodical renovation, providing more favourable conditions for apatite coating. The composition and morphology of the apatite formed and the structural changes taking place in the nanohybrids when immersed in SBF were analyzed. The formation of the apatite layer was controlled by the mechanism and induction time of the nucleation, which depended in turn on the structure of silica. In the nanohybrids with intermediate silica contents, the dissolution of silica at the surface was facilitated by the relatively large number of silanol groups, rendering an interface layer rich in silanol groups bounding a reaction zone depleted of silica. In this reaction zone calcium and phosphate ions were adsorbed and interacted with the polar silanol groups to form calcium phosphates. The apatite growth continued at the interface hybridsolution leading to a strongly adhered apatite layer. After 5 days, the growth of the apatite layer and formation of successive ones occurred very rapidly, consuming calcium and phosphate ions from the SBF. The initially amorphous calcium phosphate, containing other ions such as $\mathrm{CO}_{3}{ }^{2-}, \mathrm{Na}^{+}, \mathrm{K}^{+}$or $\mathrm{Mg}^{2+}$, stabilized leading to low-crystalline needle-shaped polycrystals of calcium-deficient carbonatedhydroxyapatite, with $\mathrm{Ca} / \mathrm{P}$ ratios close to the physiological HAp ratio.

A surface modification treatment was applied with the purpose of reducing the induction time for apatite nucleation, combining a $\mathrm{NaOH}$ attack to increase the number of surface nucleating sites, and an alternate soaking process in $\mathrm{Ca}$ and $\mathrm{P}$ solutions to form apatite precursors prior to the immersion in SBF (CaP treatment). The $\mathrm{NaOH}$ treatment was not effective by itself in shortening the HAp nucleation induction time. It introduced sodium carboxylates in the copolymer but hydrolyzed the silica network excessively, thus eliminating the silanols nucleating potential. Bioactivity was only due to the carboxylate groups of the organic phase. 
Maybe a suitable dissolution extent of the silica network so as to improve bioactivity could be attained by controlling the duration of the $\mathrm{NaOH}$ treatment. This would be interesting in the nanohybrids with superpercolating silica concentrations, where the density and continuity of the silica network with fewer silanol terminal groups hinder the polymer network swelling, the silica hydrolysis and the diffusion of ions from the SBF. Thus, at these silica concentrations, the bioactivity of the nanohybrids is only due to the preexisting HAp nucleating functional groups available at the surface. The posterior CaP treatment was able to coat the surfaces of the different samples with a calcium phosphate layer within minutes. These amorphous calcium phosphates acted as HAp precursors, skipping the induction period in SBF.

The simplicity of the synthesis procedure offers the possibility of controlling the architecture of the obtained nanocomposites. Nanohybrid tubular pores scaffolds with silica contents up to $20 \mathrm{wt} \%$ could be prepared by polymerization in a fibres template, aiming to mimic the structure and properties of the extracellular mineralized matrix of natural dentin. Although some synthetic scaffolds have been proposed as alternative tooth therapies to induce the regeneration of dentin/pulp tissues, this is, up to our knowledge, the first time a bioactive synthetic scaffold mimicking natural dentin is proposed. Intermediate percentages of silica resulted in scaffolds with mechanical properties compatible with the application while conferred bioactivity to the surfaces. This is expected to facilitate the integration in the host mineralized tissue and stimulate the differentiation of pulpal cells and the invasion of the tubules by new odontoblast prolongations when implanted in vivo, thereby guiding dentin tissue regeneration.

Keywords: Nanocomposite, hybrid, hard tissue repair, ethyl methacrylate, hydroxyethyl acrylate, tetraethyl orthosilicate, silica, solgel, bioactive, hydroxyapatite (HAp), simulated body fluid (SBF), scaffold, dentin. 



\section{Resumen}

Se sintetizaron nanocompuestos híbridos orgánico/inorgánico en bloque de poli(etil metacrilato-co-hidroxietil acrilato) 70/30 wt\%/sílice, P(EMA-co$\mathrm{HEA}) / \mathrm{SiO}_{2}$, con distintas proporciones de sílice hasta el $30 \mathrm{wt} \%$. El procedimiento de síntesis consistió en la copolimerización de los monómeros orgánicos EMA y HEA durante la polimerización sol-gel simultánea catalizada por ácido, de tetraetoxisilano, TEOS, como precursor de sílice.

La estructura del $\mathrm{SiO}_{2}$ en la matriz polimérica de $\mathrm{P}$ (EMA-co-HEA) fue deducida a partir de espectroscopía de infrarrojos, espectroscopía de energía dispersiva de rayos $\mathrm{X}$, termogravimetría, pirólisis, microscopía electrónica de transmisión e hinchado en solventes. El TEOS se hidroliza eficientemente y condensa dando lugar a sílice durante el proceso sol-gel, y presenta una distribución homogénea en la matriz polimérica, en forma de agregados inconexos de nanopartículas de sílice elementales en los híbridos con bajos contenidos de sílice ( $\leq$ $10 \mathrm{wt} \%$ ) o redes continuas interpenetradas con la red orgánica tras la coalescencia de los agregados de sílice (> $10 \mathrm{wt} \%)$. El pequeño tamaño de los agregados de sílice explica la transparencia óptica de los nanohíbridos obtenidos. La red polimérica orgánica se forma en los poros producidos en el interior de las nanopartículas elementales de sílice, debido a los líquidos que actúan como plantilla en la polimerización sol-gel, y también en los poros formados entre los agregados de nanopartículas de sílice. Si se producen reacciones de heterocondensación entre la sílice y el copolímero orgánico, éstas se pueden considerar despreciables.

Las propiedades fisicoquímicas de los híbridos fueron estudiadas a través de ensayos de densidad y calorimetría diferencial de barrido; las superficies fueron caracterizadas mediante ensayos de ángulo de contacto, y las propiedades mecánicas fueron analizadas por análisis dinámico-mecánicos y ensayos a compresión. Los nanohíbridos con contenidos de sílice intermedios (10-20 wt\%) exhibieron las propiedades más equilibradas e interesantes: i) refuerzo mecánico de 
la matriz orgánica vítrea conseguida gracias a redes de sílice continuas e interpenetradas, ii) buena capacidad de hinchado debida a la expansión de la red orgánica no impedida todavía por un esqueleto de sílice rígido, y a un número relativamente alto de grupos silanol terminales hidrófilos (concentraciones inorgánicas en los alrededores de la coalescencia), y iii) mayor reactividad superficial o hidrofilicidad debido a un contenido relativo bastante elevado de grupos polares silanol terminales disponibles en las superficies.

La 'bioactividad' o capacidad de los materiales en bloque de formar hidroxiapatita (HAp) sobre sus superficies fue estudiada in vitro sumergiéndolos en fluido biológico simulado (simulated body fluid, SBF) durante distintos tiempos hasta 35 días, ajustando las concentraciones de iones, temperatura y pH a los del plasma sanguíneo. Tras 7 días, la solución SBF fue cambiada por otra 2xSBF (el doble de concentración de iones) con renovación periódica, consiguiendo de esta manera condiciones más favorables para el recubrimiento de HAp. Se analizó la composición y la morfología de la apatita formada, así como los cambios estructurales que tienen lugar en los nanohíbridos al sumergirlos en SBF. La formación de la capa de HAp viene controlada por el mecanismo y el tiempo de inducción a la nucleación de la misma, que dependen a su vez de la estructura de la sílice. En los nanohíbridos con contenidos de sílice intermedios, el número relativamente grande de grupos silanol facilitan la disolución de sílice en la superficie, dando lugar a una interfase rica en grupos silanol delimitando una zona de reacción sin sílice. En esta zona de reacción, los iones calcio y fosfato son adsorbidos e interaccionan con los grupos polares silanol para formar fosfato cálcico. El crecimiento de apatita continúa en la interfase híbrido-solución, dando lugar a una capa de HAp fuertemente adherida. Tras 5 días, el crecimiento de la capa de apatita y la formación de las capas sucesivas tienen lugar muy rápidamente, consumiendo iones calcio y fosfato del SBF. El fosfato cálcico,

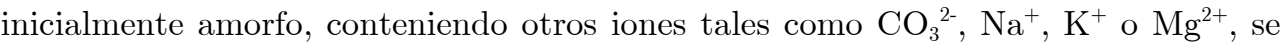
estabiliza dando lugar a policristales de baja cristalinidad con la forma de aguja típica de HAp carbonatada y deficiente en calcio, con relaciones atómicas $\mathrm{Ca} / \mathrm{P}$ cercanas a la de la HAp fisiológica.

Posteriormente se aplicó un tratamiento de modificación superficial con el objetivo de reducir el tiempo de inducción para la nucleación de HAp, que consiste 
en un ataque previo con $\mathrm{NaOH}$ para aumentar el número de puntos superficiales nucleadores, y un proceso de inmersión alternado en soluciones de calcio y fósforo (tratamiento $\mathrm{CaP}$ ) para formar los precursores de apatita previamente a la inmersión en SBF. El tratamiento con $\mathrm{NaOH}$ no resultó ser efectivo en sí mismo para acortar el tiempo de inducción a la nucleación de HAp. Este proceso introduce carboxilatos de sodio en el copolímero pero hidroliza la red de sílice excesivamente, eliminando el potencial nucleador de los grupos silanol. La bioactividad de los nanohíbridos tratados con $\mathrm{NaOH}$ se debe, pues, solamente a los grupos carboxilato de la fase orgánica. Posiblemente controlando la duración del tratamiento con $\mathrm{NaOH}$ se podría conseguir el grado de disolución de la red de sílice conveniente para aumentar la bioactividad. Esto sería interesante en los nanohíbridos con concentraciones de sílice superiores a la de percolación, donde la densidad y la continuidad de la red de sílice con menos grupos terminales dificulta el hinchado de la red de polímero, la hidrólisis de la sílice y la difusión de iones del SBF. Así, la bioactividad de los nanohíbridos con estas concentraciones de sílice se debe exclusivamente a los grupos funcionales nucleadores de HAp preexistentes en la superficie. El tratamiento posterior $\mathrm{CaP}$ permite recubrir las superficies de las distintas muestras con una capa de fosfato cálcico en minutos. El fosfato cálcico amorfo formado actúa como precursor de HAp, eludiendo el tiempo de nucleación al sumergir las muestras en SBF.

La simplicidad del procedimiento de síntesis ofrece la posibilidad de controlar la arquitectura de los nanocompuestos obtenidos. Así, se obtuvieron andamiajes (scaffolds) de poros tubulares de estos nanohíbridos, con contenidos de sílice de hasta el $20 \mathrm{wt} \%$, por polimerización en una plantilla de fibras, tratando de mimetizar de esta manera la estructura y propiedades de la matriz extracelular mineralizada de la dentina natural. Aunque en los últimos años se han propuesto algunos scaffolds sintéticos como terapias dentales alternativas para inducir la regeneración de tejidos dentinarios/pulpares, es la primera vez que, para nuestro conocimiento, se propone un scaffold sintético bioactivo que mimetiza la dentina natural. Porcentajes intermedios de sílice dan lugar a scaffolds con propiedades mecánicas compatibles con la aplicación al tiempo que le confieren bioactividad a las superficies. Es de esperar que esto facilite la integración de los scaffolds en el tejido mineralizado receptor y que estimule la diferenciación de las células pulpares 
Resumen

y la invasión de los túbulos por nuevas prolongaciones odontoblásticas al implantarlos in vivo, guiando de esta manera la regeneración del tejido dentinario.

Palabras clave: Nanocompuesto, híbrido, regeneración de tejido mineralizado, etil metacrilato, hidroxietil acrilato, tetraetil ortosilicato, sílice, sol-gel, bioactivo, hidroxiapatita (HAp), fluido biológico simulado (SBF), andamiaje (scaffold), dentina. 


\section{Resum}

En aquest treball es sintetitzaren materials nanocompostos híbrids orgànic/inorgànic en bloc de poli(etil metacrilat-co-hidroxietil acrilat) 70/30 wt\%/sílice, $\mathrm{P}$ (EMA-co-HEA)/ $/ \mathrm{SiO}_{2}$, amb distintes proporcions de sílice fins el 30 wt\%. El procediment de síntesi consistí en la copolimerització dels monòmers orgànics EMA i HEA durant la polimerització sol-gel simultània catalitzada amb àcid del tetraetoxisilà, TEOS, com a precursor de la sílice.

L'estructura del $\mathrm{SiO}_{2}$ en la matriu polimèrica de $\mathrm{P}($ EMA-co-HEA) es deduí a partir de l'espectroscopia d'infrarrojos, espectroscopia d'energia dispersiva de raigs $\mathrm{X}$, termogravimetria, piròl.lisi, microscopia electrònica de transmissió i inflat en solvents. El TEOS s'hidrolitza eficientment i condensa donant lloc a la sílice durant el procés sol-gel, i presenta una distribució homogènia en la matriu polimèrica, en forma d'agregats inconnexos de nanopartícules de sílice elementals en els híbrids amb baixos continguts de sílice $(\leq 10 \mathrm{wt} \%$ ) o xarxes contínues interpenetrades amb la xarxa orgànica després de la coalescència dels agregats de sílice $(>10 \mathrm{wt} \%)$. El xicotet tamany dels agregats de sílice explica la transparència òptica dels nanohíbrids obtinguts. La xarxa polimèrica orgànica es forma als porus produïts a l'interior de les nanopartícules elementals de sílice, degut als líquids que actuen com a plantilla en la polimerització sol-gel, i també en los porus formats entre els agregats de nanopartícules de sílice. Si es produeixen reaccions d'heterocondensació entre la sílice i el copolímer orgànic, aquestes poden considerar-se menyspreables.

Les propietats fisicoquímiques dels híbrids foren estudiades mitjançant assajos de densitat i corbes calorimètriques; les superfícies foren caracteritzades mitjançant assajos d'angle de contacte, i les propietats mecàniques foren analitzades per anàlisi dinàmic-mecànics i assajos a compressió. Els nanohíbrids amb continguts de sílice intermitjos (10-20 wt\%) exhibiren les propietats més equilibrades i interessants: i) reforç mecànic de la matriu orgànica vítria 
aconseguida gràcies a xarxes de sílice continues i interpenetrades, ii) bona capacitat d'inflat deguda a l'expansió de la xarxa orgànica encara no impedida per un esquelet de sílice rígid, i un nombre relativament alt de grups silanol terminals hidròfils (concentracions inorgàniques en els voltants de la coalescència), i iii) major reactivitat superficial o hidrofilicitat deguda a un contingut relatiu prou elevat de grups polars silanol terminals disponibles en les superfícies.

La 'bioactivitat' o capacitat dels materials en bloc de formar hidroxiapatita (HAp) sobre les seues superfícies fou estudiada in vitro submergint-los en fluid biològic simulat (simulated body fluid, SBF) durant distints temps fins 35 dies, ajustant les concentracions d'ions, temperatura i $\mathrm{pH}$ als del plasma sanguini. Després de 7 dies, la solució SBF fou canviada per una altra 2xSBF (amb el doble de concentració d'ions) amb renovació periòdica, aconseguint d'aquesta manera condicions més favorables per al recobriment de HAp. S'analitzaren la composició i la morfologia de l'HAp, així com el canvis estructurals que es produïren als nanohíbrids al submergir-los en SBF. La formació de la capa d'HAp està controlada pel mecanisme i el temps d'inducció a la seua nucleació, que depenen a la seua vegada de l'estructura de la sílice. Als nanohíbrids amb continguts de sílice intermitjos, el nombre relativament gran de grups silanol faciliten la dissolució de sílice en la superfície, donant lloc a una interfase rica en grups silanol delimitant una zona de reacció sense sílice. En aquesta zona de reacció, els ions calci i fosfat són adsorbits i interaccionen amb els grups polars silanol per a formar fosfat càlcic. El creiximent d'HAp continua en la interfase híbrid-solució, resultant en una capa d'HAp fortament adherida. Després de 5 dies, el creiximent de la capa de HAp i la formació de les capes successives es produeixen molt ràpidament, consumint ions calci i fosfat de l'SBF. El fosfat càlcic, inicialment amorf, i contenint altres ions com ara $\mathrm{CO}_{3}{ }^{2-}, \mathrm{Na}^{+}, \mathrm{K}^{+} \mathrm{o} \mathrm{Mg}^{2+}$, s'estabilitza donant lloc a policristalls de baixa cristal-linitat amb la forma d'agulla típica d'HAp carbonatada i deficient en calci, $\mathrm{amb}$ relacions atòmiques $\mathrm{Ca} / \mathrm{P}$ pròximes a la de l'HAp fisiològica.

Posteriorment s'aplicà un tractament de modificació superficial amb l'objectiu de reduir el temps d'inducció per a la nucleació d'HAp, que consistí en un atac previ amb $\mathrm{NaOH}$ per augmentar el nombre de punts superficials nucleadors, i un procés d'immersió alternat en solucions de calci i fòsfor (tractament $\mathrm{CaP}$ ) per a formar els precursors d'apatita prèviament a la immersió en SBF. El tractament 
amb $\mathrm{NaOH}$ no resultà ser efectiu per ell mateix en acurtar el temps d'inducció a la nucleació d'HAp. Aquest procés introdueix carboxilats de sodi en el copolímer però hidrolitza la xarxa de sílice excessivament, eliminant el potencial nucleador dels grups silanol. La bioactivitat dels nanohíbrids tractacts amb $\mathrm{NaOH}$ es deu, doncs, solament als grups carboxilat de la fase orgànica. Possiblement controlant la duració del tractament amb $\mathrm{NaOH}$ es podria aconseguir el grau de dissolució de la xarxa de sílice convenient per a augmentar la bioactivitat. Açò seria interessant en els nanohíbrids amb concentracions de sílice superiors a la de percolació, on la densitat i la continuïtat de la xarxa de sílice amb menys grups terminals dificulta l'inflat de la xarxa de polímer, l'hidròlisi de la sílice i la difusió d'ions de l'SBF. Així, la bioactivitat dels nanohíbrids amb estes concentracions de sílice es deu exclusivament als grups funcionals nucleadors d'HAp preexistents en la superfície. El tractament posterior $\mathrm{CaP}$ permet recobrir les superfícies de les distintes mostres amb una capa de fosfat càlcic en minuts. El fosfat càlcic amorf format actua com a precursor d'HAp, eludint el temps de nucleació al submergir les mostres en SBF.

La simplicitat del procediment de síntesi ofereix la possibilitat de controlar l'arquitectura dels nanocompostos obtinguts. Així, s'obtingueren bastiments (scaffolds) de porus tubulars d'aquestos nanohíbrids, amb continguts de sílice de fins el $20 \mathrm{wt} \%$, per polimerització en una plantilla de fibres, tractant de mimetitzar d'aquesta manera l'estructura i propietats de la matriu extracel-lular mineralitzada de la dentina natural. Encara que durant els últims anys s'han proposat alguns bastiments sintètics com a teràpies dentals alternatives per a induir la regeneració de teixits dentinaris/polpars, aquesta és la primera vegada que es proposa un bastiment sintètic bioactiu que mimetitza la dentina natural. Percentatges intermitjos de sílice donen lloc a bastiments amb propietats mecàniques compatibles amb l'aplicació al temps que li confereixen bioactivitat a les superfícies. És d'esperar que açò facilite la integració dels bastiments en el teixit mineralitzat receptor i que estimule la diferenciació de les cèl-lules polpars i la invasió dels túbuls per noves prolongacions odontoblàstiques al implantar-los in vivo, guiant d'aquesta manera la regeneració del teixit dentinari.

Paraules clau: Nanocompost, híbrid, regeneració de teixit mineralitzat, etil metacrilat, hidroxietil acrilat, tetraetil ortosilicat, sílice, sol-gel, 
Resum

bioactiu, hidroxiapatita (HAp), fluid biològic simulat ( $\mathrm{SBF}$ ), bastiment (scaffold), dentina. 


\section{Chapter 1}

\section{Introduction}

\subsection{Dentin}

\subsubsection{Structure and composition}

Teeth consist of a crown surface for mastication and roots anchoring the tooth to underlying alveolar bone via the periodontal ligament, Figure 1.1 (left). The tooth crown is covered by the highly mineralized enamel. Tooth roots are covered by bone-like mineralized cementum. Dentin is the mineralized tissue beneath enamel and cementum that constitutes the body of teeth. It provides a covering for the pulp and serves as a support for the overlying highly mineralized enamel while compensates for its brittle nature. Without the support of the dentin structure, enamel would fracture when exposed to the forces of mastication. The primary function of dentin is thus mechanical. The pulp is a loose connective tissue centrally located that provides dentinogenic, nutritive, sensory, and defensive functions to the tooth. 


\section{Introduction}

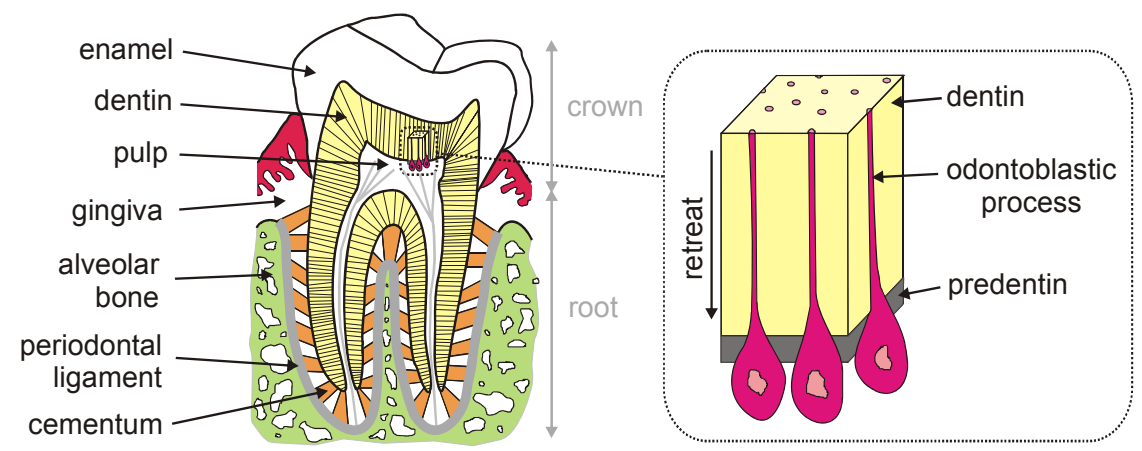

Figure 1.1 Diagram of a tooth cut in cross section.

One of the morphological features of dentin is the presence of small tubules of few microns, which traverse it from the pulp chamber to the region just below the dentin-enamel junction, Figure 1.1 (right) and Figure 1.2. Tubule density and orientation depend on the location. The percentages of tubule area and tubule diameter vary from $1 \%$ and $0.9 \mu \mathrm{m}$ near the dentin-enamel junction to $22 \%$ and 2.5 $\mu \mathrm{m}$ near the pulp ${ }^{[1]}$. Each tubule contains the apical prolongation of one odontoblast ${ }^{[1,2]}$. The odontoblast cell bodies are located at the inner edge of the tubules forming the peripheral boundary of the pulp ${ }^{[3]}$.

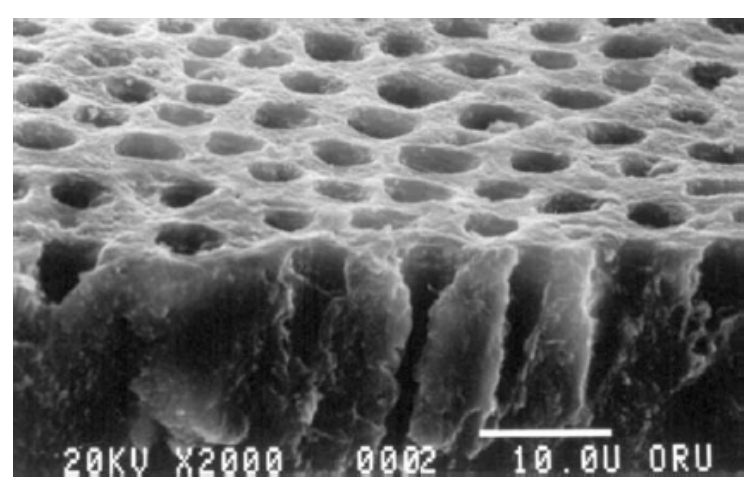

Figure 1.2 Scanning electron micrograph of a dentin sample [reproduced from [1], with permission]. 
Dentin is a composite structure composed of approximately a $30 \mathrm{vol} \%$ of an organic matrix, consisting mostly of type I collagen, a $50 \mathrm{vol} \%$ of an inorganic reinforcing phase of carbonated apatite and a 20 vol\% of dentinal fluid similar to blood plasma [4]. The mineral constituent of dentin is a carbonate-rich calcium-deficient hydroxyapatite (HAp). Mineral HAp $\left(\mathrm{Ca}_{5}\left(\mathrm{PO}_{4}\right)_{3} \mathrm{OH}\right.$, often written as $\mathrm{Ca}_{10}\left(\mathrm{PO}_{4}\right)_{6}(\mathrm{OH})_{2}$ to show that there are two formula units in the crystallographic unit cell, Figure 1.3) is generally considered as a model compound for biological mineralization. This ideal formula is never actually found; there are always, though, some chemical and structural differences ${ }^{[5]}$.

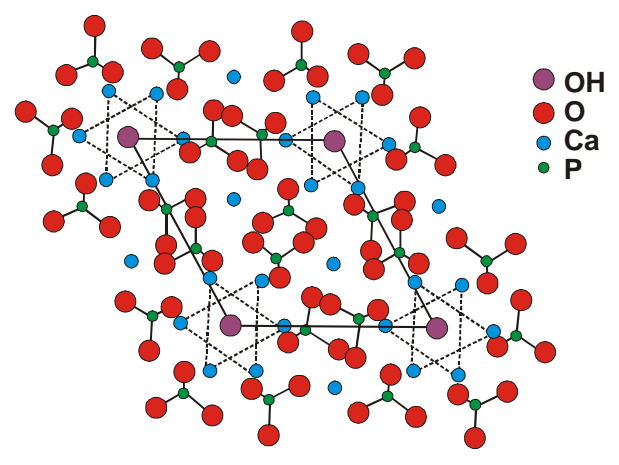

Figure 1.3 Sketch of the HAp structure (x,y projection), 4 unit cells. Each cell shows 6 tetrahedral sites for $\mathrm{PO}_{4}$ ionic groups, 4 sites for $\mathrm{Ca}$ ions and 6 other sites for $\mathrm{Ca}$ ions forming a channel along the c-axis, which is occupied by the $\mathrm{OH}$ ions. These channels are oriented perpendicular to the page ${ }^{[5]}$.

The composition of the peritubular dentin surrounding the pores is carbonate apatite with very small amounts of organic matrix, whereas intertubular dentin separating the tubules is type I collagen matrix reinforced with apatite. Mineralized collagen fibrils are perpendicular to the tubules and consist in a collagen framework and thin-plate shaped carbonate apatite crystals, whose c-axes are aligned with the collagen fibril axis. The ratio of intertubular to peritubular dentin decreases from the dentin-enamel junction to the pulp. The mineral crystallites are more plate-like 


\section{Introduction}

near the dentin-enamel junction and needle-like in the recently formed dentin near the pulp, with an average thickness of $5 \mathrm{~nm}{ }^{[6]}$.

The structure of enamel consists of a tightly packed mass of hydroxyapatite crystals which are organized in highly oriented patterns (enamel prisms or rod-like structures radiating from the dentin-enamel junction perpendicularly to the surface). It is $95-98 \%$ mineralized; it is not, thus, a living tissue and consequently it does not regenerate ${ }^{[7]}$.

The pulp is divided into a coronal pulp chamber and a radicular root canal. The principal cells of the pulp are the odontoblasts, fibroblasts, mesenchymal cells and cells of connective tissue related to the neural, vascular and immune systems. The pulp is highly innervated: vessels enter into the pulp through the apical foramina [7].

\subsubsection{Dentinogenesis and dentinogenic responses to injury}

During tooth development ${ }^{[1,8]}$, specialized dental epithelial cells called ameloblasts produce the enamel, whereas inductive epithelial-mesenchymal interactions lead to the differentiation of ectomesenchymal pulp cells into odontoblasts. Dentin is deposited by these post-mitotic odontoblasts. The formation of primary dentin by mature odontoblasts begins at the dentin-enamel junction and involves secretion of matrix proteins at the apical portion of the cell and along its process. The tissue formed directly outside the odontoblasts, termed the predentin, consists largely of type I collagen fibrils and certain proteoglycans. The non-collagenous proteins secreted into the extracellular matrix during dentinogenesis include dentin sialophosphoprotein, dentin matrix protein-1, and matrix extracellular phosphoglycoprotein. Several signaling molecules such as transforming growth factor beta (TGF- $\beta$ ), bone morphogenetic proteins (BMPs) and fibroblast growth factors (FGFs) can also be found ${ }^{[9]}$. As the dimensions of the predentin matrix grow, the cells recede in the pulpal direction leaving behind odontoblastic 
processes, which extend in the dentinal tubules forming a collagenous scaffold. At a specific location (predentin-dentin junction or mineralization front), the collagenous fibrilar network acquires mineral and the predentin tissue is converted to dentin. Dentin mineralization starts with globular aggregations of apatite crystals appearing along or within the collagenous fibrils, perpendicular to the dentinal tubules and parallel with the mineralization growth front ${ }^{[6]}$. The precise mechanism of dentin mineralization is not well defined, but non-collagenous proteins at the mineralization front seem to be involved. The decrease in dentin phosphoprotein phosphorylation has been found to lead to the reduction of $\mathrm{Ca}^{2+}$ binding abilities and ultimately to hypomineralization of dentin ${ }^{[10]}$. The formed mineralized nuclei progressively grow and merge converting predentin fibrils into a mineralized matrix. This process leaves finally the aforementioned structure of Figure 1.1.

Enamel exhibits no regenerative capacity, because progenitor dental epithelial cells that form enamel lose their ability well before tooth eruption ${ }^{[11]}$. Odontoblasts, as highly differentiated cells, have lost the ability for mitosis and self-reproduction ${ }^{[12]}$, but as they can be stimulated to deposit more dentin, this tissue is capable of a limited repair ${ }^{[1,3]}$. Besides, the number of pulp progenitor/stem cells in a permanent tooth is not large enough for tooth regeneration ${ }^{[13]}$. Consequently, dentin does not remodel continuously as occurs in bone, but responds to injuries by forming some kind of dentin to protect the dental pulp ${ }^{[14]}$.

Physiological or secondary dentin is deposited at a very much slower rate for the biological life of the tooth by normal physiologic stimuli and enamel abrasion, and results in gradual narrowing of the pulp chamber. After primary dentinogenesis, the odontoblasts go into a dormant state, so the limited secondary dentin formation during the life of the tooth represents a basal level of activity. Tertiary, reparative or reactionary dentin, forms as a focal deposition in response to pathologic processes or abrasion, in order to act as a barrier and increase the distance between the injury and the pulpal cells. The composition and structure of altered dentin differs from those of natural dentin. It has less regular structure with fewer and less well-aligned tubules. Reparative dentin is formed by new odontoblastic cells and implies discontinuity in tubular structure and reduction in 


\section{Introduction}

permeability, whereas reactionary dentin is formed by survival odontoblasts, so there will be tubular continuity ${ }^{[1,15,16]}$.

Mild injuries stimulate the surviving odontoblasts at the site of the injury to upregulate their synthetic and secretory activities to secrete a reactionary dentin. Growth factors and signalling molecules (similar to those involved in physiological dentinogenesis) promote the increased activities of odontoblasts. In pathological conditions that cause odontoblast death, the reparative dentin secretion is carried out by a new generation of odontoblast-like cells. Reparative dentinogenesis is a more complex sequence of biological processes, depending on the presence of progenitor cells and inductive molecular signals for induction of proliferation, migration and differentiation of a new generation of odontoblasts ${ }^{[17]}$. The dental pulp has stem cells able to differentiate into dentin-forming odontoblasts in response to BMPs. When dental pulp tissue is injured and damaged odontoblasts degenerate, then these undifferentiated cells can migrate to the injured site from the deeper regions of the pulp tissue ${ }^{[18]}$. Reparative dentin is formed towards the root and the remaining pulp becomes smaller. The ability of both young and old teeth to respond to injury by inducing reparative dentin suggests that a small population of competent progenitor pulp stem cells exist within the dental pulp $[17,19]$.

\subsubsection{Dentin/pulp therapies}

Dentin can be exposed to oral diseases, chemical-physical injuries (trauma, exogenous or endogenous substances), as well as to alterations due to imperfections occurring while being formed ${ }^{[20]}$. Although there are other oral lesions, caries is the most common dental problem by which the dentin matrix is damaged. The procedure usually followed is direct pulp capping with calcium hydroxide for sterilizing the area. Besides its antibacterial effects, calcium hydroxide seems to extract growth factors from the dentin matrix, which may play key roles in signalling many of the events of tertiary dentinogenesis ${ }^{[15,19]}$. When caries is deep and pulp is exposed, root canal therapy is necessary. This technique involves the 
removal of the pulp tissue to avoid an inflammation reaction and preserve the surrounding tissues for not losing the tooth. The second part of both treatments implies the replacement of the affected dental tissue by synthetic filling composites (or artificial prosthesis) and sealing it up to minimize the possibility of bacterial recolonization and avoid tissue fluids to seep inside the tooth ${ }^{[2,18]}$. For mediumsized defects, the currently used commercial restorative composites contain a mixture of various crosslinking dimethacrylates, glass- and/or silicon dioxide fillers, and a photoinitiator system. For larger defects, prefabricated ceramic restorations are attached to the tooth structure with composite-based cements in combination with adhesives ${ }^{[21]}$. Few of these materials share the same physical or chemical characteristics of the natural replaced tissue, and these cavity restorations tend to fail mechanically. Besides, microleakage of the composite/tooth interface with the penetration of bacterial enzymes, bacteria, fluids and ions tend to produce hypersensitivity and secondary caries ${ }^{[1,18]}$.

The ultimate goal in dental therapies would be to maintain not only structure but also vitality and function of the dentin-pulp complex, by removing the diseased or necrotic tissue, stimulating specific dentinogenic response, and restoring the cavity with healthy tissue to revitalize teeth.

\subsubsection{Tissue engineering applied to the regeneration of pulp and dentin in endodontics}

Langer and Vacanti ${ }^{[22]}$ defined the tissue engineering as an interdisciplinary field that applies the principles of engineering and life sciences toward the development of biological substitutes that restore, maintain or improve tissue function. The reconstruction of a living tissue is usually achieved by implantation of threedimensional natural or synthetic scaffolds at the defective sites. They provide frameworks for cells to attach, proliferate, and form extracellular matrix (ECM). They should exhibit biocompatibility, nontoxicity and appropriate physical and mechanical strength. Scaffolds are sometimes seeded with appropriate living cells. These cells must develop, organize, and behave as if they were in their native 


\section{Introduction}

tissue. The attachment, proliferation and differentiation of the cells is usually induced by the addition of ligands for adhesion of receptors of the cells, growth factors or their functional activators, hormones, enzymes and other regulators of cell behaviour, and other ECM components ${ }^{[23,24]}$.

Given the complexity of the tooth structure and the fact that the spatial pattern of dentinogenesis takes place through the pulpal direction whereas tissue loss occurs from the opposite direction ${ }^{[17]}$, complete tooth regeneration is a difficult task. In the last years, three different tissue engineering therapies to restore partial dental structures have been proposed, based on the regenerative capacity of dental/pulp tissue, alternative to the conventional irreversible endodontic treatments (pulp capping or root canal therapy) ${ }^{[2,11,18,19,25-27]}$. Two of these therapies are based on the stimuli for the differentiation of pulpal progenitor cells to odontoblasts ${ }^{[18]}$. They focus on: $i$ ) enhancing the natural healing potential of pulp tissue by application of BMPs, and ii) ex vivo isolation of stem cells, differentiation and transplantation, when there is severe inflammation and few stem cells in the dental pulp. The third therapy aims at iii) inducing the regeneration of tooth structures by means of (cell/)scaffold constructs where the prefabricated natural or synthetic scaffold works as extracellular matrix for adhesion, proliferation and differentiation of cells ${ }^{[18,19]}$. Growth factors such as transforming growth factor TGF- $\beta 1^{[27]}$ are sometimes included in the construct to induce new odontoblast-like cell differentiation from pulpal progenitor cells. Here we relate different strategies that address this third tissue engineering therapy in order to give idea of the state of the art, since it is in this scope that this thesis is framed.

Buurma et al. ${ }^{[26]}$ implanted nonwoven polyglycolic acid (PGA) fiber scaffolds, previously seeded with human dental pulp fibroblasts (HPF) and in vitro cultured, into subcutaneous sites in immunocompromised mice. They found that these HPF survived and synthesized type I collagen, cellular fibronectin and expressed genes implicated in transducing BMP signals. Young et al. ${ }^{[25]}$ and Yelick et al. ${ }^{[11]}$ seeded different spongeous biodegradable scaffolds of polylactic (PLLA) and polyglycolic (PGA) acids with cell suspensions obtained from dissociated porcine tooth buds, and later on implanted them in the omenta of athymic rats. The scaffolds provided 
a support into which epithelial (enamel producing) and mesenchymal (dentin and pulp producing) dental cells could interact and differentiate. Their histological analyses revealed the regeneration of the two major mineralized structures of the tooth: dentin and enamel. The formation of many small tooth crowns randomly orientated instead of one large bioengineered tooth with the shape of the scaffold was attributed to the heterogeneity of tooth bud cell populations. In this context, Honda et al. ${ }^{[28]}$ hypothesized that if the contact positions between the epithelial and mesenchymal cells could be manipulated during the initiation of tooth regeneration, the tooth morphology would be regular in shape. They separated and dissociated mesenchyme and epithelium from porcine third molar teeth. They seeded mesenchymal cells onto the surface of spongeous natural collagen scaffolds (made from collagen extracted from porcine skin) and epithelial cells on top so that the two cell types were in direct contact, and implanted the cell-scaffold constructs into immunocompromised rats. After 20 weeks, the implants acquired the structural characteristics of teeth with mineralized dentin, odontoblasts lining the inner surface of the pre-dentin matrix and ameloblasts adjacent to a small amount of enamel, in contrast with abnormal shapes generated by random seeding of cells onto the scaffolds. These results indicated that direct cell-cell contacts were necessary for enamel-dentin regeneration. Bohl et al. ${ }^{[2]}$ demonstrated that PGA scaffolds were more efficient than collagen or alginate scaffolds when cultured in vitro with seeded HPF. In another approach, Young et al. ${ }^{[29]}$ prepared hybrid tooth-alveolar bone foam scaffolds of PGA and polyglycolide-co-lactide for the clinical treatment of tooth loss accompanied with alveolar bone resorption. On the one hand, tooth scaffolds of these materials were seeded with pig tooth bud cells and cultured in vivo for 10 days in the omenta of adult rat hosts; on the other, bone scaffolds were seeded with osteoblasts from bone marrow progenitor cells and grown in a bioreactor. Once harvested, the scaffolds were sutured together and reimplanted. After 8 weeks of reimplantation, the tooth-bone hybrid constructs showed primary and reparative dentin in the tooth portion, osteocalcin and bonesialoprotein-positive bone in the bone portion, and collagen type III-positive connective tissue resembling periodontal ligament and tooth root structures at the interface. 


\section{Introduction}

Among the non-biodegradable synthetic materials, those most used for preparing scaffolds have been calcium phosphates (hydroxyapatite (HAp), $\beta$-tricalcium phosphate $\left(\beta\right.$-TCP), and their derivatives). Wang et al. ${ }^{[30]}$ cultured in vitro human dental pulp cells onto calcium polyphosphate scaffolds for 14 days and found good adhesion, proliferation and spreading of the cells to the scaffolds. Many fine processes and matrix secretory granules could be seen on cell surfaces, suggesting the differentiation of the seeded cells into functional odontoblast-like cells. Zhang et al. ${ }^{[31]}$ followed the reaction of human dental pulp stem cells on different scaffold materials: a spongeous collagen, a porous sintered HAp/TCP and a fibrous titanium mesh. All of them supported the attachment, growth and differentiation of pulpal stem cells in vitro, but only little amounts of hard tissue were formed in in vivo subcutaneous experiments in immunocompromised rats, compared to those formed in similar materials but using bone marrow cells. Yoshikawa et al. ${ }^{[32]}$ decided to use bone marrow mesenchymal cells for their experiments to avoid the undesirable extirpation of autologous odontoblasts (limited by the accessibility and availability of sufficient donor tissue). They found bone formation in HAp scaffolds seeded with bone marrow cells from rat femurs after 4 weeks of in vivo subcutaneous implantation in rats, but only if the scaffolds were previously coated with hyaluronic acid, which promoted cell differentiation and bone formation in the pores. However, they did not found significant difference in bone formation with and without hyaluronic acid in in vitro monolayer cultures.

Although these therapies with spongeous or fiber scaffolds as synthetic tooth tissues show very promising results, they have several limitations: $i$ ) these materials do not exhibit mechanical or physical properties similar to natural tooth tissues, ii) the obtained scaffolds do not mimic the natural architecture of the dental structures and therefore the cellular organization when placing the scaffold at the defective site will not be the biological one, and lastly iii) there is a crucial issue that is generally not evaluated, which is the compatibility of these materials with the surrounding mineralized tissues. These issues are addressed in this work. 


\subsection{Bioactivity}

\subsubsection{Requirement for bone bonding: in vivo bioactivity}

In the previous section we related some materials that have been proposed for the stimulated regeneration of mineralized tissues like dentin. But materials aiming to be used for guided mineralized tissue regeneration need to be not only biocompatible, but also osteoconductive, preferably osteoinductive, and mechanically compatible with bone or teeth. A bioinert synthetic material is generally hosted in a tissue defect isolated from the surrounding tissue by encapsulation with non-adherent fibrous connective tissue. Biocompatibility ensures that a biomaterial is not immediately attacked by macrofages, if encapsulated by the body it is by a thin fibrous capsule, and can be used without any damage to surrounding tissues and organs as well as to the whole organism. In the regeneration of the dental mineralized tissues, chemical or physical adhesion to enamel or dentin is important in preventing recurring caries, to avoid breakdown and infiltration, and in saving the healthy tissue ${ }^{[20]}$. Rapid surface reactions in osteoinductive (or osteoproductive) materials stimulate both extracellular and intracellular (differentiation and proliferation) responses at the interface of the material with its physiological environment, giving rise to rapid in vivo bone regeneration. Slower surface reactions lead to bone migration and only extracellular responses along the interface of the so-called osteoconductive materials ${ }^{[33,34]}$.

Since the discovery of $45 \mathrm{~S} 5$ Bioglass ${ }^{\circledR}\left(24.5\right.$ wt\% $\mathrm{Na}_{2} \mathrm{O}-24.5 \mathrm{wt} \% \mathrm{CaO}-45 \mathrm{wt} \%$ $\left.\mathrm{SiO}_{2}-6 \mathrm{wt} \% \mathrm{P}_{2} \mathrm{O}_{5}\right)$ by Hench in $1971^{[33]}$, which appeared to strongly adhere to bone tissue, various kinds of ceramics such as $\mathrm{Na}_{2} \mathrm{O}-\mathrm{CaO}-\mathrm{SiO}_{2}-\mathrm{P}_{2} \mathrm{O}_{5}$ glasses, sintered hydroxyapatite and glass-ceramics containing apatite or wollastonite, are known to bond directly to living bone without the formation of fibrous tissue ${ }^{[34-38]}$. Some of them or derivatives are being clinically used in artificial middle-ear bone implants, artificial vertebrae, intervertebral discs, iliac bones, fillers in bone and maxillofacial defects or to fill the gap around the implants, etc. and have inspired 


\section{Introduction}

new bioactive materials with varied compositions and structures to fulfill different applications ${ }^{[33,34,39-47]}$. The bone-bonding biomaterials, so-called bioactive or surfaceactive, are biocompatible materials that form a layer of hydroxyapatite (HAp) similar to the apatite in bone (chemically and crystalographically) on their surface when implanted in the body, and bond to the living bone through this apatite layer. This apatite is a low-crystalline carbonate-containing calcium-deficient HAp containing other ions present in the body fluids such as sodium, magnesium, chlorine and carbonate ${ }^{[33-35,39,48]}$. On the apatite layer, osteoblasts proliferate in preference to fibroblasts, differentiating and producing an extracellular matrix (ECM) composed of biological calcium phosphate and collagen. The apatite layer establishes a tight chemical integration with bone to decrease the interfacial energy between them. On the basis of in vivo experiments, in 1991 Kokubo ${ }^{[39]}$ elucidated that the essential condition for an artificial material to bond to living bone was the in vivo formation of a bone-like apatite layer on its surface when implanted in the living body.

\subsubsection{Biomimetic in vitro test for predicting the in vivo bioactivity}

In 1991, Kokubo ${ }^{[39]}$ developed a simple biomimetic test to reproduce the formation of an apatite layer ex vivo and thereby evaluate the bioactivity of a given material. This test consists in the immersion of the samples in an acellular protein-free simulated body fluid (SBF) with ion concentrations, $\mathrm{pH}$ and temperature nearly equal to those of the human blood plasma, as the medium for apatite nucleation. Table 1.1 shows the ion concentrations of the apatite in SBF and human blood plasma. This test has been widely used for the study of biomineralization on different types of materials ${ }^{[39,40,48-53]}$, and the ability of several materials to form apatite on their surfaces has been correlated with their in vivo bioactivities ${ }^{[38]}$. This means that the in vivo bone-bonding ability of a given material can be predicted, before animal testing, from the apatite formation on its surface when subjected to this test. Usually, the apatite formed in SBF is carbonate-containing hydroxyapatite similar to bone in composition and structure, but with lower carbonate content than that in the apatite crystals formed in dentin ${ }^{[1]}$ (5.7 wt\%) 
and thus with lower $\mathrm{Ca} / \mathrm{P}$ molar ratio, which has been attributed to the lower concentration of $\mathrm{HCO}_{3}{ }^{-}$ions ${ }^{[54]}$.

\begin{tabular}{|c|c|c|c|c|c|c|c|c|c|}
\hline & \multicolumn{8}{|c|}{ Ion concentration $(\mathrm{mM})$} & \multirow[b]{2}{*}{$\log$ IP } \\
\hline & $\mathrm{Na}^{+}$ & $\mathrm{K}^{+}$ & $\mathrm{Ca}^{2+}$ & $\mathrm{Mg}^{2+}$ & $\mathrm{Cl}^{-}$ & $\mathrm{HCO}_{3}^{-}$ & $\mathrm{HPO}_{4}{ }^{2-}$ & $\mathrm{SO}_{4}{ }^{2-}$ & \\
\hline Blood plasma & 142.0 & 5.0 & 2.5 & 1.5 & 103.0 & 27.0 & 1.0 & 0.5 & -96.6 \\
\hline SBF & 142.0 & 5.0 & 2.5 & 1.5 & 148.8 & 4.2 & 1.0 & 0.5 & -96.6 \\
\hline $2 \times \mathrm{SBF}$ & 284.0 & 10.0 & 5.0 & 3.0 & 297.6 & 8.4 & 2.0 & 1.0 & -91.9 \\
\hline
\end{tabular}

Table 1.1 Ion concentrations and ionic activity products (log IP) of the apatite in simulated body fluids (SBF), twice SBF (2xSBF) and human blood plasma.

According to the following reaction:

$$
10 \mathrm{Ca}^{2+}+6 \mathrm{PO}_{4}^{3-}+2 \mathrm{OH}^{-} \rightarrow \mathrm{Ca}_{10}\left(\mathrm{PO}_{4}\right)_{6}(\mathrm{OH})_{2}
$$

the driving force for the formation of HAp from a supersaturated solution is the change in Gibbs free energy, $\Delta G$, from the initial solution, $G$, to the final solution in which HAp has been formed, $G$ :

$$
\Delta G=G^{\prime}-G=\sum_{i=1}^{4} n_{i} \hat{\mu}_{i}^{\prime}-\sum_{i=1}^{3} n_{i} \hat{\mu}_{i}=n_{4}{ }^{\prime} \hat{\mu}_{4}^{\prime}+\sum_{i=1}^{3}\left(n_{i}^{\prime}-n_{i}\right) \hat{\mu}_{i}=n_{4}{ }^{\prime} \cdot\left[\hat{\mu}_{4}{ }^{\prime}-\sum_{i=1}^{3} v_{i} \hat{\mu}_{i}\right]
$$

where components $i$ from 1 to 3 are the ions $\mathrm{Ca}^{2+}, \mathrm{PO}_{4}{ }^{3-}$ and $\mathrm{OH}^{-}$, and component 4 is solid HAp, which is present only in the final state; $n_{i}$ and $n_{i}{ }^{\prime}$ are the number of moles of each component in the initial and final solution, respectively; $\hat{\mu}_{i}$ and $\hat{\mu}_{i}{ }^{\prime}$ are the chemical potential of each component in the initial and final solution, respectively, and $v_{i}$ is the stoichiometric coefficient of each ion according to Equation 1.1. between the constituent ions of HAp (positive for reagents, negative for the product).

The chemical potential of each component in a mixture can be expressed as: 


\section{Introduction}

$$
\hat{\mu}_{i}=\mu_{i}^{s t}+R T \ln \hat{a}_{i}
$$

where $\mu_{i}^{\text {st }}$ is the standard chemical potential of the component in the reference state, $R$ is the universal gas constant, $T$ the absolute temperature, and $\hat{a}_{i}$ is the activity of the component in the mixture in the reference state. Thus,

$$
\frac{\Delta G}{n_{4}{ }^{\prime}}=\Delta g=\mu_{4}^{s t}-\sum_{i=1}^{3} v_{i}\left(\mu_{i}^{s t}+R T \ln \hat{a}_{i}\right)=-\sum_{i=1}^{4} v_{i} \mu_{i}^{s t}-R T \sum_{i=1}^{3} v_{i} \ln \hat{a}_{i}
$$

because for HAp $\hat{\mu}_{4}=\mu_{4}^{\text {st }}$.

The ionic activity product IP of the apatite in an aqueous solution is given by ${ }^{[40,54]}$ :

$$
\begin{aligned}
I P & =\left(\hat{a}_{\mathrm{Ca}^{2+}}\right)^{10} \cdot\left(\hat{a}_{\mathrm{PO}_{4}^{3-}}\right)^{6} \cdot\left(\hat{a}_{\mathrm{OH}^{-}}\right)^{2}= \\
& =\left(\hat{\gamma}_{\mathrm{Ca}^{2+}}\right)^{10} \cdot\left(\hat{\gamma}_{\mathrm{PO}_{4}^{3-}}\right)^{6} \cdot\left(\hat{\gamma}_{\mathrm{OH}^{-}}\right)^{2} \cdot\left[\mathrm{Ca}^{2+}\right]^{10} \cdot\left[\mathrm{PO}_{4}^{3-}\right]^{6} \cdot\left[\mathrm{OH}^{-}\right]^{2}
\end{aligned}
$$

where $\hat{a}_{i}$ is the activity, $\hat{\gamma}_{i}$ is the activity coefficient and [] is the molar concentration of each ion. Considering the elements concentrations and $\mathrm{pH}$, the ionic activity product IP of the apatite in a fluid can be calculated. $\hat{\gamma}_{\mathrm{Ca}^{2+}}, \hat{\gamma}_{\mathrm{PO}_{4}^{3-}}$ and $\hat{\gamma}_{\mathrm{OH}^{-}}$are $0.36,0.06$ and 0.72 , respectively, at physiological ionic strength ${ }^{[40]}$. The equilibria maintained among $\mathrm{H}_{3} \mathrm{PO}_{4}, \mathrm{H}_{2} \mathrm{PO}_{4}^{-}, \mathrm{HPO}_{4}{ }^{2-}, \mathrm{PO}_{4}{ }^{3-}$ and $\mathrm{H}^{+}$, and between $\mathrm{Ca}^{2+}$ and $\mathrm{H}_{2} \mathrm{PO}_{4}^{-}, \mathrm{HPO}_{4}{ }^{2-}$ and $\mathrm{PO}_{4}{ }^{3-}$ can also be considered:

$$
\begin{array}{cl}
\mathrm{HPO}_{4} \rightarrow \mathrm{H}^{+}+\mathrm{H}_{2} \mathrm{PO}_{4}^{-} & K_{1}=6.22 \times 10^{-3} \\
\mathrm{H}_{2} \mathrm{PO}_{4}^{-} \rightarrow \mathrm{H}^{+}+\mathrm{HPO}_{4}^{2-} & K_{2}=6.58 \times 10^{-8} \\
\mathrm{HPO}_{4}^{2-} \rightarrow \mathrm{H}^{+}+\mathrm{PO}_{4}^{3-} & K_{3}=6.61 \times 10^{-13} \\
\mathrm{Ca}^{2+}+\mathrm{H}_{2} \mathrm{PO}_{4}^{-} \rightarrow \mathrm{CaH}_{2} \mathrm{PO}_{4}^{+} & K_{4}=31.9 \\
\mathrm{Ca}^{2+}+\mathrm{HPO}_{4}^{2-} \rightarrow \mathrm{CaHPO}_{4} & K_{5}=6.81 \times 10^{2} \\
\mathrm{Ca}^{2+}+\mathrm{PO}_{4}{ }^{3-} \rightarrow \mathrm{CaPO}_{4}^{-} & K_{6}=3.46 \times 10^{6}
\end{array}
$$

where $K_{i}$ are the equilibrium constants. The activity coefficients $\hat{\gamma}_{\mathrm{H}^{+}}, \hat{\gamma}_{\mathrm{H}_{2} \mathrm{PO}_{4}^{-}}$and $\hat{\gamma}_{\mathrm{HPO}_{4}^{2-}}$ are $0.81,0.62$ and 0.23 , and $\hat{\gamma}_{\mathrm{CaH}_{2} \mathrm{PO}_{4}^{+}}$and $\hat{\gamma}_{\mathrm{CaPO}_{4}^{-}}$are assumed to be 0.72 in 
both cases ${ }^{[40]}$. The IP logarithm of the SBF solution and human blood plasma are tabulated in Table 1.1.

Besides, $\Delta g_{\text {reac }}^{s t}=-\sum_{i=1}^{4} v_{i} \mu_{i}^{R}$ is the standard free energy of the reaction, which is usually tabulated in the form of the equilibrium constant, $K_{0}$, being $K_{0}=\exp \left(\Delta g_{\text {reac }}^{\text {st }} / R T\right)$. The equilibrium constant for the formation of the hydroxyapatite (equation 1.1) $K_{0}$ is $5.5 \times 10^{-118}$ at $37^{\circ} \mathrm{C}$.

Thus, dividing by $R T$ one obtains,

$$
\frac{\Delta g}{R T}=-\frac{\sum_{i=1}^{4} v_{i} \mu_{i}^{R}}{R T}-\sum_{i=1}^{3} v_{i} \ln \hat{a}_{i}^{R}=\frac{\Delta g_{\text {reac }}^{o}}{R T}-\ln \prod_{i=1}^{3}\left(\hat{a}_{i}^{R}\right)^{v_{i}}=\ln K_{0}-\ln I P
$$

The change in Gibbs free energy per mol of HAp formed results finally ${ }^{[55,56]}$,

$$
\Delta g=-R T \ln \frac{I P}{K_{0}}=-R T \ln \Omega
$$

The rates of precipitation of slightly soluble salts from supersaturated solutions depend thus on the supersaturation ratio, $\Omega$. This degree of supersaturation of the apatite in the SBF is always much higher than unity, independently of the possible release of apatite constituent ions from the substrate to the medium.

The crystal growth rate, $R$, has been found to be proportional to the relative solution supersaturation, $\sigma$,

$$
\sigma=\Omega^{1 / v}-1
$$

where $v$ is the number of ions in the salt $\left(18\right.$ for $\left.\mathrm{Ca}_{10}\left(\mathrm{PO}_{4}\right)_{6}(\mathrm{OH})_{2}\right)$, through ${ }^{[55]}$ :

$$
R=K \sigma^{n}
$$




\section{Introduction}

where $K$ is the rate constant (a function of the number of the active growth sites on the crystal surface) and $n$ is the apparent order of the crystallization reaction. There is a critical supersaturation ${ }^{[57]}$, above which the new phase would nucleate spontaneously by homogeneous nucleation. Nonetheless, at lower supersaturations stable nuclei of a new phase can form by heterogeneous nucleation upon specific surfaces. As the main driving force is an electrostatic interaction, the affinity increases with increasing surface charge.

The formation of amorphous precursors is frequently favoured: calcium ions in aqueous solutions are highly hydrated and therefore require an additional input of energy before they can form ordered crystal lattices. From neutral and basic electrolyte solutions, calcium phosphates usually precipitate in two steps: the first step is the formation of a precursor phase, most commonly amorphous calcium phosphate or octacalcium phosphate $\left(\mathrm{OCP},\left(\mathrm{Ca}_{8} \mathrm{H}_{2}\left(\mathrm{PO}_{4}\right)_{6}\right)\right.$, which may transform in a second step into calcium-deficient apatite or hydroxyapatite ${ }^{[57,58]}$. The calcium phosphate system is complicated as it involves a number of salts of variable stability ${ }^{[56]}$, but HAp is the only thermodynamically stable calcium phosphate that exists in aqueous solutions at $\mathrm{pH}$ greater than $4.2^{[59]}$.

It is a usual procedure to incubate the materials in $\mathrm{SBF}$ in a first treatment to form HAp nuclei (nucleation process), and afterwards soak them in modified SBFs with periodical renovation, with ion concentrations 1.5 or 2 times those of the SBF $(1.5 \times \mathrm{SBF}$ and $2 \times \mathrm{SBF}$, respectively). This increases the ionic activity product of the apatite while maintaining the $\mathrm{Ca} / \mathrm{P}$ molar ratio, and thereby make the apatite nuclei grow more rapidly (growth stage) ${ }^{[54,60,61]}$. Table 1.1 shows the ion concentrations and the ionic activity products of the apatite in $2 \times \mathrm{SBF}$.

\subsubsection{Mechanism of apatite formation on bioactive glasses}

In the past years, most of the studies with bioactive glasses and glass-ceramics were devoted to the understanding of the mechanism of apatite formation and the roles of the glass constituents, and to obtain simpler bioactive compositions based on the 
initial system $\mathrm{Na}_{2} \mathrm{O}-\mathrm{CaO}-\mathrm{SiO}_{2}-\mathrm{P}_{2} \mathrm{O}_{5}{ }^{[39,40,49-51,62-64]}$. Two important surface chemical changes are clearly involved in the apatite deposition mechanism on bioactive glasses:

i) preferential diffusion-controlled extraction of $\mathrm{Na}^{+}$and/or $\mathrm{Ca}^{2+}$ ions out of the glass by exchange with protons from the solution, and

ii) hydration and dissolution of the silica network itself, which is rather slow at physiological $\mathrm{pH}^{[65]}$ :

$$
\begin{gathered}
2\left(\equiv \mathrm{Si}^{-} \mathrm{O}^{-}\right) \mathrm{Ca}^{2+}+2 \mathrm{H}^{+} \rightarrow 2(\equiv \mathrm{Si}-\mathrm{OH})+\mathrm{Ca}^{2+} \\
\equiv \mathrm{Si}-\mathrm{O}-\mathrm{Si} \equiv+\mathrm{H}_{2} \mathrm{O} \rightarrow 2 \equiv \mathrm{Si}-\mathrm{OH}
\end{gathered}
$$

The mechanism of hydrolysis of $\equiv \mathrm{Si}-\mathrm{O}-\mathrm{Si} \equiv$ bonds involves the previous dissociation of a $\equiv \mathrm{Si}-\mathrm{OH}$ bond, followed by the nucleophilic attack of $\mathrm{H}_{2} \mathrm{O}$ to the $\mathrm{Si}^{4+}$ atom, which subsequently leads to the breakage of the $\equiv \mathrm{Si}(\mathrm{OH})-\mathrm{O}-\mathrm{Si} \equiv$ bond. Thus, the negatively charged surface species at high $\mathrm{pH}, \equiv \mathrm{Si}-\mathrm{O}^{-}$, control the rate of dissolution $[66]$.

The ions exchange $i$ ) results in a $\mathrm{pH}$ raise and an increase of the ionic activity product of the apatite in the SBF, which was already saturated with respect to HAp. Degradation (hydrolysis) of the silica network by the two processes (1.12 and 1.13) leads to the release of soluble $\mathrm{Si}(\mathrm{OH})_{4}$ into the medium and formation of $\equiv \mathrm{Si}$ $\mathrm{OH}$ groups at the glass-solution interface. These $\equiv \mathrm{Si}-\mathrm{OH}$ groups provide favourable sites for nucleation of the apatite, while the increasing number of $\mathrm{Ca}^{2+}$ ions accelerates the apatite precipitation and deposition on these nucleating sites.

The kinetics of formation of apatite on a glass is delayed with the ratio $\mathrm{SiO}_{2} /\left(\mathrm{Na}_{2} \mathrm{O}, \mathrm{CaO}\right)$, i.e, with increasing the silica content, because the mean number of nonbridging oxygens in the silica tetrahedron decreases ${ }^{[34]}$ (Figure 1.4). A silica-based glass has an open structure, which enables the accommodation of cations $\left(\mathrm{Na}^{+}\right.$or $\left.\mathrm{Ca}^{2+}\right)$. The presence of these cations results in disruption of the continuity of the network caused by the breaking of some of the $\mathrm{Si}-\mathrm{O}-\mathrm{Si}$ bonding. 


\section{Introduction}

This leads to a formation of nonbridging oxygen ions, which charge is balanced by a network modifier instead of sharing a corner with another tetrahedron. The bioactivity of the glass is based on the mean number of nonbridging oxygen ions in the silica tetrahedron. When exposed to body fluid, because of a rapid exchange of these cations for $\mathrm{H}^{+}$from the solution, a hydration of the gel structure occurs. That is why compositions of bioactive glasses with more than $60 \% \mathrm{SiO}_{2}$ cannot bond to bone and are bioinert, but increasing the specific surface area and microporosity by sol-gel process and sinterization $\left(600-700^{\circ} \mathrm{C}\right)^{[49,50,67]}$ instead of mixing and melting the oxides at higher temperatures $\left(1250-1400^{\circ} \mathrm{C}\right)$ can extend the bone bonding percentages of $\mathrm{SiO}_{2}$ in the glass up to $90 \%{ }^{[49]}$ or even to pure silica ${ }^{[68]}$.
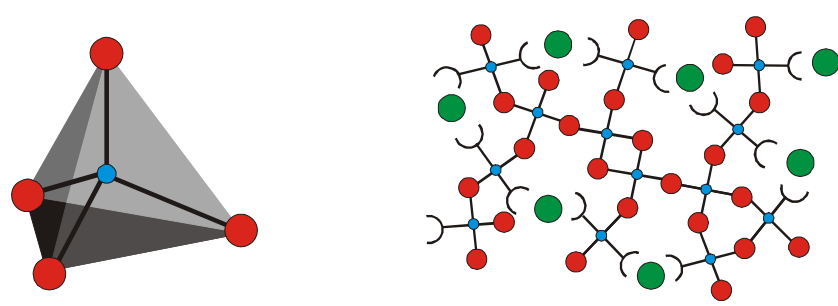

Figure 1.4 Left: Sketch of a basic building block of silica-based glasses: silicon (๑) ion is bonded to four oxygen ions (O) forming a tetrahedron. Right: Two-dimensional representation of a silicate glass: $\mathrm{Na}^{+}$or $\mathrm{Ca}^{2+}$ cations produce nonbridging oxygen ions.

At this point, how the formed silanols induce the apatite formation is not totally clear yet. It has been speculated that it does not occur directly but through the formation of a calcium silicate by electrostatic interactions ${ }^{\left[{ }^{[62,69]}\right.}$. The $\mathrm{pH}$ of the SBF (7.4) is much greater than the isoelectric point of the silica (approximately 2), and accordingly silica is much more soluble in alkaline solutions than in acidic ones ${ }^{[70]}$. The formed $\equiv \mathrm{Si}-\mathrm{OH}$ groups at the interface reveal negative charge by dissociation or local distribution of electron density. The glass thereby acquires a negative charge that enhances electrostatic interaction with the positively charged calcium ions in the fluid. This reaction results in the formation of an amorphous calcium silicate comprising a neutral or positive charge, as follows ${ }^{[53]}$ : 


$$
\begin{gathered}
2\left(\equiv \mathrm{Si}-\mathrm{O}^{-}\right)+\mathrm{Ca}^{2+} \rightarrow(\equiv \mathrm{Si}-\mathrm{O})_{2} \mathrm{Ca} \\
\left(\equiv \mathrm{Si}-\mathrm{O}^{-}\right)+\mathrm{Ca}^{2+} \rightarrow \equiv \mathrm{Si}-\mathrm{O}-\mathrm{Ca}^{+} \\
\mathrm{x}\left(\equiv \mathrm{Si}-\mathrm{O}^{\delta_{-}} \mathrm{H}\right)+\mathrm{Ca}^{2+} \rightarrow(\equiv \mathrm{Si}-\mathrm{OH})_{\mathrm{x}} \mathrm{Ca}^{2+}
\end{gathered}
$$

The surface thereby acquires a positive charge by accumulation of calcium ions, and interacts electrostatically with the negatively charged phosphate ions in the SBF, leading to the formation of an amorphous calcium phosphate. This amorphous calcium phosphate grows thereafter toward the outside of the substrate surface by incorporating the calcium and phosphate ions in the SBF. The formation of a precursor of hydroxyapatite and what follows is a well established phenomenon ${ }^{[51,58,62,63,69]}$ (Figure 1.5). Once the amorphous precursors of apatite or apatite nuclei are formed, they can grow spontaneously by consuming the calcium and phosphate ions from the surrounding body fluid, because the body fluid is supersaturated with respect to the apatite. During this process, the amorphous calcium phosphate incorporates $\mathrm{OH}^{-}$and $\mathrm{CO}_{3}{ }^{2-}, \mathrm{Na}^{+}, \mathrm{K}^{+}$and $\mathrm{Mg}^{2+}$ ions from the solution and finally crystallizes into HAp, which is the most stable calcium phosphate in aqueous media, rendering a HAp layer of polycrystalline agglomerates of carbonated hydroxyapatite on the substrate.

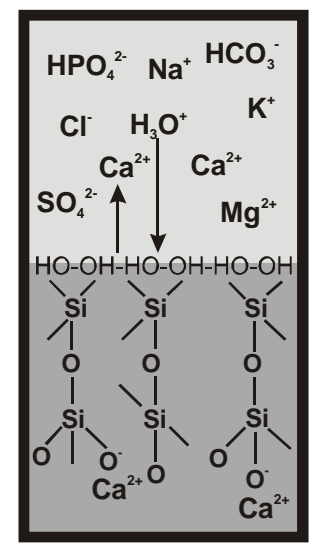

Formation of Si-OH groups

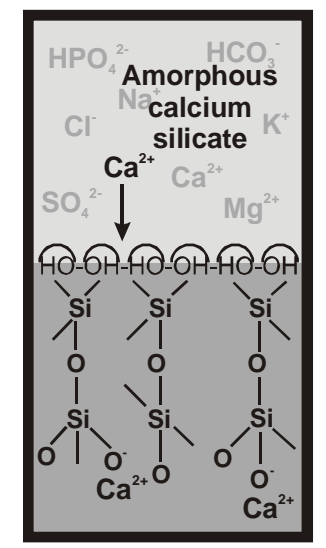

Formation of amorphous calcium silicate

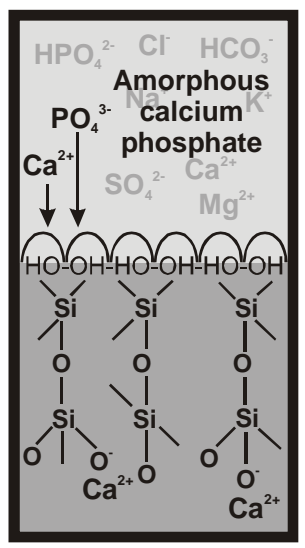

Formation of amorphous calcium phosphate

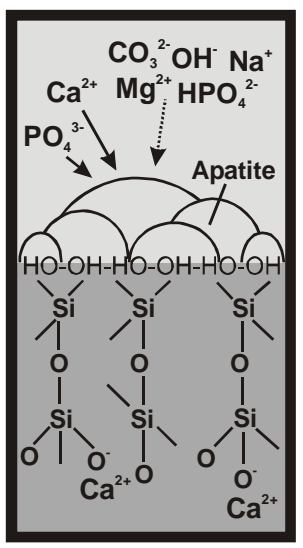

Formation of crystalline apatite

Figure 1.5 Mechanism of apatite nucleation on a $\mathrm{CaO}-\mathrm{SiO}_{2}$ glass (inspired in reference [48]). 


\section{Introduction}

The ability of a surface to precipitate calcium phosphate from SBF depends on its ability to decrease the activation barriers of the spontaneous precipitation ${ }^{[71,72]}$. This may occur either via homogeneous nucleation in solution, induced by modification of the solution critical saturation via calcium ion or silicic acid release, or via heterogeneous nucleation on specific surface sites. Actually, the calcium ions in bioactive glasses do not take part in the apatite nucleation itself, but its presence in the silica network facilitates the hydrolysis, and their release to the medium modifies the saturation of the SBF solution. A large amount of silanol groups on the substrate seems to be a prerequisite to apatite formation ${ }^{[73]}$. This suggests that biomineralization can be induced by the formation of specific surface functional groups acting as effective sites for heterogeneous nucleation of apatite, even with $\mathrm{Ca}$ and $\mathrm{P}$ absent from the composition. In fact, different functional groups able to develop negative charge at the blood plasma $\mathrm{pH}$, aside from Si-OH [69], have been found to be effective for calcium phosphate nucleation, e.g. phosphate, carboxyl, hydroxyl, amine and sulfonic groups [51-53,63,74-76]. The mechanism of apatite formation is believed to involve electrostatic interactions between these functional groups and the ions from the SBF.

\subsubsection{Biomimetic approaches to bioactive materials for hard tissue engineering: bioactive hybrids and bioactive surface functionalization}

The use of bioactive glasses as implant materials or in manufacturing medical devices is limited by their poor mechanical properties. Glasses can be cast to plates, rods, etc. or be used as filler materials in the form or particulates, but their brittleness makes difficult their use in load-bearing applications. One approach to enhance the mechanical properties of these materials is the preparation of organic/inorganic hybrids, in which the inorganic phase is incorporated into an organic polymeric matrix. This type of structural organizations aims to mimic the composition of mineralized tissues, where the inorganic phase HAp is dispersed in a collagen matrix, with which interacts at a molecular scale yielding a natural composite. Various hybrid systems have been explored, employing as inorganic 
phase bioactive glasses ${ }^{[72,77]}$, HAp ${ }^{[78-80]}$ or pure silica ${ }^{[72]}$, in the form of particles or fibres. Porous scaffolds of hybrid composites mimicking natural bone structures have been prepared and investigated to serve as a support, reinforce and guide new tissue in-growth and regeneration ${ }^{[81-88]}$. These bioactive hybrids join the easy processability and structural control of the polymers with the bioactive character of the glasses. In the last years, some studies have been devoted to the study of organic/inorganic nanocomposites, with the aim of combining the properties of both phases at the nanoscale level. Polymer/silica nanocomposites have been prepared by physically mixing silica nanoparticles with polymers ${ }^{[89,90]}$ or by copolymerization of the organic polymers with surface-functionalized silica nanoparticles ${ }^{[91,92]}$.

Besides, a wide variety of procedures have been proposed with the purpose of improving the bone-bonding ability of bioinert substrates or shortening the induction period required for apatite deposition from SBF. These procedures are based on:

i) the pre-calcification of the surfaces,

ii) the impregnation of the surfaces with nucleating agents, or

iii) the modification of the surfaces with functional groups effective for the apatite nucleation to confer them bioactivity.

Inspired in the previous studies performed on $\mathrm{CaO}-\mathrm{SiO}_{2}$-based glasses, Abe et al. ${ }^{[93]}$ developed a biomimetic process (procedure type $i$ ) to precipitate a HAp layer on bioinert organic polymers, ceramics and metallic materials. Apatite nucleation is carried out by immersing the samples in $\mathrm{SBF}$ in the presence of a plate of $\mathrm{CaO}-$ $\mathrm{SiO}_{2}$-based glass as a source of nucleating ions of apatite. Silicate ions dissolved from the glass are adsorbed on the substrate to induce apatite nucleation. Dissolution of calcium ions increases the ionic activity product of the apatite in the $\mathrm{SBF}$ and accelerates apatite nucleation. The silicate ions, e.g., $\mathrm{Si}(\mathrm{OH})_{4}, \mathrm{SiO}(\mathrm{OH})_{3}$ and $\mathrm{SiO}_{2}(\mathrm{OH})_{2}{ }^{2-}$, are assumed to attach with polar groups on the surface, and recondense, leaving silanol terminal groups ${ }^{[69]}$. Once nucleation occurs, i.e., the 


\section{Introduction}

surface is already pre-calcified, the glass is not needed and apatite nuclei grow spontaneously on the substrate to form an apatite layer by consuming calcium and phosphate ions from the SBF. Kim et al. ${ }^{[54]}$ and Tanahashi et al. ${ }^{[61]}$ performed similar experiments on polymeric substrates with different sources of nucleating agents. The latter observed that the adhesive strength of the apatite layer to the substrate varied largely with the kind of polymers. It increased with the surface roughness and with the presence of polar groups on the surface, forming a strong bond with the hydroxyl group or calcium ion of the apatite, whereas non-polar polymers bonded to the apatite only by weak van der Waals forces. The drawback of this method is that only the surface of the substrate facing the glass particles is able to form apatite.

Oliveira et al. ${ }^{[60,74]}$ proposed a methodology to generate apatite nucleating sites on the surface of starch-based biodegradable materials or other polymeric biomaterials (with relatively strong swelling ability) and scaffolds, based on the impregnation of the samples with a sodium silicate gel containing $\mathrm{NaOH}$ (procedure type ii). The hydrogen bonding complexes formed between $\mathrm{NaOH}$ and hydroxyl groups increase the surface hydrophilicity (higher amount of polar groups in the surface). The alkali attack contributes to the formation of silanol groups that act as apatite nucleation inductors. Besides, the adsorption of $\mathrm{Ca}^{2+}$ ions leads to the formation of additional nucleating sites by a chelation effect. Other authors achieved apatite formation on different polymers by soaking them previously in a titania ${ }^{[94]}$ or calcium silicate ${ }^{[95,96]}$ solutions.

Various surface modification techniques have been proposed aiming to make polymer surfaces able of inducing apatite nucleation when immersed in SBF. These methods (type iii) are based on the introduction of hydrophilic polar groups, such as phosphate, hydroxyl groups, $\mathrm{Si}-\mathrm{OH}$ or $\mathrm{Ti}-\mathrm{OH}$, and carboxyl and carboxylate groups, which have been found to be effective for apatite nucleation, onto more hydrophobic less bioactive substrates ${ }^{[53,73,76,97-100]}$. 
Taguchi et al. ${ }^{[101]}$ developed a simple method that combines the modification of the surfaces with functional groups effective for the apatite nucleation and a rapid precalcification. In a first step, polyethylene substrates were surface-grafted with hydrophilic poly(acrylic acid) or poly(acryl amide) to introduce carboxyl or amide groups, respectively. Afterwards, the pre-treated materials were alternatively soaked in $\mathrm{Ca}$ and $\mathrm{P}$ solutions (CaP treatment), in order to nucleate precursors of apatite in the previously formed nucleating sites. The CaP treatment consisted in dipping the samples consecutively in an aqueous $\mathrm{CaCl}_{2}$ solution (Ca solution) for a pre-determined period of time, in ultra-pure water, in aqueous $\mathrm{Na}_{2} \mathrm{HPO}_{4}$ solution ( $\mathrm{P}$ solution) for another period of time, dipping in ultra-pure water, and finally soaking them in acetone and drying. The rapid $\mathrm{Ca}$ adsorption was thought to be the key factor in the coating process during the CaP treatment. More recently, Oyane et al. ${ }^{[102]}$ proposed an analogous procedure. In a first step, a poly $(\varepsilon-$ caprolactone) substrate was treated with aqueous $\mathrm{NaOH}$ to introduce carboxylate groups onto the surface. Afterwards, the $\mathrm{NaOH}$-treated materials underwent an alternate soaking treatment in $\mathrm{CaCl}_{2}$ and $\mathrm{K}_{2} \mathrm{HPO}_{4} \cdot 3 \mathrm{H}_{2} \mathrm{O}$ solutions for three consecutive times. 


\subsection{Polymer/silica nanohybrids obtained by sol-gel process}

In the last years, many works have been carried out with regard to the structure, properties and possible applications of polymer/silica nanohybrids obtained by simultaneous polymerization of the organic phase during the in situ sol-gel polymerization of a silica precursor, with the aim of improving the mechanical properties. Polymers that have been hybridized with this purpose include poly $(\varepsilon-$ caprolactone) ${ }^{[103-106]}$, poly(2-hydroxyethyl methacrylate) ${ }^{[89-91,107-112]}$, poly $(2-$ hydroxyethyl acrylate) ${ }^{[113]}$, poly(methyl methacrylate) ${ }^{[92,114]}$, poly(butyl acrylate) ${ }^{[115]}$, poly(ethylene oxide) [116,117], poly(ethylene oxide-co-epichlorhydrin) [118], polyimide ${ }^{[119]}$, polyamide $6,6^{[120]}$, poly(vinyl acetate) ${ }^{[121]}$, or poly(vinyl alcohol) ${ }^{[122]}$.

Nonetheless, the idea of nanohybridizing biocompatible polymers with silica by this simultaneous in situ sol-gel polymerization, for the regeneration of mineralized tissues, is a very recent one. There are very few published works that address it. Rhee et al. ${ }^{[104,105]}$ polymerized poly(E-caprolactone) simultaneously via sol-gel with tetraethyl orthosilicate (TEOS) as silica precursor and calcium nitrate tetrahydrate to dope the nanohybrid with calcium ions. They characterized the HAp layer formed in a bioactivity test by scanning electron microscopy (SEM), Fourier transform infrared spectroscopy (FTIR), X-ray diffractometry (XRD) and inductively coupled plasma atomic emission spectroscopy (ICP-AES). Costa et al. [112] polymerized poly(2-hydroxyethyl methacrylate) by the same procedure with tetramethoxysilane (TMOS) as silica precursor and characterized the HAp layer formed in SBF by SEM and FTIR.

For carrying out a simultaneous in situ sol-gel polymerization, the organic component is commonly introduced as a precursor, i.e., a monomer or oligomer, and the mineral part with a silica precursor, such as tetraethoxysilane (TEOS, Si$\left.\left(\mathrm{O}-\mathrm{C}_{2} \mathrm{H}_{5}\right)_{4}\right)$. The organic polymerization is driven by the free radical polymerization of the monomer initiated by a thermal or photo-initiator, during the simultaneous sol-gel polymerization of the silicon alkoxide. This sol-gel process comprises 
hydrolysis of the silicon alkoxide to form silanols followed by autocondensation to polymerize into silica polymers, and the aggregation of partially condensed silica molecules to build up the network ${ }^{[70,123]}$ :

Hydrolysis:

$$
\equiv \mathrm{Si}-\mathrm{O}-\mathrm{C}_{2} \mathrm{H}_{5}+\mathrm{H}_{2} \mathrm{O} \rightarrow \text { 三Si-OH }+\mathrm{C}_{2} \mathrm{H}_{5} \mathrm{OH}
$$

Condensation:

$$
\begin{gathered}
\equiv \mathrm{Si}-\mathrm{OH}+\mathrm{HO}-\mathrm{Si} \equiv \rightarrow \equiv \mathrm{Si}-\mathrm{O}-\mathrm{Si} \equiv+\mathrm{H}_{2} \mathrm{O} \\
\text { (water-producing condensation) } \\
\equiv \mathrm{Si}-\mathrm{OH}+\mathrm{C}_{2} \mathrm{H}_{5}-\mathrm{O}-\mathrm{Si} \equiv \rightarrow \text { } \equiv \mathrm{Si}-\mathrm{O}-\mathrm{Si} \equiv+\mathrm{C}_{2} \mathrm{H}_{5} \mathrm{OH}
\end{gathered}
$$

(alcohol-producing condensation)

The chemical process can be summarized as:

$$
\mathrm{Si}-\left(\mathrm{O}-\mathrm{C}_{2} \mathrm{H}_{5}\right)_{4}+2 \mathrm{H}_{2} \mathrm{O} \rightarrow \mathrm{SiO}_{2}+4 \mathrm{C}_{2} \mathrm{H}_{5} \mathrm{OH}
$$

The hydrolysis and polycondensation reactions initiate at numerous sites within the solution. When sufficient interconnected Si-O-Si bonds occur in a region, they form solid colloidal nanoparticles (with diameters about $6 \mathrm{~nm}$ ) dispersed in the liquid, i.e., a sol (Figure 1.6). The $\mathrm{H}_{2} \mathrm{O}$ and alcohol expelled from the reactions, and the organic monomeric mixture act as a template leaving pores in the few-nanometer range (around $3 \mathrm{~nm})^{[124-127]}$. The size of the sol particles and the crosslinking (or density) within them depend on the $\mathrm{pH}$ and the $\mathrm{H}_{2} \mathrm{O}$ /TEOS ratio. With time, if the amount of TEOS is sufficient, the colloidal particles can link together or aggregate and ultimately give place to a porous three-dimensional continuous molecule network, whose characteristics will depend on the size of the particles and extent of crosslinking ${ }^{[91,124-129]}$. Siloxane groups form the internal part of the 


\section{Introduction}

inorganic polymer and are coated by silanol groups distributed on the surface. These silanol groups are responsible for the reactivity of the silica surface ${ }^{[130]}$. The organic monomer polymerizes leaving an organic network that fills up both kinds of pores left by the silica structure (Figure 1.6).
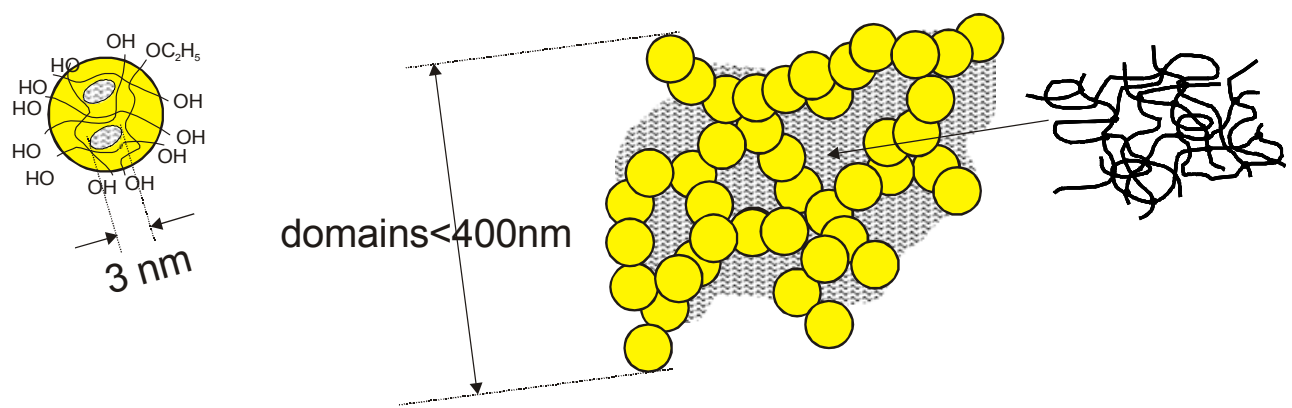

Figure 1.6 Porous structure of silica in the nanocomposites.

Although hydrolysis and condensations occur concurrently, the $\mathrm{pH}$, but also the amount of added water, the hydrophilicity of the polymeric monomer ${ }^{[131]}$, and the sometimes necessary addition of an alcoholic common solvent (ethanol, isopropanol) to homogenize the solution ${ }^{[132]}$, all affect the relative rate and extent of these reactions and thus the final structures and properties of the materials ${ }^{[125]}$. These reactions are generally activated by using base $\left(\mathrm{NaOH}, \mathrm{NH}_{4} \mathrm{OH}\right.$, etc.) or acid ( $\mathrm{HCl}, \mathrm{HF}$, etc.) catalysts. High $\mathrm{pH}$ conditions favor hydrolysis reactions and thus fast, larger, highly condensed silica polymers; on the contrary, in acid $\mathrm{pH}$ conditions, the rate of hydrolysis is slower and slightly condensed polymers are formed. Basic catalysts usually yield opaque composites with phase dimensions in the micrometer range. By contrast, if acid catalysts are used, transparent nanocomposites with characteristic morphology sizes below $100 \mathrm{~nm}$ are obtained ${ }^{[70]}$.

Both in acid and base conditions, hydrolysis seems to occur by nucleophilic attack of the water oxygen on the silicon atom ${ }^{[133]}$. Hydrolyses are facilitated by an increase of the concentration of $\mathrm{H}^{+}$in acidic media or the concentration of $\mathrm{OH}^{-}$in 
basic medium ${ }^{[125]}$, with the presence of water ${ }^{[125]}$ and with homogeneizing agents such as alcohol ${ }^{[133]}$, and accordingly the product of hydrolysis (alcohol and silanol) causes a further enhancement of the reaction rate ${ }^{[70,133,134]}$. However, concerning the silica condensation reaction, two different catalytic reactions govern this process above and below the silica isoelectric point $(\mathrm{pH} 2.2)^{[135]}$. These are the two extreme cases of relative hydrolysis/condensation reaction rates, depending on the solution $\mathrm{pH}$ and the concentrations of TEOS and water ${ }^{[70]}$ :

i) If the hydrolysis reaction proceeds faster than the condensation reaction, there are only hydroxyl groups and no alkoxy groups bonded to silicon when condensation commences. Under these conditions, condensations are believed to occur through a base catalyzed nucleophilic attack on silicon:

$$
\begin{array}{r}
(\mathrm{RO})_{3}-\mathrm{Si}-\mathrm{OH}+\mathrm{OH}^{-} \rightarrow(\mathrm{RO})_{3}-\mathrm{Si}_{-} \mathrm{O}^{-}+\mathrm{H}_{2} \mathrm{O} \text { (fast) } \\
(\mathrm{RO})_{3}{ }_{3} \mathrm{Si}-\mathrm{O}^{-}+(\mathrm{RO})_{3}-\mathrm{Si}-\mathrm{OH} \rightarrow(\mathrm{RO})_{3}-\mathrm{Si}-\mathrm{O}-\mathrm{Si}-(\mathrm{RO})_{3}+\mathrm{OH}^{-} \\
\quad \text { (rate determining) }
\end{array}
$$

where $\mathrm{R}$ is $\mathrm{H}$ or $\mathrm{Si}-\left(\mathrm{R}^{\prime} \mathrm{O}\right)_{3}$. The extent of the hydrolysis reaction increases with the acidity of the silanol proton on $(\mathrm{RO})_{3}-\mathrm{Si}-\mathrm{OH}$, so it will occur more probably in a polymer in which the $\mathrm{Si}$ is crosslinked via a bridging oxygen to another Si than in short chains, and more in middle than in end group silicons. The more extensive the crosslinking in $(\mathrm{RO})_{3}-\mathrm{Si}-\mathrm{OH}$, the more the acidity of the remaining silanol groups. The original weakly crosslinked polymers from the first hydrolysis tend to dissolve and reprecipitate on more highly condensed sites. As the most crosslinked $(\mathrm{RO})_{3}$-Si-OH species are the most likely to undergo reaction 1.19 and be available for reaction 1.20, the larger polymers grow at the expense of the smaller ones, resulting in large, highly branched and crosslinked polymers.

ii) If the rate of condensation of silanols is greater than their rate of production by hydrolysis, possible condensation sites are limited by the short extent of the hydrolysis. This occurs during acid catalyzed hydrolysis at low water 


\section{Introduction}

and acid concentrations. The acid catalyzed hydrolysis is not sensitive to the electronic effects of the other groups bonded to silicon but to steric effects, so monomers are more rapidly hydrolyzed that end groups of chains, which, in turn, are more rapidly hydrolyzed than the middle group of chains. The silanols on these weakly crosslinked units condense more rapidly than those on more highly crosslinked species are formed.

In this case, the condensation reaction is catalyzed by $\mathrm{H}^{+}$ions. An equilibrium condition is established between the excess $\mathrm{H}^{+}$ions and the silanol groups, resulting in temporarily positively charged species of the form $\equiv \mathrm{Si}-\mathrm{OH}_{2}{ }^{+}$that attract silanol groups, due to their positive charge. The least acidic silanols, i.e., those bound to the least condensed end groups are the most preferentially attacked by positively charged $\equiv \mathrm{Si}-\mathrm{OH}_{2}^{+}$species:

$$
\equiv \mathrm{Si}-\mathrm{OH}_{2}^{+}+\mathrm{Si}(\mathrm{OH})_{4} \rightarrow \equiv \mathrm{Si}-\mathrm{OH}^{+}-\mathrm{Si}(\mathrm{OH})_{3}+\mathrm{H}_{2} \mathrm{O}
$$

The additional proton is later removed either by a water or another $\operatorname{Si}(\mathrm{OH})_{4}$ molecule. Condensations occurring between ends of chains promote the formation of linear chains or weakly crosslinked or branched structures of relatively small size and low degree of internal condensation ${ }^{[107,135]}$.

The solubility of silica increases with the $\mathrm{pH}$. Over the low to medium $\mathrm{pH}$ range, where the solubility of silica is minimal, depolymerization is not likely to occur. The siloxane bonds cannot hydrolyze once they are formed. However, over the higher $\mathrm{pH}$ range, 7-9, the solubility is much greater, so the rate of condensation is no longer proportional to the $\mathrm{OH}^{-}$content ${ }^{[135]}$. The occurrence of reverse reactions depending on the processing conditions may result in a wide range of structures ranging from molecular networks to colloidal particles if depolymerization and rearrangement into particles occurs ${ }^{[125]}$. 


\subsection{Purpose of the study}

In the present work, a random acrylic copolymer will be employed to synthesize and characterize silica-based nanohybrids, as promising candidates for the synthetic matrix of scaffolds for guided dentin regeneration. Tetraethoxysilane, TEOS, will be used as silica precursor. Acrylates have been proposed in the literature for biomedical applications because of their good biocompatibility and water permeation characteristics ${ }^{[136-138]}$. A 70/30 wt\% hydrophobic/hydrophilic copolymer of poly(ethyl methacrylate-co-hydroxyethyl acrylate), P(EMA-co-HEA), has been chosen according to two requirements: good mechanical properties provided by the EMA component and hydrophilicity of the HEA needed for a good miscibility of the TEOS mixture ${ }^{[113]}$, for the transport of oxygen and nutrients and for cells metabolism. $\mathrm{P}$ (EMA-co-HEA) $/ \mathrm{SiO}_{2}$ nanocomposites with different silica contents in the range of 0-30 wt\% will be obtained. $\mathrm{P}(\mathrm{EMA})$ and $\mathrm{P}(\mathrm{HEA})$ homopolymers will be also synthesized to be used as controls. The incorporation of the silica network is expected to reinforce mechanically the organic matrix. At the same time, it will confer bioactivity to the nanohybrids through the silanol terminal groups available at the surface and those later formed by dissolution of the silica network.

Firstly, the nanocomposites will be synthesized as sheets of approximately $0.8 \mathrm{~mm}$ in thickness, and the different structures of $\mathrm{SiO}_{2}$ in the $\mathrm{P}(\mathrm{EMA}-\mathrm{co}-\mathrm{HEA})$ polymeric matrix will be inferred from infrared spectroscopy, energy dispersive spectroscopy, thermogravimetry, pyrolysis, transmission electron microscopy and swelling measurements. Secondly, the bulk samples will be characterized by means of density assessments and contact angle measurements, differential scanning calorimetry, dynamic-mechanical analyses and compression mechanical tests, and their properties will be related with the respective morphologies. Subsequently, the bioactivity (apatite forming ability) of the bulk samples will be evaluated in terms of the morphology and composition of the apatite layers deposited on their surfaces, and the apatite nucleation mechanism will be elucidated on the basis of the substrates' composition. The characterization of the apatite formed on the substrates will be carried out by means of scanning electron microscopy, energy 


\section{Introduction}

dispersive spectroscopy, infrared spectroscopy and X-ray diffraction. The possibility of increasing the number of nucleating sites to reduce the incubation times necessary for apatite coating will be considered by following the surface modification method proposed by Oyane ${ }^{[102]}$.

This is, up to our knowledge, the first time that the apatite nucleation mechanism is characterised in a family of organic-inorganic nanohybrids in correlation with their different nanostructures. Moreover, this work shows the role of the connectivity (percolation) of the silica phase in the nanocomposites in promoting or hindering this process and contributes to clarify issues that have remained up to now disputed, which are the role of the silanol groups and the need or not of doping the materials with $\mathrm{Ca}$ or $\mathrm{Na}$ atoms in order to promote the apatite nucleation.

In this context, new synthetic organic/inorganic nanocomposite scaffolds that mimic the tubular porous morphology of natural extracellular matrix of dentin, possess compatible mechanical properties and apatite nucleation ability, will be presented. The scaffolds will be synthesized with silica contents in the range of 0-20 wt\%, by a fiber-templating fabrication method ${ }^{[139,140]}$, leaving tubular aligned pores of about $8 \mu \mathrm{m}$ of diameter. The series of scaffolds will be characterized by means of scanning electron microscopy, pyrolysis, porosity determination and compression mechanical measurements. The compatibility of the silica-based hybrid scaffolds with mineralized tissues will be followed in vitro by soaking in SBF. The architecture of the proposed scaffolds pretends the invasion by new odontoblast prolongations in the pores when implanted in vivo (ongoing work). The bioactive character of the scaffolds aims to be a crucial parameter for the good integration of the scaffolds in the host dentin tissue and for providing stimuli for differentiation of the pulpal surrounding cells and fabrication of more natural dentin when implanted in vivo, thereby guiding dentin tissue regeneration. 


\section{Chapter 2}

\section{Materials and methods}

\subsection{Materials}

As stated previously, the nanocomposites have been synthesized firstly as bulk sheets in order to determine the properties of the nanocomposite matrix of the scaffolds; the nanohybrid scaffolds have been characterized subsequently. This section has been, thus, divided into these two terms.

\subsubsection{Bulk samples}

Firstly, sheets of poly(ethyl methacrylate), PEMA, and poly(hydroxyethyl acrylate), PHEA, homopolymers (Figure 2.1) were obtained. The organic monomers ethyl methacrylate, EMA (99\%, Aldrich) and hydroxyethyl acrylate, HEA (96\%, Aldrich), were mixed separately with a $0.5 \%$ monomer weight of ethylene glycol dimethacrylate, EGDMA (98\%, Aldrich), as crosslinking agent and a $2 \%$ monomer weight of benzoyl peroxide, BPO (97\%, Fluka), as thermal initiator (Figure 2.2). After $30 \mathrm{~min}$ of stirring, both solutions were injected in moulds consisting in two glass plates with a rubber wire in between, in order to obtain sheets of $0.8 \mathrm{~mm}$ thickness. Polymerization was carried out in an oven at $60^{\circ} \mathrm{C}$ for $21 \mathrm{~h}$ and post-polymerization at $90^{\circ} \mathrm{C}$ for $18 \mathrm{~h}$. 
<smiles>CCOC(=O)C(C)C</smiles>

poly(ethyl methacrylate), PEMA

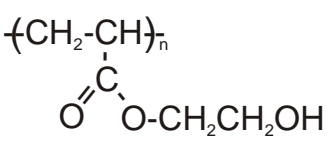

poly(hydroxyethyl acrylate), PHEA

Figure 2.1 Chemical structure of the homopolymers.<smiles>C=C(C)C(=O)OCCOC(=O)C(C)=O</smiles>

ethylene glycol dimethacrylate, EGDMA

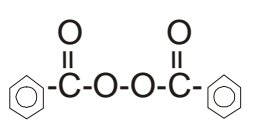

benzoyl peroxide, BPO

Figure 2.2 Chemical structure of the crosslinker and the thermal initiator.

The nanocomposites were obtained by undergoing a copolymerization of EMA and HEA, with $70 / 30$ wt\% of monomers ratio (Figure 2.1), during the simultaneous acid-catalyzed sol-gel polymerization of tetraethoxysilane (also called tetraethyl orthosilicate), TEOS (98\%, Aldrich), as silica precursor (Figure 2.3), following a similar procedure to that described, e.g., by Hajji et al. ${ }^{[91]}$.

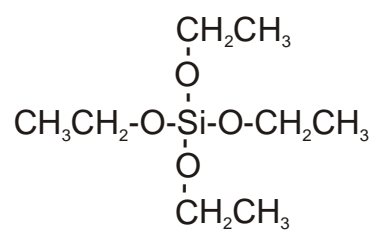

tetraethoxysilane, TEOS

Figure 2.3 Chemical structure of the silica precursor. 
Both organic monomers were mixed together with a 0.5 wt\% of EGDMA as crosslinking agent and a $2 \mathrm{wt} \%$ of $\mathrm{BPO}$ as thermal initiator, relative to monomer weight. Separately, a TEOS solution was prepared by mixing with distilled water and hydrogen chloride, $\mathrm{HCl}(37 \%$ wt $\mathrm{HCl} / \mathrm{wt}$ aqueous solution, Aldrich) in the molar ratio 1:2:0.0185, respectively. After $30 \mathrm{~min}$ of stirring, both solutions were mixed and stirred for 30 min more. The silica content was changed from 0 to 5,10 , 15, 20 and $30 \mathrm{wt} \%$ by controlling the $(\mathrm{EMA}+\mathrm{HEA}) /$ TEOS ratio and assuming that the sol-gel reactions were complete:

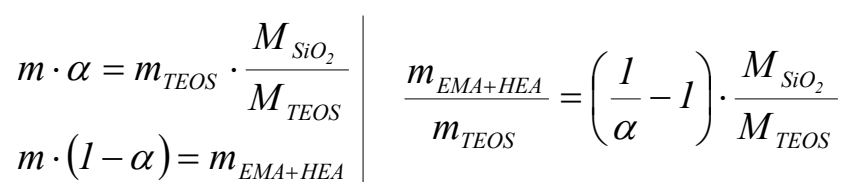

$m_{E M A+H E A}$ and $m_{T E O S}$ are the masses of EMA+HEA and TEOS, respectively; $m$ and $\alpha$ are the expected mass and the silica content (wt\%) of the resulting nanocomposite, respectively, and $M_{\text {SiO2 }}\left(60 \mathrm{gmol}^{-1}\right)$ and $M_{\text {TEOS }}\left(208 \mathrm{gmol}^{-1}\right)$ are the molar masses of silica and TEOS, respectively.

Polymerization was carried out in an oven at $60^{\circ} \mathrm{C}$ for $21 \mathrm{~h}$ and postpolymerization at $90^{\circ} \mathrm{C}$ for $18 \mathrm{~h}$, in moulds consisting in two glass plates with a rubber wire in between, in order to obtain sheets of $0.8 \mathrm{~mm}$ thickness. Subsequently, all the demoulded sheets were rinsed in a boiling distilled water/ethanol mixture for 24 hours to eliminate monomer residues and finally allowed to dry in a vacuum desiccator at $80^{\circ} \mathrm{C}$ until constant weight. Thus, sheets of both homopolymers and of poly(ethyl methacrylate-co-hydroxyethyl acrylate), $\mathrm{P}$ (EMA-co-HEA), 70/30 wt\% with varying proportions of silica, $\mathrm{SiO}_{2}$, up to 30 wt\% could be obtained (the terms silica and $\mathrm{SiO}_{2}$ are used indistinctly because they are not open to ambiguities throughout this work). Hereafter the hybrids will be referred to as $\mathrm{Hx}$, $\mathrm{x}$ being the percentage of silica. The composition of the different samples is given in Table 2.1 . 


\begin{tabular}{ll}
\hline Sample & Composition \\
\hline PEMA & P(EMA) \\
PHEA & P(HEA) \\
H00 & P(EMA-co-HEA) 70/30 wt $\%$ \\
H05 & P(EMA-co-HEA) $70 / 30 \mathrm{wt} \% / 5 \mathrm{wt} \% \mathrm{SiO}_{2}$ \\
H10 & P(EMA-co-HEA) $70 / 30 \mathrm{wt} \% / 10 \mathrm{wt} \% \mathrm{SiO}_{2}$ \\
H15 & P(EMA-co-HEA) 70/30 wt $\% / 15 \mathrm{wt} \% \mathrm{SiO}_{2}$ \\
H20 & P(EMA-co-HEA) 70/30 wt $\% / 20 \mathrm{wt} \% \mathrm{SiO}_{2}$ \\
H30 & P(EMA-co-HEA) 70/30 wt $\% / 30 \mathrm{wt} \% \mathrm{SiO}_{2}$ \\
\hline
\end{tabular}

Table 2.1 Sample compositions.

\subsubsection{Scaffolds of tubular parallel channels}

In order to obtain the scaffolds, glass tubes of $3 \mathrm{~mm}$ inner diameter were cut in 3.5 cm long pieces, stuffed with $10 \mu \mathrm{m}$ diameter polyacrylonitrile, PAN (Montefibre), aligned fibres and sealed on one side, to be used as templates. The monomeric mixtures were obtained as described previously. The hybrid solutions were vacuuminjected in these glass moulds, which were immediately capped and placed in an oven for polymerization at $60^{\circ} \mathrm{C}$ for $21 \mathrm{~h}$ followed by post-polymerization at $90^{\circ} \mathrm{C}$ for $18 \mathrm{~h}$.

Afterwards, the samples were demoulded and the PAN fibers were eliminated by dissolution in N,N-dimethylformamide (99.8\%, Aldrich). The resulting scaffolds were washed in a water/ethanol mixture to remove residuals and unreacted monomers and finally dried in a vacuum desiccator at $80^{\circ} \mathrm{C}$ until constant weight. Thus, nanohybrid scaffolds with aligned tubular pores of P(EMA-co-HEA) 70/30 wt\%, with varying proportions of silica up to $20 \mathrm{wt} \%$ were obtained. Scaffolds of PEMA and PHEA were prepared similarly. 


\subsection{In vitro test of bone bonding ability in SBF}

The ability of the different bulk materials and the H15 scaffolds to form HAp on their surfaces was tested in vitro. The bulk samples were swollen in a water/ethanol mixture and cut into disk pieces of $8 \mathrm{~mm}$ in diameter. Scaffolds of approximately $3 \mathrm{~mm}$ in length were also swollen in water/ethanol. A cotton thread was inserted through the different swollen samples to suspend them in vials and the samples were dried in a vacuum desiccator at $80^{\circ} \mathrm{C}$.

A simulated body fluid (SBF) solution was prepared with ion concentrations, $\mathrm{pH}$ and temperature nearly equal to those of the human blood plasma, as reported by Kokubo et al. ${ }^{[39,93]}$ (Table 1.1). In order to obtain the SBF, two solutions were prepared: solution 1 consisted in $1.599 \mathrm{~g}$ of $\mathrm{NaCl}$ (99\%, Scharlau), $0.045 \mathrm{~g}$ of $\mathrm{KCl}$ (99\%, Scharlau), $0.110 \mathrm{~g}$ of $\mathrm{CaCl}_{2} \cdot 6 \mathrm{H}_{2} \mathrm{O}$ (99\%, Fluka), and $0.061 \mathrm{~g}$ of $\mathrm{MgCl}_{2} \cdot 6 \mathrm{H}_{2} \mathrm{O}$ (Fluka) in deionized ultra-pure water (Scharlau) up to $100 \mathrm{ml}$; solution 2 was prepared by dissolving $0.032 \mathrm{~g}$ of $\mathrm{Na}_{2} \mathrm{SO}_{4} \cdot 10 \mathrm{H}_{2} \mathrm{O}$ (Fluka), $0.071 \mathrm{~g}$ of $\mathrm{NaHCO}_{3}$ (Fluka), and $0.046 \mathrm{~g}$ of $\mathrm{K}_{2} \mathrm{HPO}_{4} \cdot 3 \mathrm{H}_{2} \mathrm{O}$ (99\%, Aldrich) in water up to $100 \mathrm{ml}$. Both solutions were buffered at $\mathrm{pH} 7.4$, by adding the necessary amounts of aqueous $1 \mathrm{M}$ tris-hydroxymethyl aminomethane $\left(\mathrm{CH}_{2} \mathrm{OH}\right)_{3} \mathrm{CNH}_{2}$, Aldrich), and $1 \mathrm{M}$ hydrogen chloride ( $\mathrm{HCl}, 37 \%$, Aldrich). Then, both solutions were mixed to obtain SBF with the corresponding molar ion concentrations.

The disks were vertically suspended by the cotton thread in closed glass vials filled with SBF. The ratio of geometric surface area of sample (obviating the inner pores surface) to solution volume was $0.12 \mathrm{mlmm}^{-2}$, which is slightly higher than that proposed by Kokubo ${ }^{[38]}$. Samples were soaked in SBF for different times up to 35 days (14 days in the case of the H15 scaffold). The SBF solution was not renewed during the first 7 days. Afterwards, the ion concentrations were adjusted to twice those of SBF (2xSBF) and the solution was renewed each 2-3 days, in order to provide more favourable conditions for apatite deposition. The bulk samples were withdrawn from the SBF after 7, 14 and 35 days (H00, H15 and H30 samples also 


\section{Materials and methods}

after 1,3 and 5 days) and the scaffolds after 7 and 14 days, then gently rinsed with water, room conditioned and finally dried in a vacuum desiccator at $80^{\circ} \mathrm{C}$. 


\subsection{Surface treatments prior to the immersion in SBF}

Two series of bulk samples of the compositions H00, H15 and H30 were surfacemodified with the purpose of increasing the number of surface apatite nucleating sites and reducing the incubation times necessary for apatite coating. The samples were swollen in a water/ethanol mixture, cut into disk pieces of $8 \mathrm{~mm}$ diameter through which a cotton thread was inserted, and dried in a vacuum desiccator at $80^{\circ} \mathrm{C}$.

Firstly, the two series of samples were immersed in a $5 \mathrm{M} \mathrm{NaOH}$ aqueous solution at $50^{\circ} \mathrm{C}$ for $48 \mathrm{~h}$, following the procedure by Oyane et al. ${ }^{[102]}$. Once removed from the solution, the specimens were washed extensively with ultra-pure water, and dried at room temperature in air for a few minutes.

Half of the $\mathrm{NaOH}$-treated samples were soaked alternately in calcium ion and phosphate ion solutions by the following process (hereafter abbreviated as CaP treatment). The samples were dipped in $200 \mathrm{mM} \mathrm{CaCl} \cdot 6 \mathrm{H}_{2} 0$ (99\%, Fluka) aqueous solution for $10 \mathrm{~s}$, dipped in ultra-pure water for $1 \mathrm{~s}$, subsequently dipped in 200 $\mathrm{mM} \mathrm{K} \mathrm{HPO}_{4} \cdot 3 \mathrm{H}_{2} \mathrm{O}$ (99\%, Aldrich) aqueous solution for $10 \mathrm{~s}$ and dipped again in ultra-pure water for $1 \mathrm{~s}$. This alternate dipping in calcium and phosphate ion solutions was performed three consecutive times at room temperature.

The $\mathrm{NaOH}$-treated samples and those further subjected to the CaP treatment were immersed in SBF for 7, 14 and 35 days following the procedure described in the previous section. 


\subsection{Experimental techniques}

\subsubsection{Fourier Transform Infrared Spectroscopy (FTIR)}

The surface compositions of the bulk samples as-obtained and after different times of immersion in SBF were determined in a Thermo Nicolet Nexus FTIR (Thermo Fischer Scientific Inc., Waltham, MA, USA) spectrometer, in the attenuated total reflection mode (ATR). The spectra resulted from averages of 128 scans at $4 \mathrm{~cm}^{-1}$ resolution, between 650 and $4000 \mathrm{~cm}^{-1}$.

\subsubsection{Scanning Electron Microscopy (SEM)}

Scanning Electron Microscopy was employed to analyze the structure of the obtained scaffolds, the surface changes taking place on the bulk samples and the scaffolds during the bioactivity tests in SBF, and the surface modifications of the bulk samples in the $\mathrm{NaOH}$ and $\mathrm{CaP}$ treatments. A JSM-6300 microscope (JEOL Ltd., Tokyo, Japan) was used, with the samples previously sputter-coated with gold under vacuum, $15 \mathrm{kV}$ of acceleration voltage and $15 \mathrm{~mm}$ of distance working.

\subsubsection{Energy Dispersive X-ray Spectroscopy (EDS)}

The quantification of silica at the surfaces and in the interior of the bulk nanocomposites, and the compositional changes occurring during the bioactivity tests and the surface treatments were elucidated by microanalysis in an Energy Dispersive Spectrometer from Oxford Instruments, attached to the Scanning Electron Microscope. Samples were previously sputter-coated with carbon under vacuum. Spectra were taken at $10 \mathrm{kV}$ of acceleration voltage and $15 \mathrm{~mm}$ of distance working. Silicon was employed as optimization standard. 
The carbon, oxygen and silicon amounts could be obtained by EDS on the surfaces and in the bulk (by fracture) of the materials, but the EDS detector cannot detect the presence of hydrogen. The silica experimental contents, $\mathrm{SiO}_{2}{ }_{E D S}$, were quantified from the silicon average contents (neglecting the amount of hydrogen in the copolymer and in the silanol groups and the carbon coating of the samples for performing the EDS measurements) through the silica and silicon molar masses.

\subsubsection{Thermogravimetric Analysis (TGA)}

Thermogravimetric analyses were carried out to determine the decomposition profiles of the bulk samples and the decomposition residues. Measurements were done in a TA-SDT Q600 thermobalance (TA Instruments, New Castle, DE, USA) with approximately $7 \mathrm{mg}$ of sample accurately weighed in standard alumina crucibles. The temperature was raised from 25 to $1000^{\circ} \mathrm{C}$ at a rate of $10^{\circ} \mathrm{Cmin}^{-1}$ under a nitrogen flow of $50 \mathrm{mlmin}^{-1}$.

\subsubsection{Pyrolysis}

Small pieces of the bulk nanohybrids with $15 \mathrm{wt} \%$ of $\mathrm{SiO}_{2}$ and above, and of the H15 scaffolds, were pyrolized in a tubular oven (Gallur, Manises, Spain), programmed with a 3 hours ramp to $1000^{\circ} \mathrm{C}$ followed by a 4 hours isotherm, under oxygen atmosphere. The obtained residues were weighted and observed by SEM.

\subsubsection{Specific volume}

A Mettler AE 240 balance (Mettler-Toledo Inc., Columbus, OH, USA) with a sensitivity of $0.01 \mathrm{mg}$ with a Mettler ME 33360 accessory kit was used to measure the specific volume of the bulk samples through Archimedes' principle (the apparent weight of a solid immersed in a liquid decreases by an amount equal to 


\section{Materials and methods}

the weight of the liquid that it displaces). The dry samples were weighed in air and immersed in $n$-octane (95\%, Fluka, $\rho=0.702 \mathrm{gcm}^{-3}$ ) at room temperature. Each determination was repeated three times per sample.

The specific volume of each sample was determined as the volume of $n$-octane displaced, $V_{\text {displaced }}$, divided by the mass of the sample in air, $m_{\text {in air }}$ :

$$
v=\frac{V_{\text {displaced }}}{m_{\text {inair }}}=\frac{\left(m_{\text {in air }}-m_{\text {in n-octane }}\right) / \rho_{\text {-octane }}}{m_{\text {in air }}}
$$

where $m_{\text {in n-octane }}$ is the mass of the sample immersed in $n$-octane.

\subsubsection{Porosity}

The porosity of the scaffolds, $\pi$, was calculated through the specific volume of the respective bulk samples, and the weight and total volume of the scaffolds (calculated through the measurement of the height and diameter), in duplicate, according to the following equation:

$$
\pi=\frac{V_{\text {pores }}}{V}=\left(1-\frac{m_{\text {scaff }} \cdot v}{V}\right) \cdot 100
$$

where $V_{\text {pores }}$ is the pores volume, $V$ is the overall sample volume, $v$ is the specific volume of the corresponding bulk sample, and $m_{\text {scaff }}$ is the weight of the scaffold. 


\subsubsection{Transmission Electron Microscopy (TEM)}

The microstructure of the hybrids was observed with a FEI Tecnai Spirit Transmission Electron Microscope (FEI Company, Hillsboro, OR, USA) at $60 \mathrm{kV}$. Samples were previously cut in a cryogenic ultramicrotome, giving sections of 60 $\mathrm{nm}$ in thickness and prepared on a copper grid, pre-coated with a carbon support film. No staining was used to improve contrast.

\subsubsection{Solvent uptake}

The swelling of the bulk samples in water, in SBF and in a water/ethanol 50/50 vol\% mixture was quantified at equilibrium, by weighing fragments of dry samples and after equilibration to constant weight at room temperature, using the previously mentioned balance. A constant value of the weight was attained in around $48 \mathrm{~h}$. Measurements were repeated ten times in water and three times in SBF and water/ethanol, for each composition.

The equilibrium water content was obtained as the mass of water referred to the dry mass of the sample, $E W C$, and also referred to the HEA mass in the sample, $E W C^{\prime}$, defined as:

$$
E W C^{\prime}=\frac{m_{\text {water }}}{m_{H E A}}=\frac{m_{\text {water }} / m_{d r y}}{m_{H E A} / m_{d r y}}=\frac{E W C}{x_{H E A}}
$$

where $x_{H E A}$ is the mass ratio of HEA in the sample. The equilibrium water/ethanol contents, EWECs, were calculated as mass of solvent divided by the mass of dry sample, and also divided by the mass of copolymer in the dry hybrid, $E W E C^{\prime}$, considering in the last case that only the organic phase swells: 


$$
E W E C^{\prime}=\frac{m_{\text {water+ethanol }}}{m_{\text {copolymer }}}=\frac{m_{\text {water }+ \text { ethanol }} / m_{d r y}}{m_{\text {copolymer }} / m_{d r y}}=\frac{E W E C}{x_{\text {copolymer }}}
$$

In this equation, $x_{\text {copolymer }}$ is the mass ratio of copolymer in the sample.

\subsubsection{Contact angle measurements}

The surface wettability of the bulk samples was determined by measuring the contact angle on the surface of the samples of drops of three different liquids: water (extra pure, Scharlau), formamide (99.5\%, Aldrich) and diethylenglycol (99\%, Aldrich). A Dataphysics OCA instrument (DataPhysics Instruments GmbH, Filderstadt, Germany) was used for this purpose. A minimum of 10 drops of each liquid were analyzed for each composition.

The Young equation ${ }^{[141]}$ has been considered:

$$
\gamma_{s l}=\gamma_{s}-\gamma_{l} \cdot \cos \theta
$$

where $\gamma_{s l}, \gamma_{s}$, and $\gamma_{l}$ are the solid-liquid, solid-vapor and liquid-vapor interfacial tensions, respectively, and $\theta$ is the contact angle of the liquid on the surface. This equation has been combined with the relation by Owens and Wendt ${ }^{[142]}$, which supposes the surface tension as divided into two components, dispersive, $\gamma^{d}$, and polar, $\gamma^{p}$, and estimates:

$$
\gamma_{s l}=\gamma_{l}+\gamma_{s}-2 \cdot\left(\gamma_{l}^{d} \cdot \gamma_{s}^{d}\right)^{l / 2}-2 \cdot\left(\gamma_{l}^{p} \cdot \gamma_{s}^{p}\right)^{1 / 2}
$$


From equations 2.6 and 2.7, the following equation can be obtained:

$$
\frac{1+\cos \theta}{2} \cdot \frac{\gamma_{l}}{\left(\gamma_{l}^{d}\right)^{1 / 2}}=\left(\gamma_{s}^{d}\right)^{1 / 2}+\left(\frac{\gamma_{l}^{p}}{\gamma_{l}^{d}}\right)^{1 / 2} \cdot\left(\gamma_{s}^{p}\right)^{1 / 2}
$$

$\gamma_{l}$ and its components are tabulated for the different liquids (water, formamide and diethylenglycol) in Table 2.2 and $\theta$ are the measured contact angles of drops of these liquids on the surfaces of the dry samples. Representing $\frac{1+\cos \theta}{2} \cdot \frac{\gamma_{l}}{\left(\gamma_{l}^{d}\right)^{1 / 2}} v s$. $\left(\frac{\gamma_{l}^{p}}{\gamma_{l}^{d}}\right)^{1 / 2}$, the surface tensions of the samples surfaces, $\gamma_{s}$, and their dispersive, $\gamma_{s}^{d}$, and polar, $\gamma_{s}^{p}$, components, can be obtained from the y-ordinate and the slope, respectively.

\begin{tabular}{lccc}
\hline \multicolumn{1}{c}{ liquid } & $\gamma_{l}(\mathrm{mN} / \mathrm{m})$ & $\gamma_{l}^{d}(\mathrm{mN} / \mathrm{m})$ & $\gamma_{l}^{p}(\mathrm{mN} / \mathrm{m})$ \\
\hline water & 72.10 & 19.90 & 52.20 \\
diethylenglycol & 45.21 & 35.91 & 9.30 \\
formamide & 56.90 & 23.50 & 33.40 \\
\hline
\end{tabular}

Table 2.2 Liquids employed in the contact angle measurements, surface tensions $\gamma_{l}$, and their dispersive, $\gamma_{l}^{d}$, and polar, $\gamma^{p}$, components ${ }^{[143,144]}$.

\subsubsection{Differential Scanning Calorimetry (DSC)}

Differential Scanning Calorimetry measurements were undergone on a Mettler Toledo DSC 823e (Mettler-Toledo Inc., Columbus, OH, USA) to determine the thermal properties of the samples. Each test specimen consisted of approximately 8 $\mathrm{mg}$ of material accurately weighted in a standard aluminium pan and sealed. The pans were scanned from room temperature to $150^{\circ} \mathrm{C}$ at a heating rate of $10^{\circ} \mathrm{Cmin}^{-1}$, cooled to $-50^{\circ} \mathrm{C}$ at $40^{\circ} \mathrm{Cmin}^{-1}$ and reheated to $200^{\circ} \mathrm{C}$ at $10^{\circ} \mathrm{Cmin}^{-1}$, under nitrogen atmosphere. Calibration was made with indium and zinc standard. 


\subsubsection{Dynamic-Mechanical Spectroscopy (DMS)}

Dynamic-Mechanical Spectroscopy was performed in tension mode at $2^{\circ} \mathrm{Cmin}^{-1}$ in a Seiko DMS210 instrument (Seiko Instruments Inc., Chiba, Japan), from 25 to $200^{\circ} \mathrm{C}$ (from -60 to $200^{\circ} \mathrm{C}$ for the homopolymers and copolymer) at a frequency of 1 Hz. Specimens were rectangular shaped, approximately $25 \times 6.5 \times 0.8 \mathrm{~mm}^{3}$.

\subsubsection{Compression tests}

Mechanical compression tests were performed on the bulk samples and on the scaffolds (in the longitudinal direction), in the case of the scaffolds also after the immersion in SBF. The assays were carried out in a Seiko TMA/SS6000 device (Seiko Instruments Inc., Chiba, Japan), from 0.05 to $150 \mathrm{~g}$ at $10 \mathrm{gmin}^{-1}$, at room temperature. Bulk samples were disk shaped, approximately $3 \mathrm{~mm}$ in diameter. Scaffolds were cylindrical, approximately $3 \mathrm{~mm}$ in diameter and height. Each composition set consisted in four replicates. The compressive elastic moduli, $E_{b u l k}$ and $E_{\text {scff, }}$, were obtained from the initial slope of the stress-strain curves, rejecting the initial convex zone due to lack of parallelism of the surfaces, in order to assure that the load was homogeneously distributed on the surfaces.

\subsubsection{X-Ray Diffraction (XRD)}

Thin-film X-Ray diffraction spectra of the surfaces of the bulk samples after immersion in SBF were acquired in a Philips PW 1820 diffractometer (Koninklijke Philips Electronics N.V., Eindhoven, The Netherlands) with $\mathrm{Cu}$ K $\alpha$ radiation of $1200 \mathrm{~W}(40 \mathrm{kV}, 30 \mathrm{~mA})$, a scanning step of $1 \mathrm{~s}$ per step and an increment of $0.01^{\circ}$ over a $2 \theta$ range between 10 and $40^{\circ}$. 


\section{Chapter 3}

\section{Results}

\subsection{Structure of $\mathrm{SiO}_{2}$ in the $\mathrm{P}(\mathrm{EMA}-\mathrm{co}-\mathrm{HEA})$ matrix}

\subsubsection{Fourier Transform Infrared Analysis}

Figure 3.1 displays the FTIR spectra of the homopolymers and the copolymer in the dry state (black lines). The spectrum of PHEA shows a broad band between 3100 and $3700 \mathrm{~cm}^{-1}$, characteristic of the hydroxyl groups. This band does not appear in the copolymer spectrum. The $\mathrm{CH}_{\mathrm{x}}$ asymmetric and symmetric stretching peaks appear at 2962 and $2888 \mathrm{~cm}^{-1}$, respectively, but are less pronounced in the PEMA and H00 spectra. The well defined strong peak at $1700 \mathrm{~cm}^{-1}$ appearing in the three materials corresponds to the $\mathrm{C}=\mathrm{O}$ bonds of the carboxyl groups. Between 1500 and $650 \mathrm{~cm}^{-1}$ the three spectra are quite complex. 


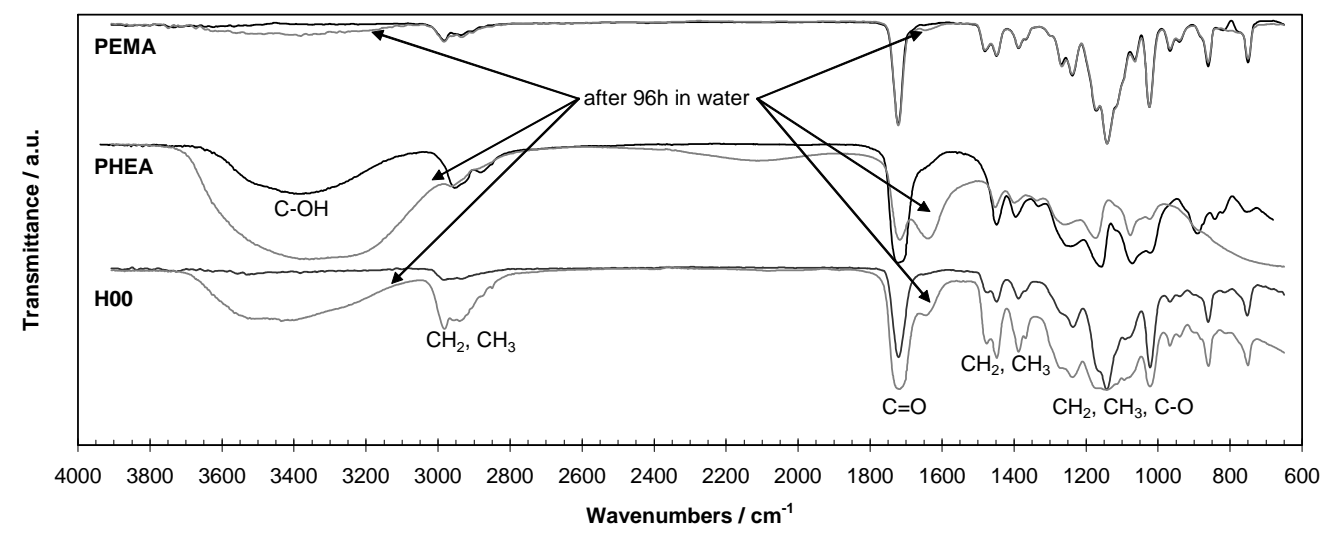

Figure 3.1 FTIR spectra (black lines) of dry PEMA, PHEA and H00, and (gray lines) after $96 \mathrm{~h}$ of immersion in water, in the $650-4000 \mathrm{~cm}^{-1}$ region.

Samples of the three compositions were immersed in water for 96 hours, and gently surface dried with desiccant paper. Then, the FTIR spectra were obtained, which have also been included in Figure 3.1 (gray lines). The broad band between 3700 and $3100 \mathrm{~cm}^{-1}$, as well as the shoulder at $1650 \mathrm{~cm}^{-1}$ next to the carbonyl peak, characteristic of water, appeared in all cases.

Figure 3.2 shows the spectra of the hybrids. The broad band assigned to the hydroxyl groups of the copolymer or silanols does not appear in the spectra of the hybrids. The $\mathrm{C}=\mathrm{O}$ stretching peak of the copolymer that appears at $1700 \mathrm{~cm}^{-1}$ tends to decrease with increasing silica contents. 


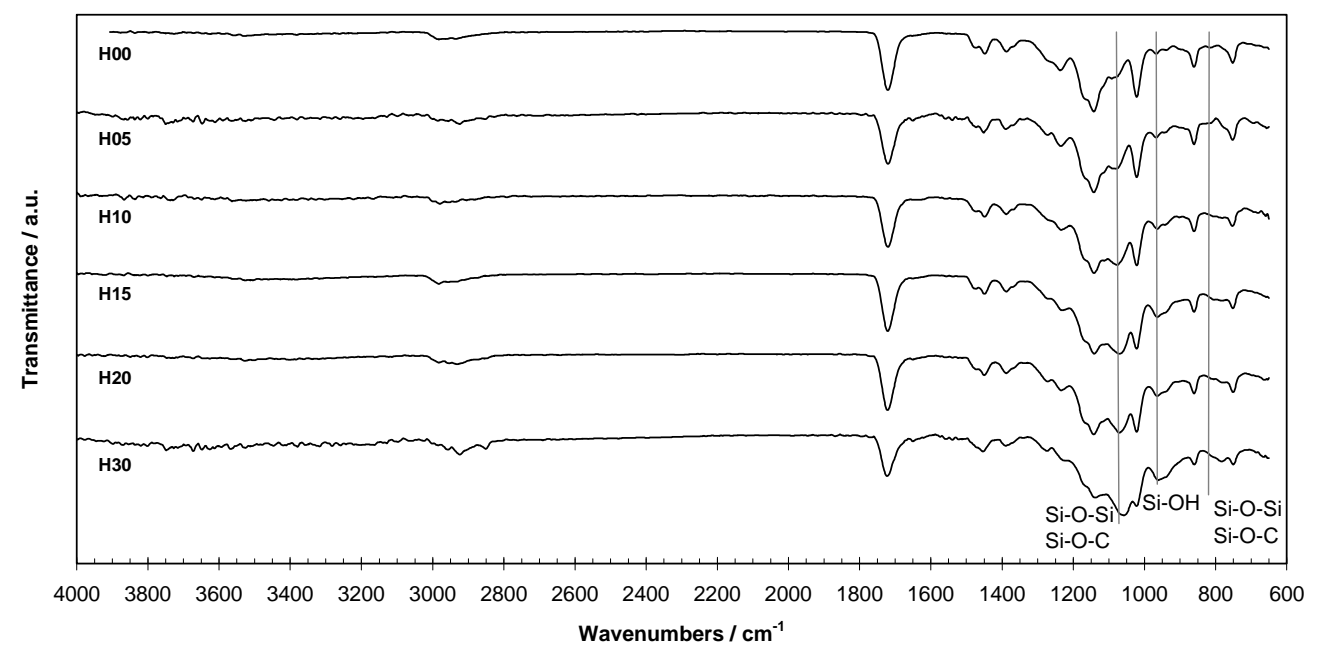

Figure 3.2 FTIR spectra of the nanocomposites in the $650-4000 \mathrm{~cm}^{-1}$ region.

At low wavenumbers, the complex spectrum of the copolymer obscures the silica fingerprint region, so it has been substracted from the spectra of the different nanohybrids. The resulting spectra after this substraction have been depicted in the 1400-600 $\mathrm{cm}^{-1}$ range in Figure 3.3.

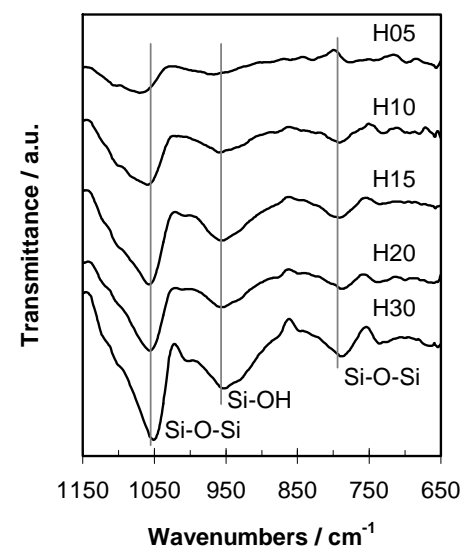

Figure 3.3 Substraction of the FTIR spectra of the hybrid nanocomposites and the spectrum of the copolymer. 


\section{Results}

The peaks appearing at $1060-1100$ and $800 \mathrm{~cm}^{-1}$ are attributed to the Si-O-Si asymmetric and symmetric stretching vibration, respectively, and the peak at 950 $\mathrm{cm}^{-1}$ is characteristic of the $\mathrm{Si}-\mathrm{OH}$ stretching vibration of the silica phase $[90,91,104,108,109,111,122,143]$. Their intensities increase proportionally to the silica content. Hybrid Si-O-C bonds from heterocondensation reactions at organic-inorganic interfaces could also be present (1120-1080 and $\left.836 \mathrm{~cm}^{-1}\right)$, as suggested in the literature ${ }^{[11,143,144]}$, but it cannot be confirmed from FTIR assays since they overlap the absorption interval of the Si-O-Si bonds.

\subsubsection{Energy Dispersive X-ray Spectroscopy}

The silica experimental contents, $\mathrm{SiO}_{2}{ }_{E D S}$, quantified from the silicon average contents, are represented in Figure 3.4. The surfaces and bulk silica percentages are very similar and correlate quite well with the nominal silica contents of the hybrids. The larger standard deviations of the silica contents obtained in the bulk are due to the limitations of this technique when working with fractured samples of variable height and with irregular topography instead of completely flat ones.

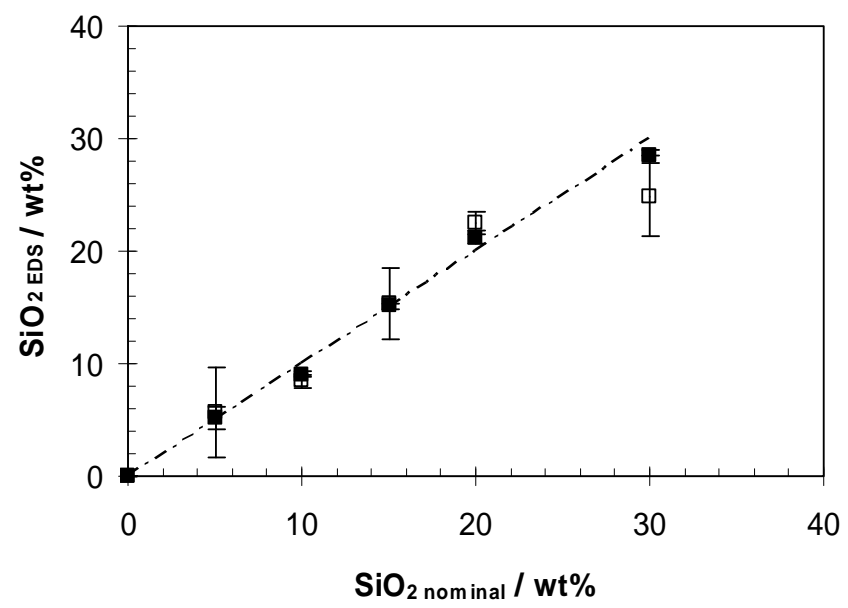

Figure 3.4 Average $\mathrm{SiO}_{2}$ contents obtained by EDS, $\mathrm{SiO}_{2}{ }_{E D S}$ : (ם) at the surface and $(\square)$ in the bulk, and (---) $\mathrm{SiO}_{2}$ nominal contents. 


\subsubsection{Thermogravimetric Analysis}

The residual mass, $w$, of both homopolymers and the copolymer due to thermal degradation, as well as the derivative curves, $d w / d T$, are shown in Figure 3.5.

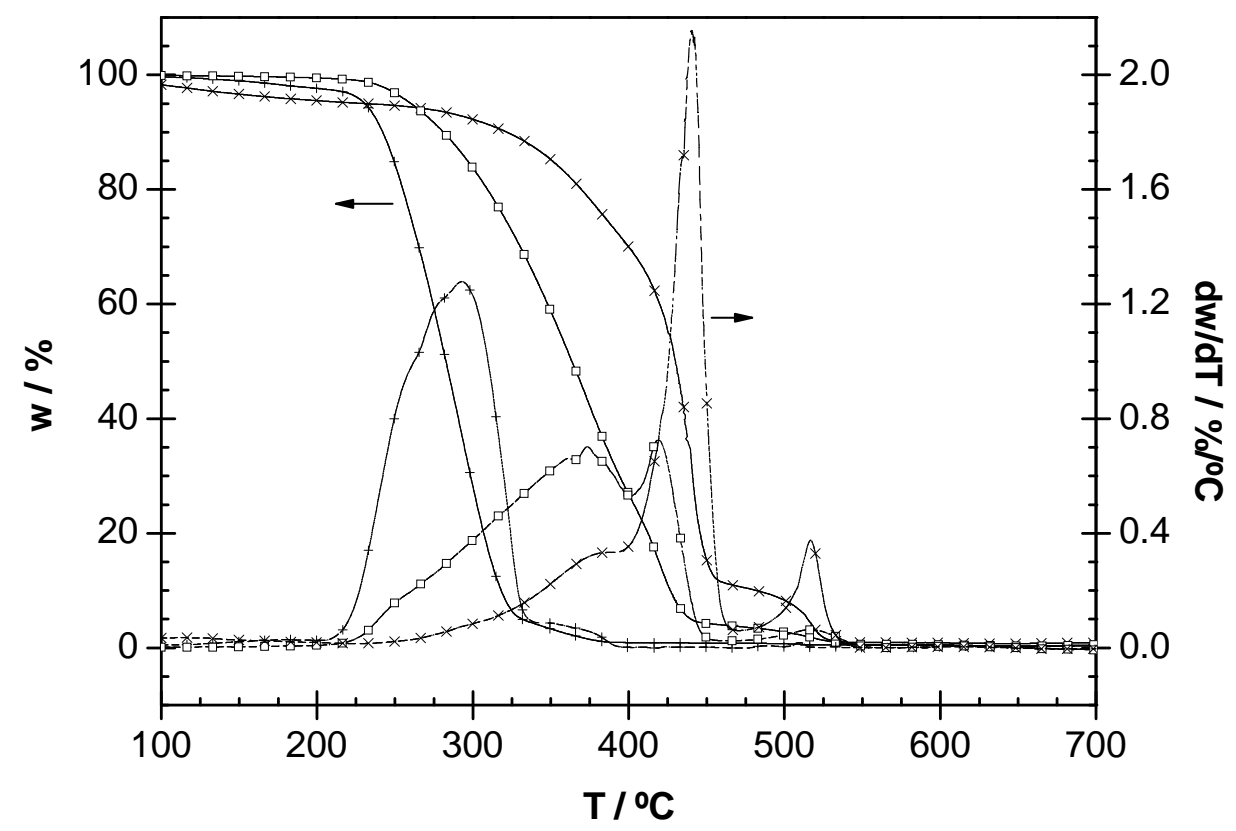

Figure 3.5 (-) Residual mass, $w$, as a function of temperature and (--) derivative curves, $d w / d T$, for: (+) PEMA, ( $\times$ ) PHEA and ( $\square)$ H00.

Decomposition of both PEMA and PHEA polymers seem to take place in two and three main stages, respectively, according to the derivative curves. PEMA decomposes between 210 and $395^{\circ} \mathrm{C}$, whereas PHEA decomposes at higher temperatures and more gradually, in the 300 to $550^{\circ} \mathrm{C}$ interval. The curves of the copolymer lie in the $220-550^{\circ} \mathrm{C}$ temperature interval, between those corresponding to both polymers, exhibiting three different main degradation steps. At $550^{\circ} \mathrm{C}$, all of them have totally decomposed without leaving residues. 


\section{Results}

The thermogravimetric plots of the silica nanocomposites are displayed in Figure 3.6. The weight loss seems to occur initially in three stages. The TGA curves shift to lower temperatures and the overall weight loss decreases when increasing the silica content. The first degradation step becomes more pronounced and the second gets smoother, as the derivative curves evidence. At the same time, the last weight loss step tends to vanish. The thermogravimetric curves of H15, H20 and H30 samples are almost identical, except for the final residues.
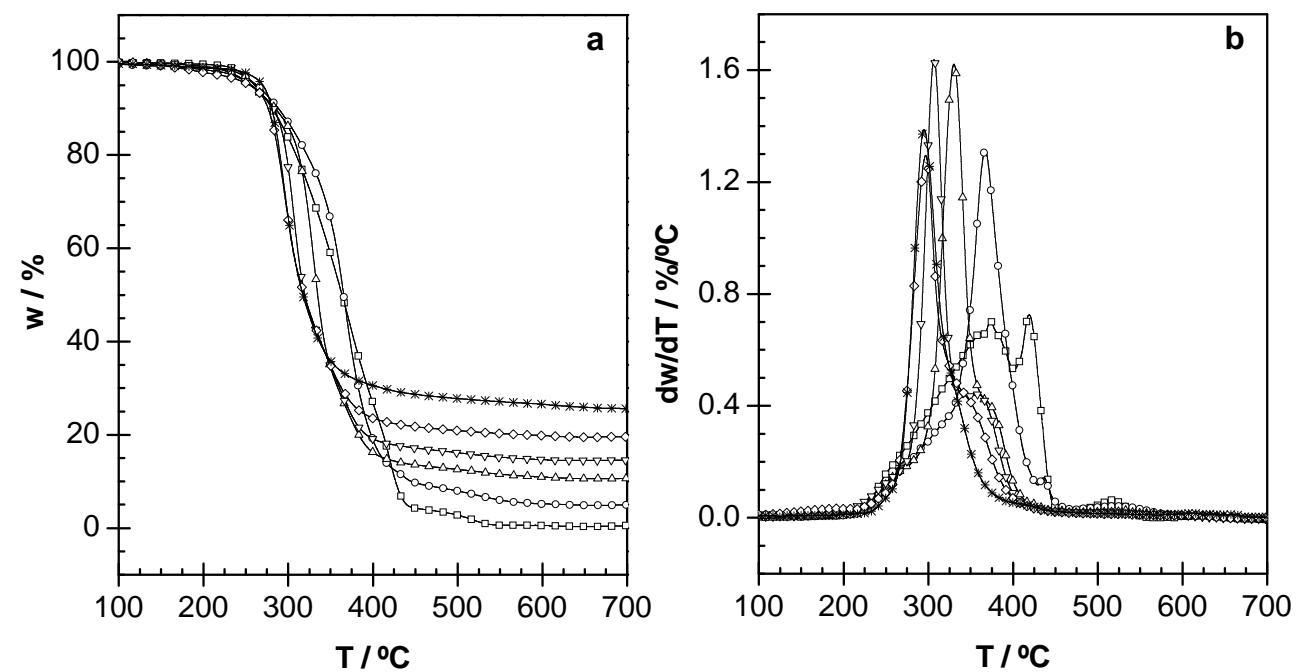

Figure 3.6 (a) Residual mass, $w$, as a function of temperature and (b) derivative curves, $d w / d T$, of: $(\square) \mathrm{H} 00,(\bigcirc) \mathrm{H} 05,(\triangle) \mathrm{H} 10,(\nabla) \mathrm{H} 15,(\diamond) \mathrm{H} 20$ and (*) H30.

The experimental percentages of residues, $w_{\gamma 00^{\circ} \mathrm{C}}$, have been determined at $700^{\circ} \mathrm{C}$ for the different samples and are represented in Figure 3.7. They agree well with the nominal inorganic contents in all cases. For H05 and H10, the residues after the measurements consisted in silica dust. However, for the hybrids with $15 \mathrm{wt} \%$ of $\mathrm{SiO}_{2}$ and above, residues could be removed easily from the pans as one piece. 


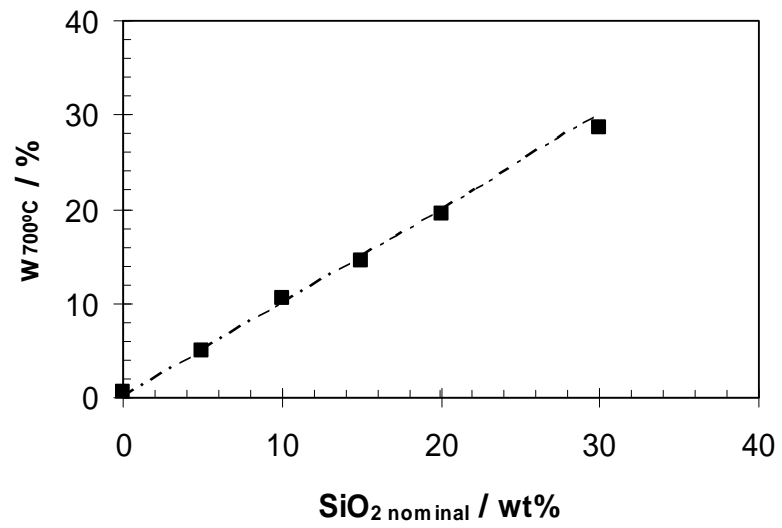

Figure 3.7 (घ) TGA residues at $700^{\circ} \mathrm{C}, w_{700^{\circ} \mathrm{C}}$, and (---) $\mathrm{SiO}_{2}$ nominal contents.

\subsubsection{Pyrolysis}

Figure 3.8 shows the SEM images of the pyrolysed residues of H15 and H30 fragments. The residues maintain the original shape but shrunk, displaying a smooth surface with occasional cracks. 
3. Results
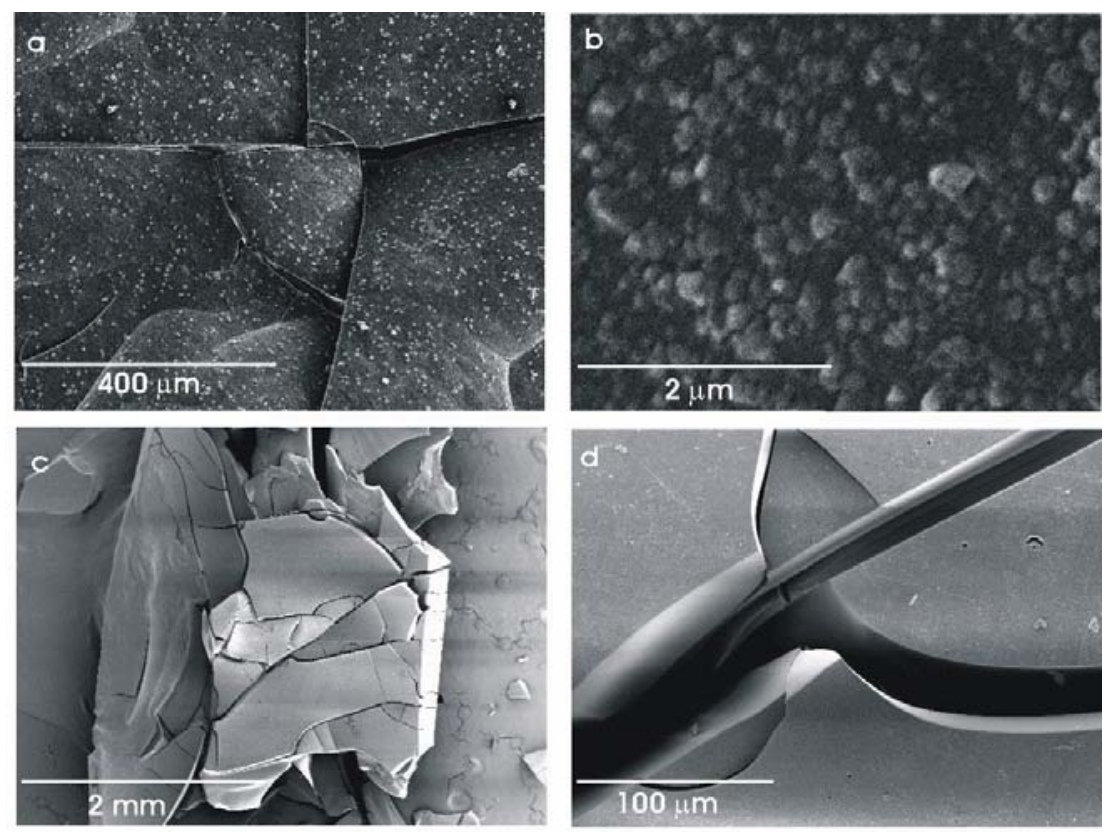

Figure 3.8 SEM images of pyrolysis residues from: (a, b) H15 and (c, d) H30.

\subsubsection{Transmission Electron Microscopy}

TEM images have been displayed in Figure 3.9 to give morphological evidence of the dispersion of silica. The silica phase (dark areas) is uniformly distributed in the nanoscale in all hybrids. Nanocomposites with low percentages of silica display a particle-matrix morphology (small non-interconnected particles dispersed in an organic matrix), which increases in density with the silica content. Gradually, these aggregates develop to produce co-continuous interpenetrated structures where individual silica aggregates are no longer seen. In the H30 sample, the discrete inorganic domains are no longer detectable. 

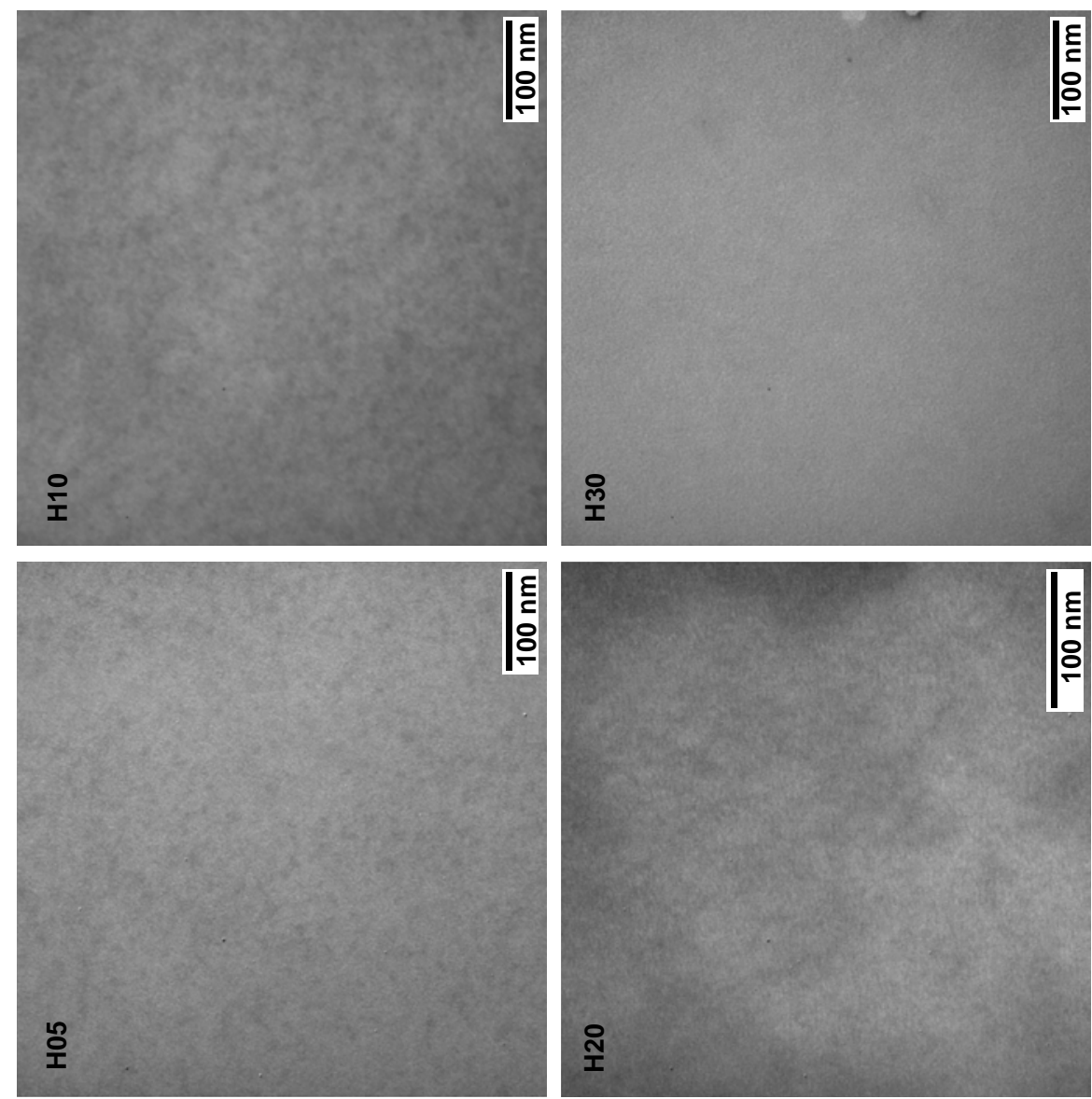

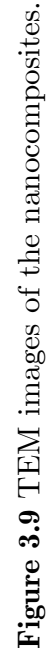
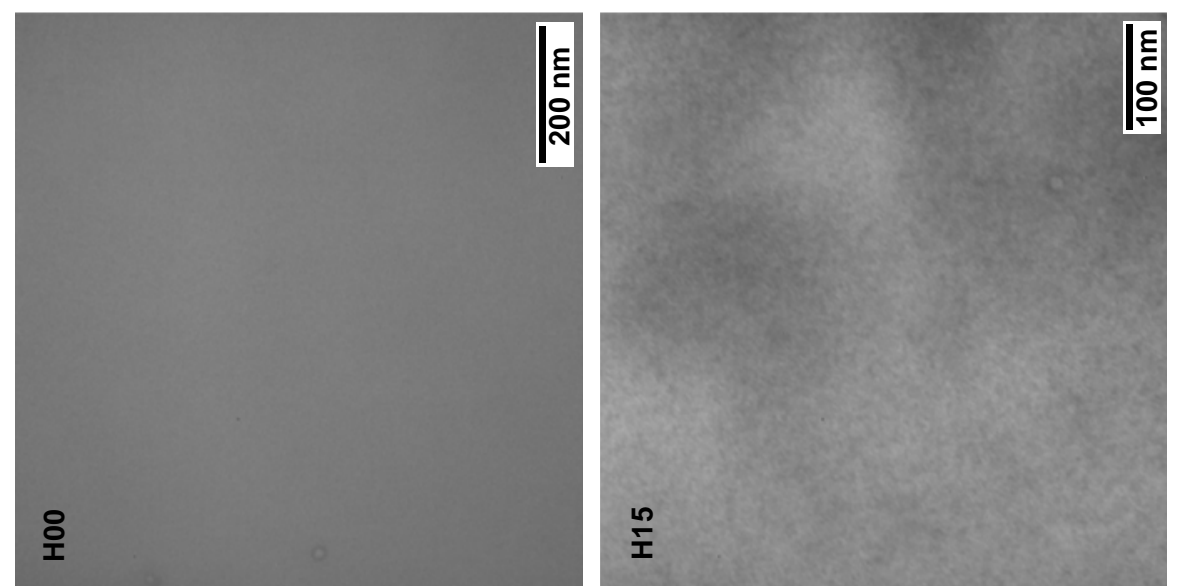


\subsubsection{Solvent uptake}

Figure 3.10 (a) displays the equilibrium water content of the nanocomposites referred to the dry mass of the sample, $E W C$, and also referred to the HEA mass in the sample, $E W C$ '. The error bars representing the standard deviation are also included. The EWCS for PEMA and PHEA are 1.18 and 202.52\%, respectively. The $E W C$ of the copolymer, $8.34 \%$, slightly decreases with the silica content up to $6.74 \%$ for $\mathrm{H} 20$, and abnormally increases for $\mathrm{H} 30$, which was very rigid as dry. The $E W C^{\prime}$ values do not vary significantly with the amount of silica. The theoretical equilibrium water contents, $E W C_{\text {theor }}$, have been calculated as a linear combination of the specific swelling capacities of both pure homopolymers, and are also represented.
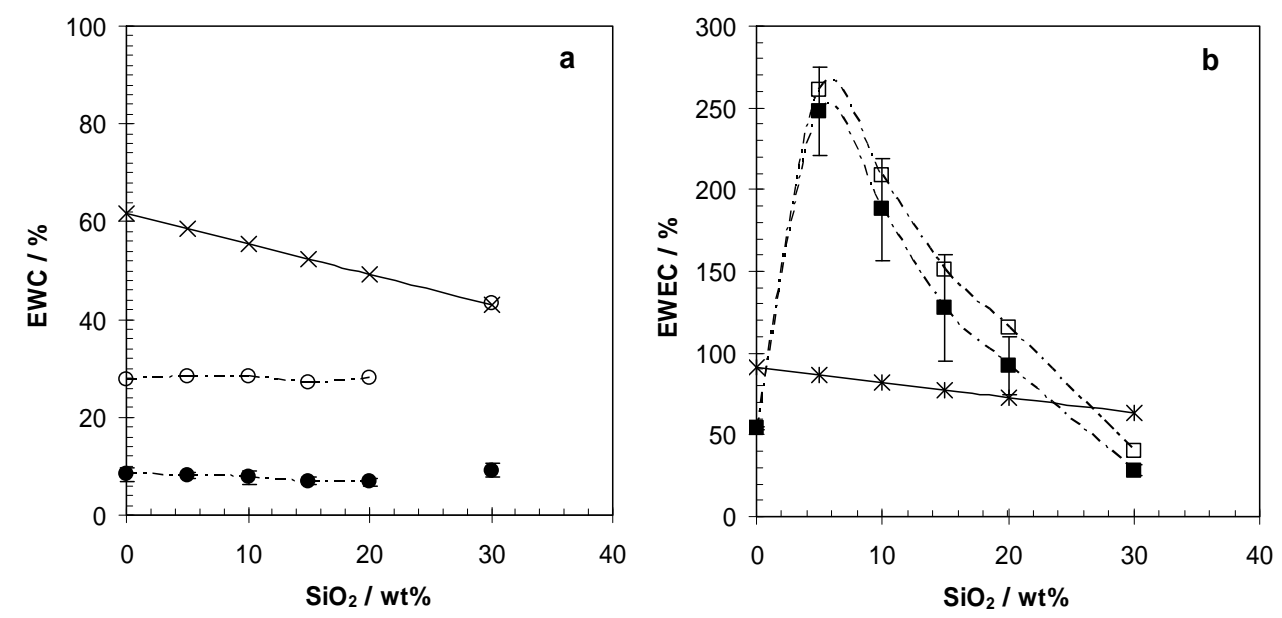

Figure 3.10 (a) Equilibrium water contents as a function of the silica contents: $(\bigcirc)$ referred to the dry mass of sample, $E W C$, $(\bigcirc)$ referred to the HEA mass in the sample, $E W C^{\prime},(\times)$ predicted from the EWC values of PEMA and PHEA, $E W C_{\text {theor }}$; (b) equilibrium water/ethanol contents as a function of the silica contents: $(\mathbf{\square})$ referred to the dry mass of sample, $E W E C,(\square)$ referred to the copolymer mass in the sample, $E W E C$ ', (*) predicted from the EWEC values of PEMA and PHEA, $E W E C_{\text {theor }}$. 
H00, H15 and H30 nanohybrids were swollen in SBF for $48 \mathrm{~h}$ (in order to avoid apatite deposition) and the equilibrium contents were $5.60 \%$ for $\mathrm{H} 00,7.02 \%$ for H15 and abnormally high $12.01 \%$ for H30.

The copolymer and the hybrids are quite rigid and do not absorb water in large quantities. On the contrary, ethanol swells very much the organic phase even causing the cracking of the nanocomposites with high silica contents. It was thus decided to swell the nanocomposites in a water/ethanol 50/50 vol\% mixture, with the aim of investigating the influence of silica on the copolymer matrix swelling capacity. Figure 3.10 (b) shows the equilibrium water/ethanol contents for the hybrids referred to the mass of sample, EWECs, and also to the mass of copolymer in the hybrid, $E W E C$ ', considering in the last case that only the organic phase swells. The theoretical water/ethanol equilibrium contents calculated as a linear combination of the specific swelling capacities of both pure homopolymers have also been represented, $E W E C_{\text {theor }}$, to compare them with the experimental $E W E C$ s. The $E W E C$ s for PEMA and PHEA are 33.27 and $225.64 \%$, respectively, and for the copolymer it is $54.00 \%$. The EWEC increases steeply for low silica contents, reaching a maximum somewhere around $5 \mathrm{wt} \%$ of silica, which is even higher than the PHEA EWEC, and decreases progressively afterwards until a value for H30 somewhat lower than that of PEMA. The $E W E C$ ' curve follows a similar tendency. 


\subsection{Characterization of $\mathrm{P}(\mathrm{EMA}-\mathrm{co}-\mathrm{HEA}) / \mathrm{SiO}_{2}$ nanocomposites}

All the obtained materials were optically transparent, and increasingly rigid with the silica content.

\subsubsection{Dynamic-Mechanical Spectroscopy}

Figure 3.11 shows the dynamic-mechanical spectra obtained for both homopolymers and the copolymer, in the temperature range from -60 to $200^{\circ} \mathrm{C}$, in terms of the storage modulus, $E^{\prime}$, and loss tangent, $\tan \delta$.

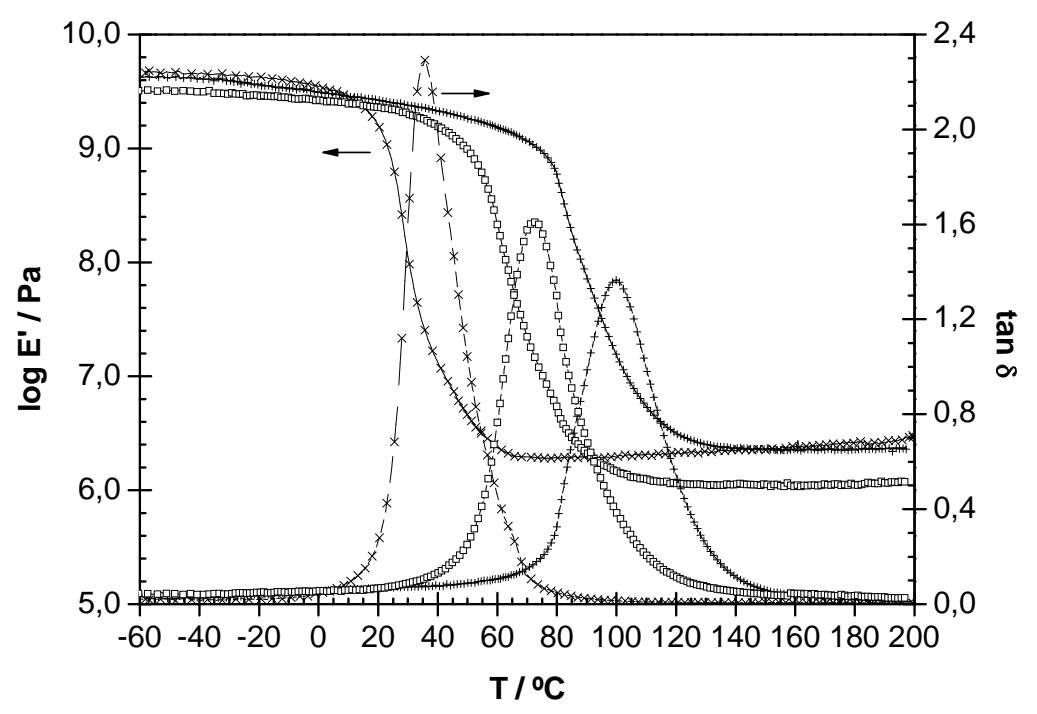

Figure 3.11 Temperature dependence of (-) the storage modulus, E', and (--) loss tangent, tan $\delta$, of: (+) PEMA, ( $\times$ ) PHEA and ( $\square)$ H00. 
The PHEA homopolymer presents the single peak in $\tan \delta$, with the maximum at $35.6^{\circ} \mathrm{C}$, characterizing its main relaxation process associated to the glass transition, whereas PEMA presents it at $101.4^{\circ} \mathrm{C}$. No secondary relaxations are observed at lower temperatures $\left(-60^{\circ} \mathrm{C}\right)$. The curves corresponding to the copolymer lie between the ones corresponding to both homopolymers. The main relaxation of the copolymer appears as a sharp single drop of the storage modulus, from 50 to $100^{\circ} \mathrm{C}$, with the corresponding maximum of the loss tangent at $67.2^{\circ} \mathrm{C}$.

The curves corresponding to the nanocomposites were obtained in the temperature range of $25-200^{\circ} \mathrm{C}$, since no relaxation was expected to take place at temperatures in the range from -60 to $25^{\circ} \mathrm{C}$, and are displayed in Figure 3.12. The measurements with the H30 samples could not be performed because they broke when being clamped. The main relaxation progressively shifts to higher temperatures and broadens becoming more asymmetric with the increase in the silica content. At the same time, the maximum in $\tan \delta$ and the area under its peak decrease. In addition, the rubbery plateau modulus increases as the silica content increases. The temperatures of the maxima in $\tan \delta, T_{\alpha}$, and the storage moduli of the samples at $150^{\circ} \mathrm{C}, E_{150^{\circ} \mathrm{C}}$, have been represented in Figure 3.13 as a function of the silica content. The $T_{\alpha}$ increases linearly with the increase of the silica content. The $E_{150^{\circ} \mathrm{C}}$ values for PEMA, PHEA and H00 are 2.30, 2.27 and 1.10 MPa, respectively. This plateau modulus does not vary significantly up to $10 \mathrm{wt} \%$ of silica, when it starts to increase steeply, following an exponential tendency. 

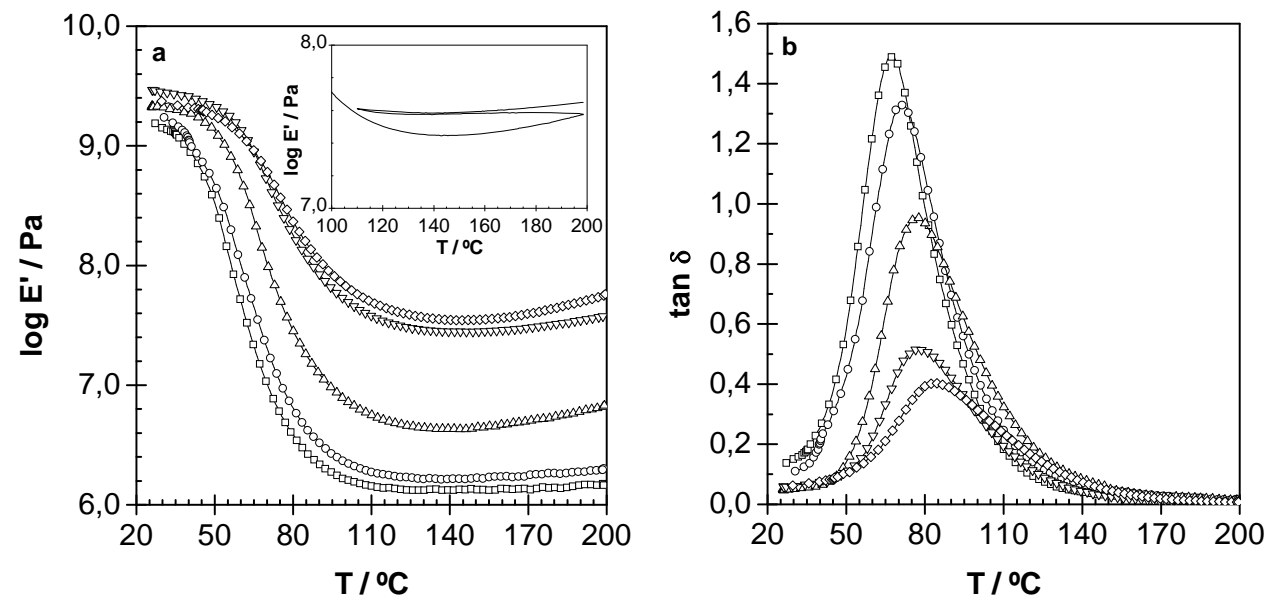

Figure 3.12 Temperature dependence of (a) the storage modulus, $E^{\prime}$, and (b) loss tangent, $\tan \delta$, for: $(\square) \mathrm{H} 00,(\bigcirc) \mathrm{H} 05,(\triangle) \mathrm{H} 10,(\nabla) \mathrm{H} 15$ and $(\diamond) \mathrm{H} 20$. Insert in (a): evolution of $E$ ' with a cycling temperature program of a first heating until $200^{\circ} \mathrm{C}$, an immediate cooling until $110^{\circ} \mathrm{C}$ and a reheating, for H15.

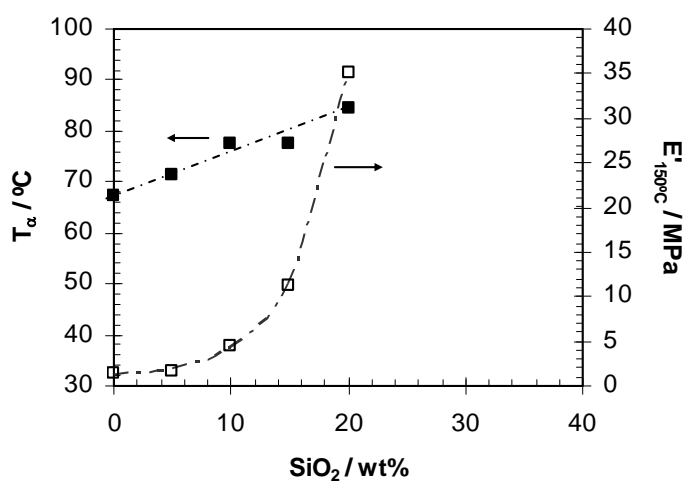

Figure 3.13 Dependence of $(\boldsymbol{\square})$ the temperature of the maximum loss tangent, $T_{\alpha}$, and $(\square)$ storage modulus at $150^{\circ} \mathrm{C}, E_{150^{\circ} \mathrm{C}}^{\prime}$, obtained from DMS measurements, with the silica content; (---) exponential fitting for $E^{\prime}{ }_{150^{\circ} \mathrm{C}}$.

At temperatures above $150^{\circ} \mathrm{C}$ the storage modulus of the $\mathrm{H} 10, \mathrm{H} 15$ and $\mathrm{H} 20$ hybrids increases slightly (approximately 1.5-fold). This effect has been reported in 
the literature ${ }^{[91]}$ and attributed to molecular motions at high temperatures allowing uncompleted sol-gel reactions to continue. In order to confirm this hypothesis, the $\mathrm{H} 15$ specimen was allowed to cool to $120^{\circ} \mathrm{C}$ and rescanned again. The thermogram obtained is inserted in Figure 3.12 (a) and shows that it is irreversible, i.e. the modulus maintains its value when cooling and increases but to a lesser extent when rescanning.

\subsubsection{Specific volume}

The dependence of the specific volume of the nanocomposites, $v$, on the silica content is shown in Figure 3.14. Error bars representing the standard deviation are included, but are the size of the symbols used in the plot.

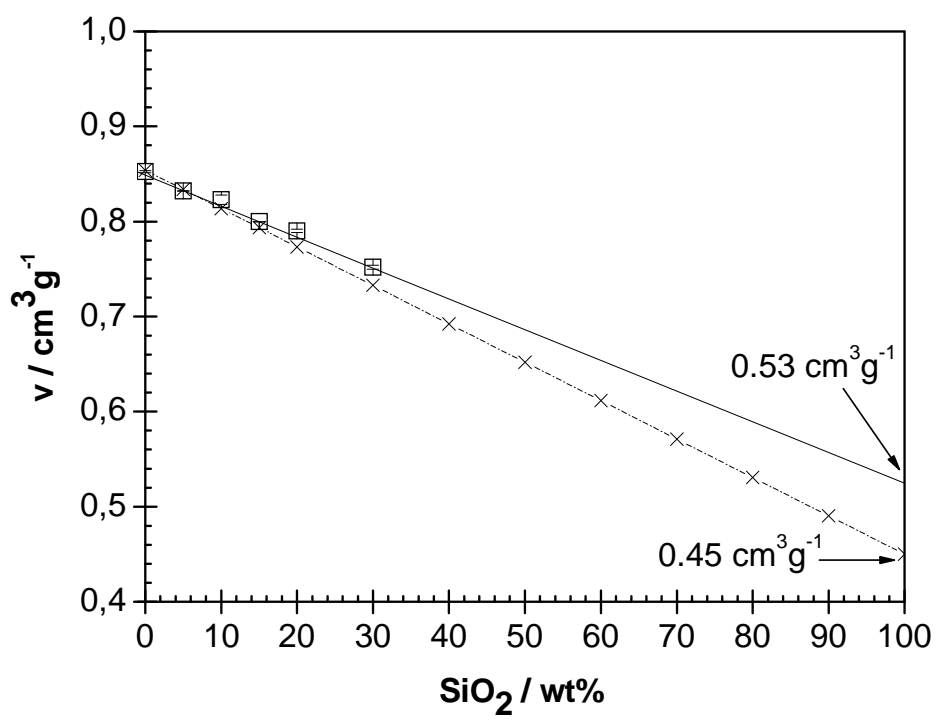

Figure $3.14(\square)$ Specific volume of the nanocomposites, $v$, as a function of the silica content, (--) linear regression and extrapolation for a sol-gel pure $\mathrm{SiO}_{2}$, $(X)$ specific volume predicted from the specific volumes of pure PEMA, PHEA and $\mathrm{SiO}_{2}$ glass obtained by curing, $v_{\text {theor }}$. 
The obtained values for PEMA and PHEA polymers are 0.89 and $0.77 \mathrm{~cm}^{3} \mathrm{~g}^{-1}$, respectively. The specific volume decreases linearly with the silica content from 0.85 to $0.75 \mathrm{~cm}^{3} \mathrm{~g}^{-1}$. Specific volume data considering the most efficient packing of the phases with no interstitial vacancies, i.e., all the silica network pores occupied by the organic polymer chains, $v_{\text {theor }}$, have been calculated as the ideal specific volumes, and represented. For this purpose, the specific volumes of PEMA and PHEA here obtained, a specific volume of $0.45 \mathrm{~cm}^{3} \mathrm{~g}^{-1}$ for pure silica glass obtained elsewhere by curing at $900^{\circ} \mathrm{C}^{[70]}$, and their corresponding mass fractions have been considered.

\subsubsection{Surface tension}

Table 3.1 lists the average water contact angles, $\theta_{w}$, and the surface tensions, with their dispersive and polar components. The polarity of the surface has been calculated for the different samples as the polar contribution divided by the surface tension, $\gamma_{s}^{p} / \gamma_{s}$, and is also arranged in Table 3.1.

\begin{tabular}{lccccc}
\hline Sample & $\boldsymbol{\theta}_{\boldsymbol{w}}\left({ }^{\mathbf{0}}\right)$ & $\gamma_{s}\left(\mathrm{mNm}^{-1}\right)$ & $\gamma_{s}^{p}\left(\mathrm{mNm}^{-1}\right)$ & $\gamma_{s}{ }^{d}\left(\mathrm{mNm}^{-1}\right)$ & $\gamma_{s}^{p} / \gamma_{s}$ \\
\hline PEMA & $82.6 \pm 1.6$ & 33.4 & 6.7 & 26.7 & 0.20 \\
PHEA & $96.1 \pm 3.9$ & 24.7 & 9.8 & 14.9 & 0.39 \\
H00 & $91.8 \pm 2.3$ & 26.1 & 3.9 & 22.2 & 0.15 \\
H05 & $92.0 \pm 1.6$ & 23.2 & 4.9 & 18.3 & 0.21 \\
H10 & $80.1 \pm 2.9$ & 31.9 & 9.1 & 22.8 & 0.28 \\
H15 & $76.5 \pm 1.4$ & 34.0 & 9.9 & 24.2 & 0.29 \\
H20 & $76.8 \pm 4.1$ & 31.2 & 11.6 & 19.6 & 0.37 \\
H30 & $90.5 \pm 2.2$ & 24.5 & 5.2 & 19.3 & 0.10 \\
\hline
\end{tabular}

Table 3.1 Water contact angles, $\theta_{w}$, surface tensions, $\gamma_{s}$, with polar, $\gamma_{s}^{p}$, and dispersive, $\gamma_{s}^{d}$, components, and polarity of the surfaces, $\gamma_{s}^{p} / \gamma_{s}$. 
The water contact angle of the H05 surface is identical to that of the copolymer, decreases for the intermediate silica contents and increases again for the H30 surface, taking again a value similar to that of the copolymer.

The surface tension of PHEA is lower than that of PEMA, due to a decrease in the dispersive component, the polar component being slightly higher. The surface tension of the copolymer takes an intermediate value between both of the homopolymers, with a dispersive component between those of them, but with the polar component lower. Concerning the hybrids, the surface tension slightly decreases when adding a $5 \mathrm{wt} \%$ of silica, then increases taking a maximum around the $15 \mathrm{wt} \%$ of silica and decreases afterwards. Both dispersive and polar components follow similar tendencies when increasing the amount of silica.

\subsubsection{Differential Scanning Calorimetry}

Figure 3.15 displays the normalized heat flow during the second heating of the DSC measurements, referred to each sample mass. After obtaining the corresponding specific heat capacity curves against temperature, the glass transition temperature, $T_{g}$, has been calculated for each composition as the inflexion point of the curve. The width of the glass transition, $\Delta T_{g}$, has been determined by the temperature interval defined by the intersections of the tangent line at the inflexion point with those of the extrapolated glass and liquid lines. The specific heat capacity increment at the glass transition measured per gram of hybrid, $\Delta c_{p}$, has been obtained as the difference between these intersections. The fraction of hybrid able to undergo conformational motions at the glass transition, $x$, and the fraction of copolymer in the hybrid able to undergo conformational motions at the glass transition, $x$, have been calculated as:

$$
x=\frac{\Delta c_{p}}{\Delta c_{p}^{\text {copolymer }}} \quad x^{\prime}=\frac{\Delta c_{p}}{\Delta c_{p}^{\text {copolymer }} \cdot x_{\text {copolymer }}}=\frac{x}{x_{\text {copolymer }}}
$$




\section{Results}

where $x_{\text {copolymer }}$ is the mass fraction of copolymer in the hybrid. These four parameters have been represented in Figure 3.16.

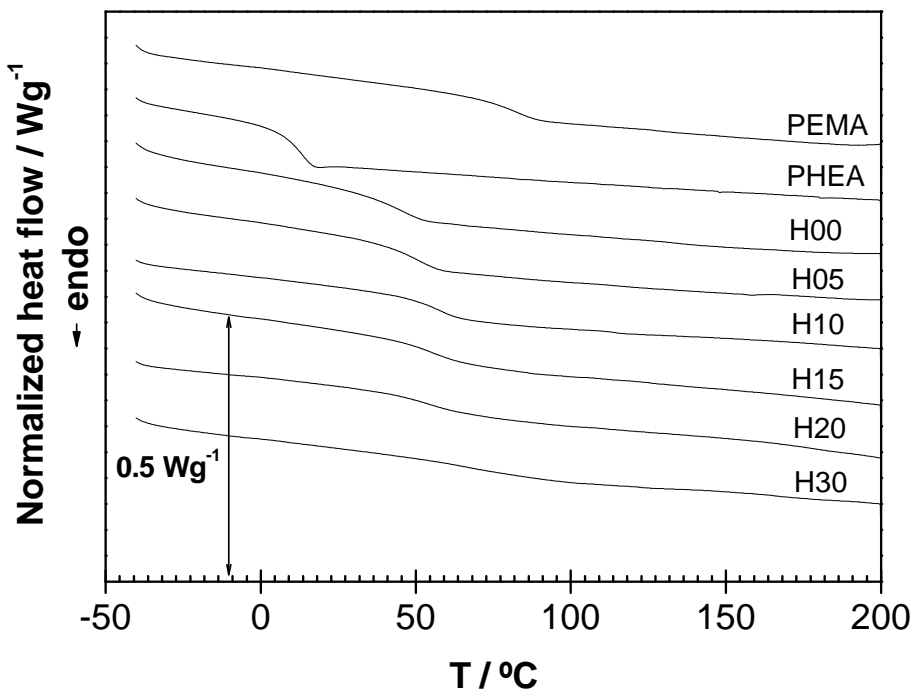

Figure 3.15 Normalized heat flow during the second calorimetric heating.
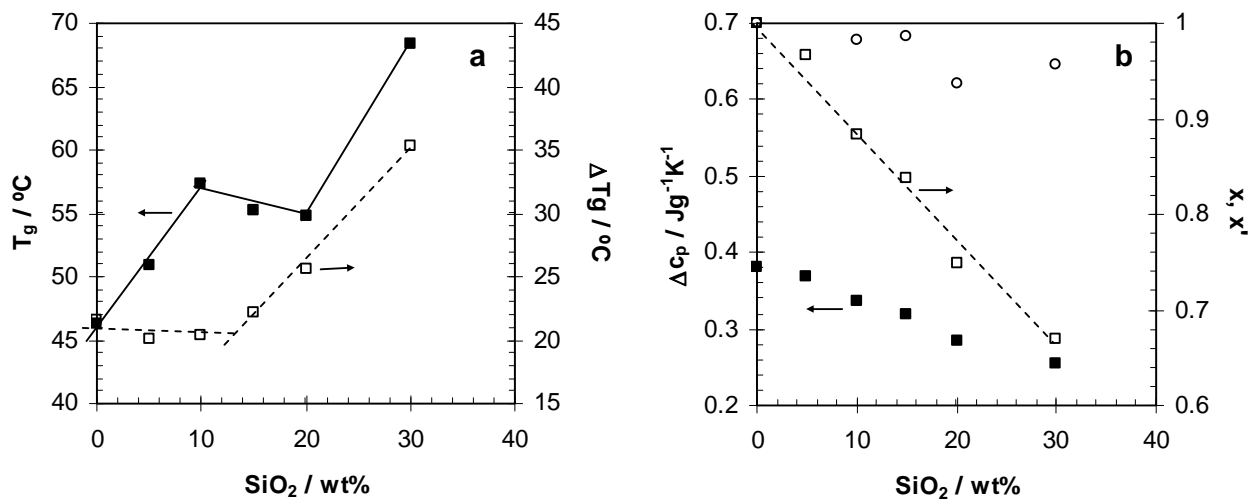

Figure 3.16 (a): (ם) DSC glass transition temperature, $T_{g}$, and ( $\square$ ) width of

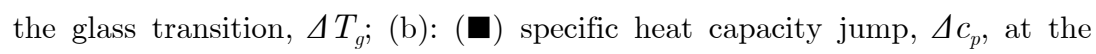
glass transition and $(\square)$ fraction of the hybrid able to undergo the glass transition process, $x$, and $(\bigcirc)$ fraction of the copolymer able to undergo the glass transition process, $x^{\prime}$, as a function of the silica content. 
Both PEMA and PHEA are amorphous polymers with glass transition temperatures of 81.87 and $11.37^{\circ} \mathrm{C}$, respectively. The single glass transition of the copolymer lies between those of the homopolymers, shifts to higher temperatures, and broadens tending to vanish with the increase of the silica content, being hardly discernible for the $\mathrm{H} 30$ hybrid. The $T_{g}$ of the copolymer, $46.33^{\circ} \mathrm{C}$, is somewhat lower than that estimated by the Fox equation ${ }^{[147]}$ :

$$
\frac{1}{T_{g}}=\sum \frac{w_{i}}{T_{g i}}
$$

where $w_{i}$ is the mass fraction of homopolymer $i$ and $T_{g i}$ its glass transition temperature. This equation predicts a value of $57.30^{\circ} \mathrm{C}$. The $T_{g}$ of the copolymer increases $10^{\circ} \mathrm{C}$ when adding a $10 \mathrm{wt} \%$ of silica, then remains stable up to $20 \mathrm{wt} \%$, and increases $10^{\circ} \mathrm{C}$ more for the $30 \mathrm{wt} \%$ of silica. The $\Delta T_{g}$ measures $20.74^{\circ} \mathrm{C}$ for PEMA, $9.87^{\circ} \mathrm{C}$ for PHEA and $21.75^{\circ} \mathrm{C}$ for the copolymer. For the hybrids it takes values similar to the copolymer up to $10 \mathrm{wt} \%$ of silica, when it starts to increase as the glass transition broadens. The $\Delta c_{p}$ for PEMA is $0.31 \mathrm{Jg}^{-1} \mathrm{~K}^{-1}, 0.44 \mathrm{Jg}^{-1} \mathrm{~K}^{-1}$ for PHEA and $0.38 \mathrm{Jg}^{-1} \mathrm{~K}^{-1}$ for the copolymer. It decreases linearly with the silica content. The fraction of the hybrids undergoing conformational motions at the glass transition decreases linearly from unity for the copolymer to 0.67 for H30, i.e., the fraction of copolymer in the hybrids able to participate in the glass transition is always close to unity.

\subsubsection{Compression tests}

The compressive elastic moduli, $E_{\text {bulk }}$, obtained from the stress-strain curves, are shown in Figure 3.17 (a) for some samples as an example, and are represented as a function of the silica content in Figure 3.17 (b). The values obtained for the homopolymers are 4193 and $142 \mathrm{MPa}$ for PEMA and PHEA, respectively. The elastic modulus of the copolymer lies between those of the homopolymers, and 


\section{Results}

maintains similar values up to H15, from where it starts to increase. The elastic modulus of H30 is similar to that of PEMA.
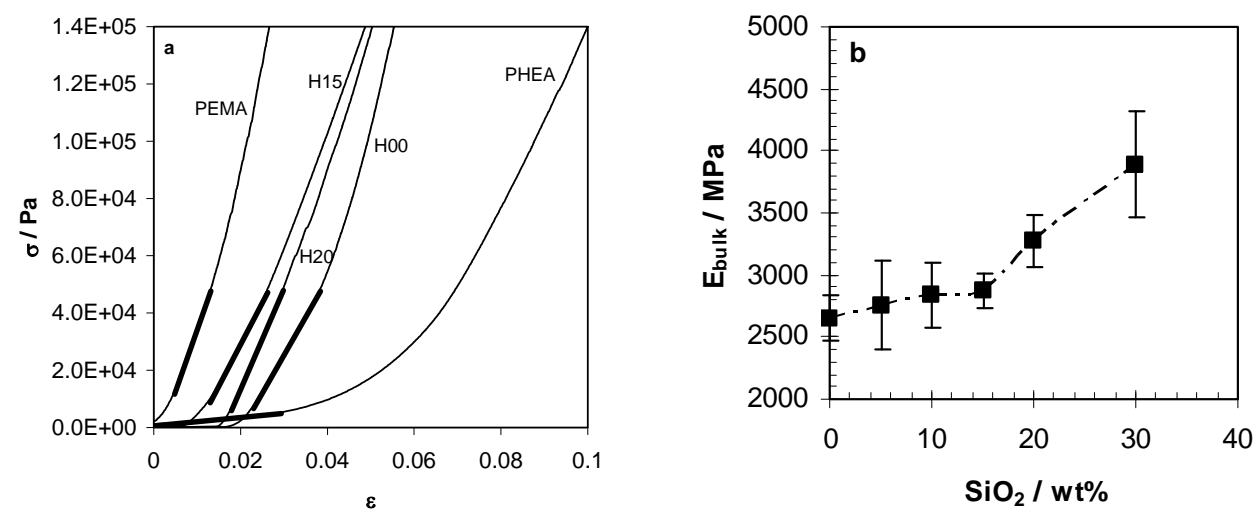

Figure 3.17 (a) Stress, $\sigma$,-strain, $\varepsilon$, curves for some samples indicating the interval where the elastic modulus has been calculated; (b) dependence of the compressive elastic moduli, $E_{b u l k}$, on the silica content. 


\subsection{Bioactivity of $\mathrm{P}(\mathrm{EMA}-\mathrm{co}-\mathrm{HEA}) / \mathrm{SiO}_{2}$ nanocomposites}

\subsubsection{Characterization of the apatite formed on the substrates in SBF}

\subsubsection{Scanning Electron Microscopy-Energy Dispersive Spectroscopy}

Figure 3.18 shows the SEM images of the different samples, after different times of immersion in SBF. After 7 days (SBF7), the PEMA surface presents small scattered deposits, and the PHEA surface exhibits plenty of precipitates, some of them squared or rectangular shaped. The copolymer surface is covered, though still with some imperfections, of typical needle-shaped crystals intricately intertwined forming typical porous cauliflower hydroxyapatite (HAp) structures $[38,53,60,94,104,105,112,115]$ with an average diameter around $1 \mu \mathrm{m}$, which merge as they grow to form a continuous uniform coating. The H05 surface is completely covered with these same structures, and H10, H15 and H20 even exhibit superposed scattered agglomerates of what seem to be an incipient second layer, and some plain structures anchored to the first coating by needle-like formations. The composition of these uppermost plain structures is the same as that of the cauliflowers below, as demonstrates the EDS spectrum in Figure 3.19. By contrast, only some dispersed smaller cauliflowers appeared on the H30 surface after 7 days, with lower average diameters (around $500 \mathrm{~nm}$ ). 

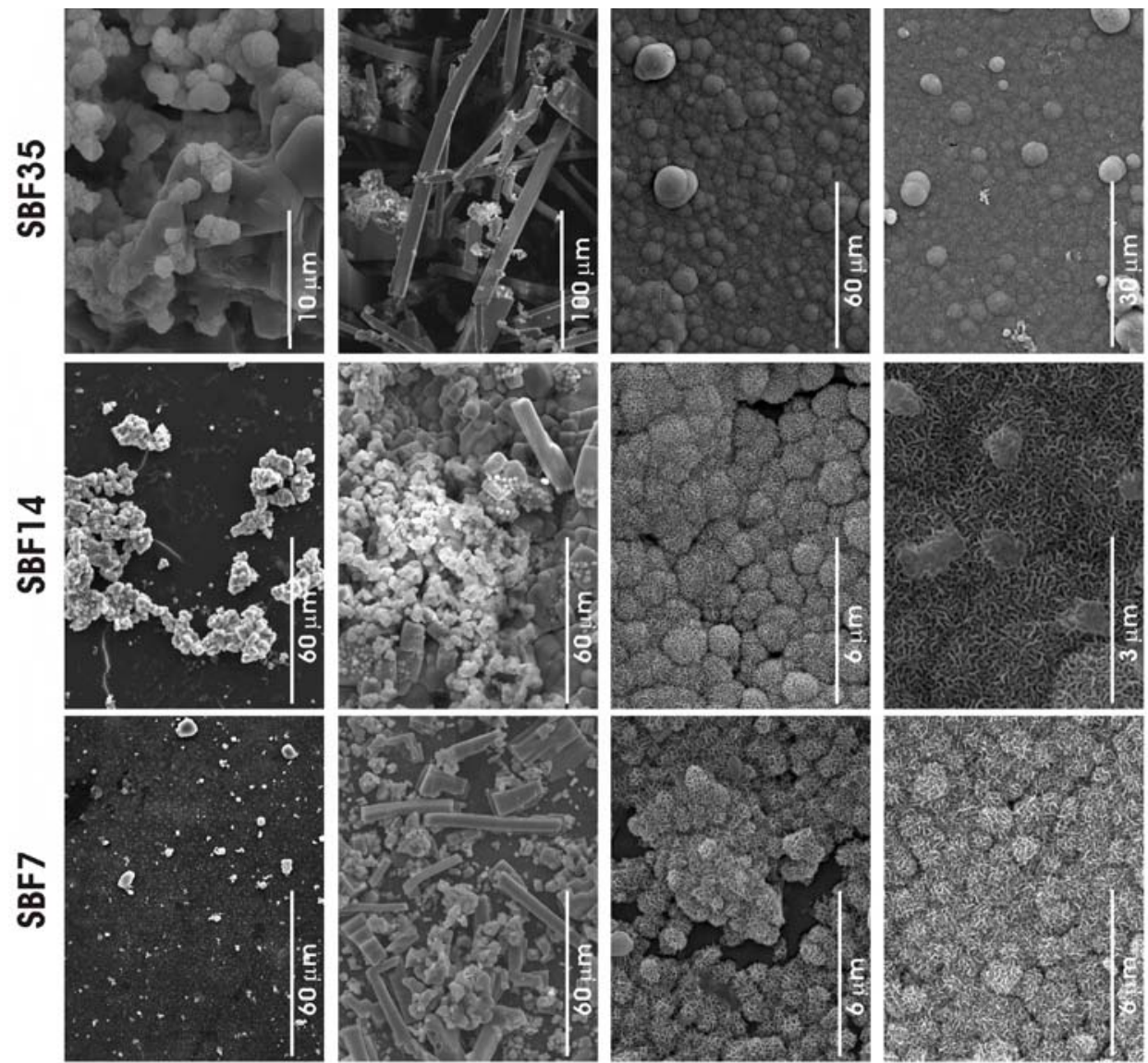

VWFd

$\forall$ JHd

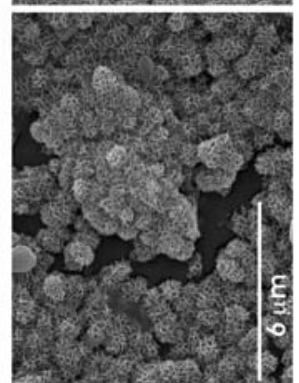

$\mathrm{OOH}$

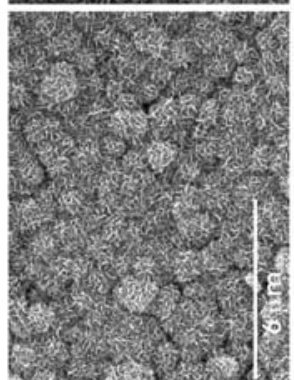

SOH 

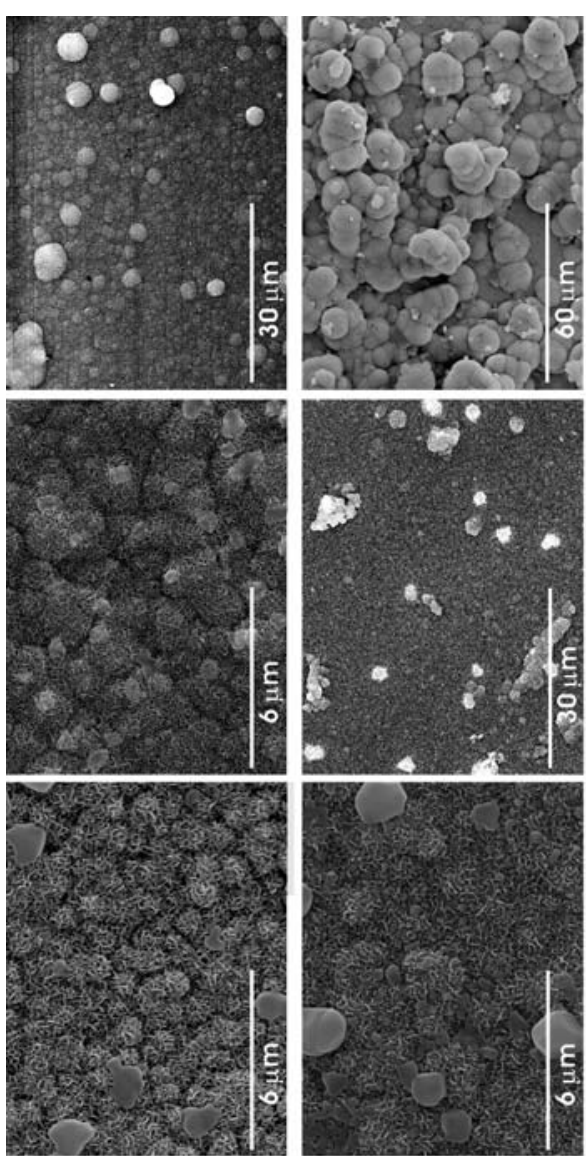

OLH
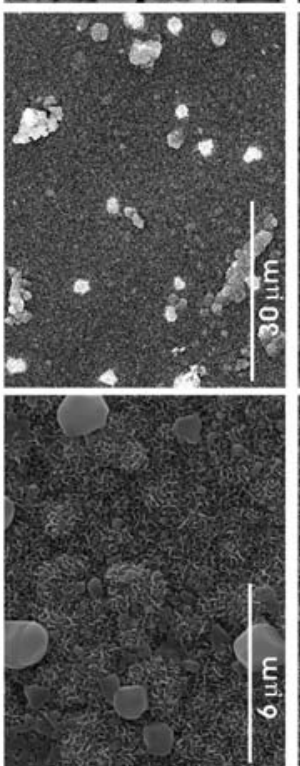

SLH
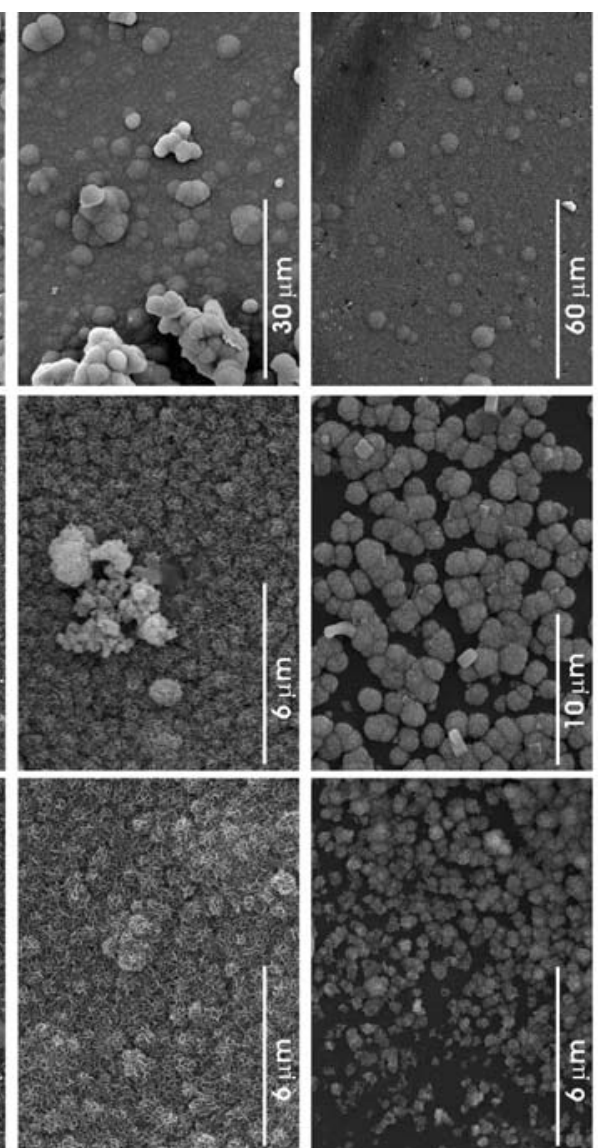

OZH

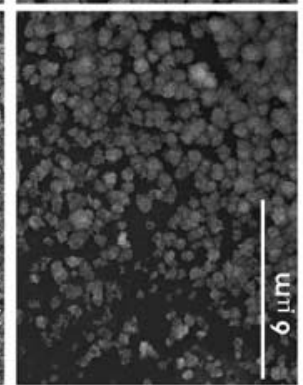

OEH 


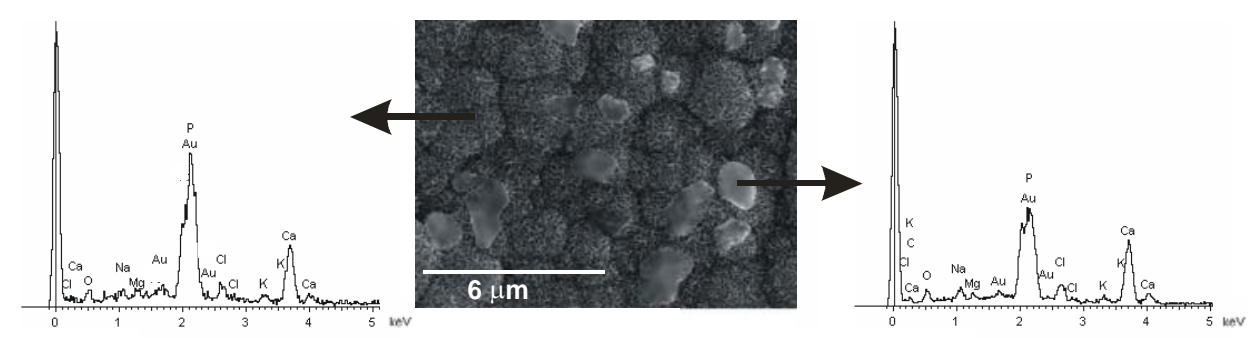

Figure 3.19 EDS spectra of the H10 hybrids after 14 days in SBF, obtained:

(a) on a cauliflowers zone, and (b) on a flat formation.

The soaking in $2 \times \mathrm{SBF}$ promoted the formation of deposits on the surface of PEMA, in combination with cauliflower structures. The EDS spectrum in Figure 3.20 (a) shows that the precipitates not in needle-like conformation are salts from the SBF, basically $\mathrm{NaCl}$. PHEA exhibits deposits in several layers, some of them with cauliflower structure, but the majority are rectangular shaped $\mathrm{NaCl}$ crystals (Figure 3.20 (b)). Regarding the copolymer, a continuous HAp layer mainly covered its surface after 14 days in SBF (SBF14), and completely after 35 days (SBF35).
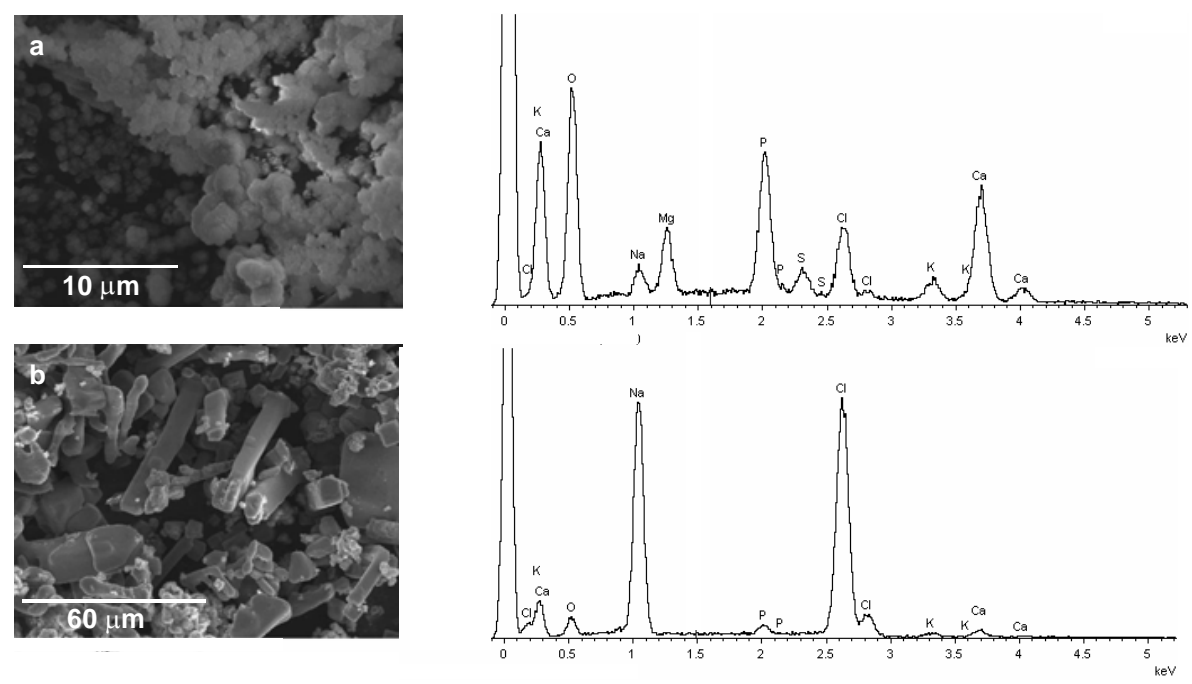

Figure 3.20 EDS spectra of: (a) PEMA and (b) PHEA samples after 14 days in $\mathrm{SBF}$. 
The HAp cauliflowers of H05, H10, H15 and H20 increased their diameters up to 1$2 \mu \mathrm{m}$ during the soaking in $2 \times \mathrm{SBF}$, while the plate formations progressively adopted needle-like conformations (Figure 3.21 (a)) and more agglomerates of cauliflowers precipitated in successive layers, as shown in the transversal cut of H15 after 35 days in SBF (Figure 3.21 (b)). The final thickness of the apatite coating is larger than $10 \mu \mathrm{m}$. These four samples display at the end of the test plain areas of merged HAp cauliflowers in combination with others with grape-like agglomerates of cauliflowers leading to very irregular topographies. They can be observed in the H15 SBF35 image in Figure 3.18. Some of these samples had to be sputter-coated with gold two or three times to avoid brightness and shadows in the SEM images. The H30 surface was not completely coated after 14 days in SBF; it became totally covered only by the end of the test, so there was no noticeable difference among the coated hybrids after 35 days of test. It was not possible to quantify the amount of HAp gravimetrically.
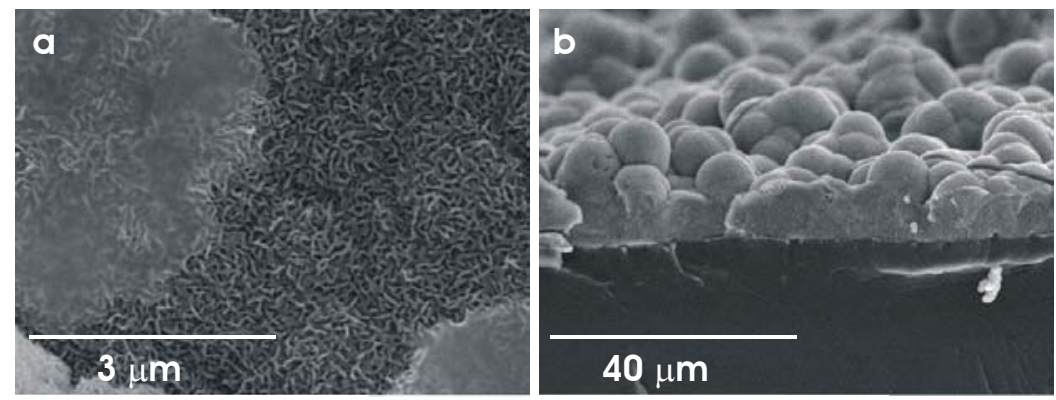

Figure 3.21 SEM images of: (a) the surface of H10 after 14 days in SBF; (b) the transversal fractured section of $\mathrm{H} 15$ after 35 days in SBF.

H00, H15 and H30 samples were soaked in SBF for shorter times: 1, 3 and 5 days in order to determine the precise induction times. The SEM images are shown in Figure 3.22. After 1 day, H00 and more H15 presented some dotted zones and scattered salt deposits, whereas H30 exhibited only scattered deposits. After 3 days, in H00 the distribution of nuclei and precipitates was more uniform, the H15 


\section{Results}

hybrid already showed some areas completely covered with small HAp cauliflowers, whereas only scattered deposits had precipitated on H30. After 5 days, the H15 surface was mainly covered with HAp cauliflowers, whereas the H00 presented nuclei and deposits, and H30 revealed only some deposits on the surface.
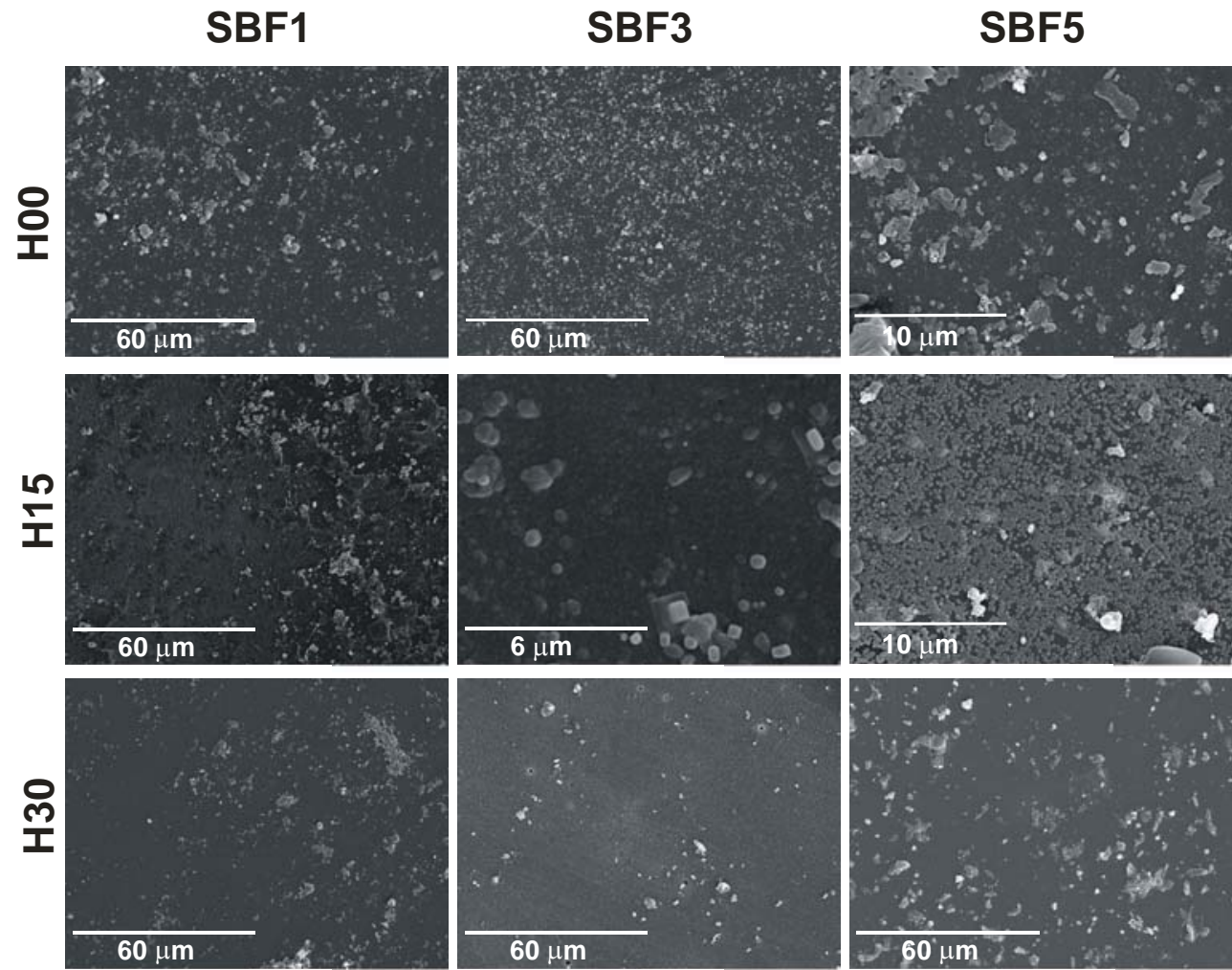

Figure 3.22 SEM images of the surfaces of the H00, H15 and H30 samples after immersion in SBF for short times: 1 day (SBF1), 3 days (SBF3), and 5 days (SBF5).

The results from the EDS spectra of the homopolymers have not been tabulated because the coatings of PHEA consist basically in $\mathrm{NaCl}$, which is the main component of the SBF solutions, and the EDS spectra of PEMA differ considerably depending on the analyzed zones, showing basically $\mathrm{Ca}$ and $\mathrm{P}$ in some zones, while 
$\mathrm{NaCl}$ in others. Figure 3.23 shows a typical EDS profile of the HAp coating of a hybrid. The main elements are $\mathrm{Ca}$ and $\mathrm{P}$, but other elements from the SBF like $\mathrm{Na}, \mathrm{Mg}, \mathrm{K}$ and $\mathrm{Cl}$ are also present. Silicon is observed in the EDS spectra after 7 days of immersion in SBF in all nanocomposites, it appears in some spectra after 14 days, but it is not detectable in any hybrid by EDS after 35 days in SBF. From the EDS results, the $\mathrm{Ca} / \mathrm{P}$ atomic ratio has been calculated in each case to be compared with that of the stoichiometric HAp $\left(\mathrm{Ca}_{10}\left(\mathrm{PO}_{4}\right)_{6}(\mathrm{OH})_{2}\right), \mathrm{Ca} / \mathrm{P}=1.67$, or physiological $\mathrm{HAp}, \mathrm{Ca} / \mathrm{P}=1.65$ value ${ }^{[54]}$, Table 3.2 . In general, the $\mathrm{Ca} / \mathrm{P}$ ratios are slightly lower than the physiological HAp ratio, not following any trend with the silica content. For short times, the $\mathrm{Ca} / \mathrm{P}$ values are quite heterogeneous, but they seem to increase in all cases, approximating to the ratio of physiological HAp with the immersion time. Considering the possibility of $\mathrm{Mg}^{2+}, \mathrm{Na}^{+}$and $\mathrm{K}^{+}$, replacing partially the $\mathrm{Ca}^{2+}$ ion in the apatite, the $(\mathrm{Ca}+\mathrm{Na}+\mathrm{Mg}+\mathrm{K}) / \mathrm{P}$ atomic ratios have been calculated and are also listed in Table 3.2. Initially, there is a considerable difference between $\mathrm{Ca} / \mathrm{P}$ and $(\mathrm{Ca}+\mathrm{Na}+\mathrm{Mg}+\mathrm{K}) / \mathrm{P}, \mathrm{Na}^{+}$and $\mathrm{Mg}^{2+}$ being the main contributors. Longer times of immersion in $\mathrm{SBF}$ lead to more homogeneous $(\mathrm{Ca}+\mathrm{Na}+\mathrm{Mg}+\mathrm{K}) / \mathrm{P}$ results, and closer to those of $\mathrm{Ca} / \mathrm{P}$.
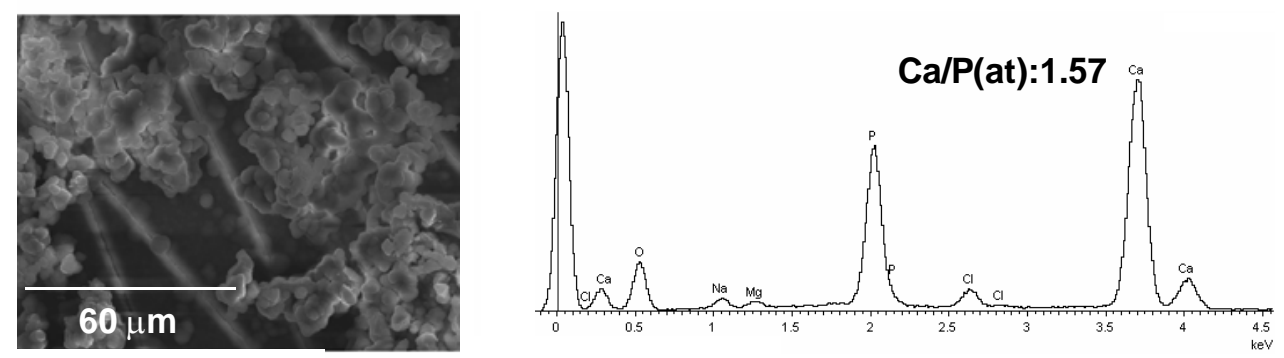

Figure 3.23 EDS spectrum of the H20 sample after 35 days in SBF. 
3. Results

\begin{tabular}{|c|c|c|c|c|c|c|}
\hline & $\frac{C a}{P}$ & $\frac{\mathrm{Ca}+\mathrm{Na}+\mathrm{Mg}+\mathrm{K}}{P}$ & $\frac{N a}{C a}$ & $\frac{M g}{C a}$ & $\frac{K}{C a}$ & $\frac{C l}{P}$ \\
\hline & \multicolumn{6}{|c|}{ SBF7 } \\
\hline H00 & 1.34 & 1.85 & 0.31 & 0.07 & 0.00 & 0.22 \\
\hline H05 & 1.47 & 1.62 & 0.07 & 0.04 & 0.00 & 0.06 \\
\hline H10 & 1.26 & 1.51 & 0.14 & 0.05 & 0.00 & 0.09 \\
\hline H15 & 1.48 & 1.80 & 0.11 & 0.07 & 0.04 & 0.26 \\
\hline H20 & 1.53 & 2.54 & 0.47 & 0.16 & 0.04 & 0.90 \\
\hline \multirow[t]{2}{*}{ H30 } & 1.58 & 1.94 & 0.06 & 0.00 & 0.00 & 0.07 \\
\hline & \multicolumn{6}{|c|}{ SBF14 } \\
\hline H00 & 1.38 & 1.68 & 0.16 & 0.04 & 0.01 & 0.20 \\
\hline H05 & 1.35 & 1.48 & 0.05 & 0.05 & 0.00 & 0.02 \\
\hline H10 & 1.37 & 1.96 & 0.20 & 0.15 & 0.08 & 0.37 \\
\hline H15 & 1.33 & 1.96 & 0.34 & 0.08 & 0.04 & 0.35 \\
\hline H20 & 1.25 & 1.37 & 0.03 & 0.05 & 0.00 & 0.06 \\
\hline \multirow[t]{2}{*}{ H30 } & 1.39 & 1.60 & 0.11 & 0.04 & 0.00 & 0.16 \\
\hline & \multicolumn{6}{|c|}{ SBF35 } \\
\hline H00 & 1.48 & 1.73 & 0.12 & 0.04 & 0.00 & 0.15 \\
\hline H05 & 1.44 & 1.61 & 0.07 & 0.04 & 0.00 & 0.07 \\
\hline H10 & 1.50 & 1.75 & 0.11 & 0.05 & 0.00 & 0.14 \\
\hline H15 & 1.49 & 1.68 & 0.07 & 0.05 & 0.01 & 0.08 \\
\hline H20 & 1.57 & 1.79 & 0.10 & 0.04 & 0.00 & 0.12 \\
\hline H30 & 1.65 & 1.87 & 0.05 & 0.04 & 0.05 & 0.21 \\
\hline
\end{tabular}

Table 3.2 $\mathrm{Ca} / \mathrm{P},(\mathrm{Ca}+\mathrm{Na}+\mathrm{Mg}+\mathrm{K}) / \mathrm{P}, \mathrm{Na} / \mathrm{Ca}, \mathrm{Mg} / \mathrm{Ca}, \mathrm{K} / \mathrm{Ca}$ and $\mathrm{Cl} / \mathrm{P}$ atomic ratios of the HAp formed on the hybrids after different times in SBF. 


\subsubsection{Fourier-Transform Infrared Analysis}

Figure 3.24 shows the FTIR spectra of some of the samples after the different times of immersion in SBF. In the copolymer and the nanocomposites, the characteristic peaks corresponding to the composition of the hybrids disappear between 7 and 14 days, and a regular spectrum appears. The well defined strong peak at $1700 \mathrm{~cm}^{-1}$ corresponding to the $\mathrm{C}=\mathrm{O}$ bonds of the carboxyl groups and the complex spectra between 1500 and $650 \mathrm{~cm}^{-1}$ of the copolymer disappear. In the H15 and H30 hybrids, the intensity of the peaks at 1060-1100 and $950 \mathrm{~cm}^{-1}$ attributed to Si-O-Si and Si-OH bonds of the silica phase, respectively $[90,104,108,109,112,122,145]$, decrease with the immersion time in SBF, until FTIR cannot detect the original surface. It occurs similarly with the rest of the hybrids. 


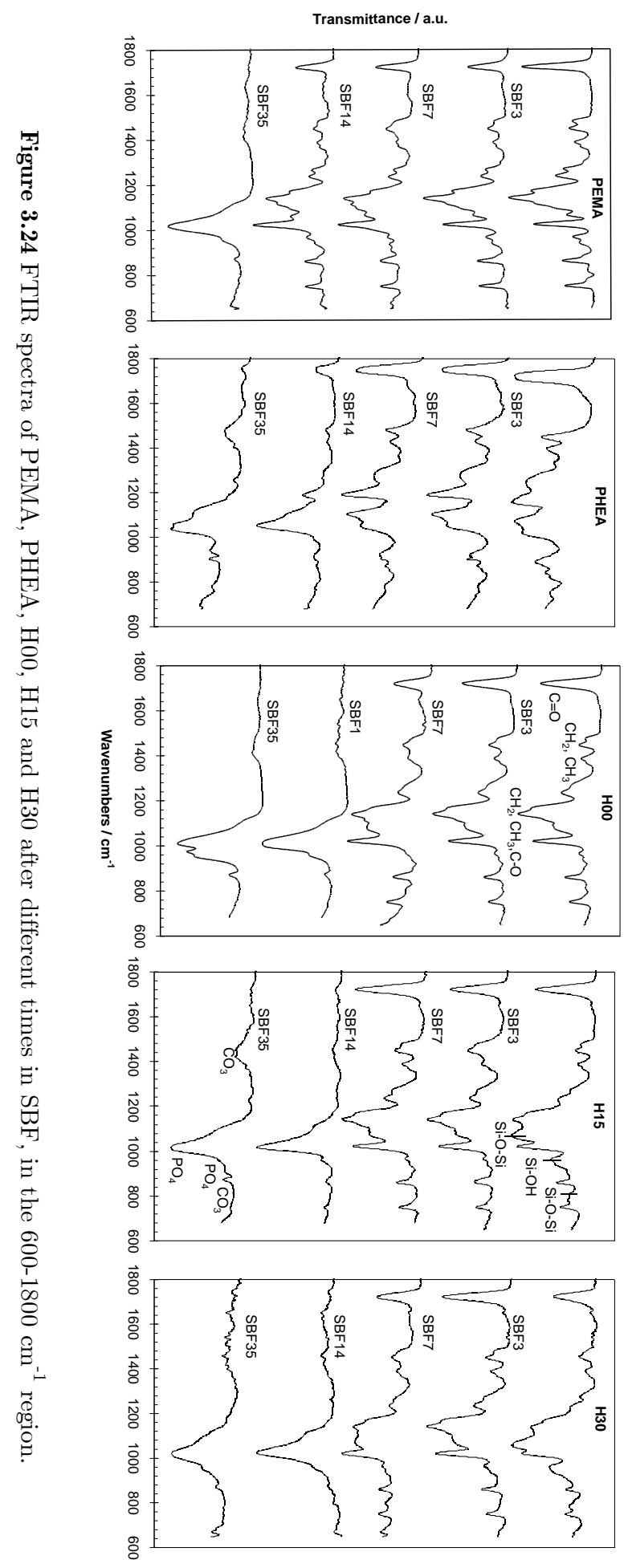


After prolonged soaking, the apatite peaks become the only constituents of the FTIR spectra, as the apatite grows in successive layers and completely covers the surfaces of the samples. The new common spectrum presents a well-pronounced peak at $1020 \mathrm{~cm}^{-1}$, a wide peak at $1430-1470 \mathrm{~cm}^{-1}$, and two minor peaks at 880 and $970 \mathrm{~cm}^{-1}$. The peaks at 1020 and $970 \mathrm{~cm}^{-1}$ are attributed to the $\mathrm{PO}_{4}{ }^{3-}$ ion (asymmetric and symmetric stretching), and those at 1430-1470 and $875 \mathrm{~cm}^{-1}$ are ascribed to the $\mathrm{CO}_{3}{ }^{2-}$ ion (out of plane and stretching mode) [39,42,54,67,90,93,104] , partially occupying $\mathrm{PO}_{4}{ }^{3-}$ sites in the apatite ${ }^{[54]}$. Characteristic HAp bands correspond to $\mathrm{PO}_{4}{ }^{3-}$ groups $\left(1092,1036,962,602,567,472 \mathrm{~cm}^{-1}\right)$ but also to $\mathrm{OH}^{-}$ groups $\left(3570 \mathrm{~cm}^{-1}\right){ }^{[148]}$. The characteristic hydroxyl band does not appear here in any spectrum. The peak due to the hydroxyl groups in the copolymer did not appear, either (Fig. 3.1, p. 46). This is why the spectra have been represented in the $1800-600 \mathrm{~cm}^{-1}$ range in Figure 3.24. For the PEMA sample, the characteristic HAp spectrum does show up only after 35 days SBF immersion, and for the PHEA sample it never happens to appear, the spectrum having always HAp absorption bands overlapped with polymeric bands.

\subsubsection{X-Ray Diffraction}

Figure 3.25 shows the X-ray diffraction patterns of H00, H15 and H30 before soaking in SBF and after 14 and 35 days in SBF. After 14 days in SBF, the peaks corresponding to the coatings are poorly resolved and the broad band corresponding to the hybrid predominates in the three spectra $\left(10-25^{\circ}\right)$. After 35 days, the broad peak at 32 to $34^{\circ}$ and the peak at around $26^{\circ}$ attributed to XRD HAp crystals ${ }^{[40,50,54,60,61,93,101,102]}$ are well defined. The intensity of these peaks decreases in the order: $\mathrm{H} 15>\mathrm{H} 30>\mathrm{H} 00$. The broad band corresponding to the amorphous hybrid in $\mathrm{H} 15$ has completely vanished, it is slightly noticeable in H00, but in H30 it maintains the initial shape and overlaps with the HAp peaks. 

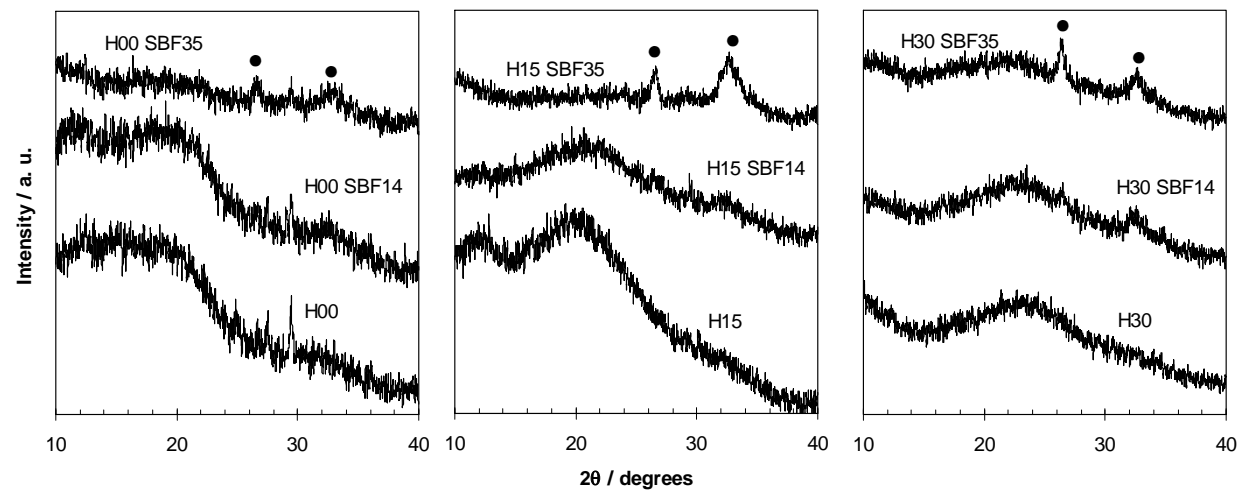

Figure 3.25 XRD spectra of H00, H15 and H30 and after 14 and 35 days in SBF.

\subsubsection{Structural changes of the nanocomposites in the SBF}

\subsubsection{Energy Dispersive Spectroscopy}

In order to analyze the structural changes taking place in the hybrids upon immersion in a SBF solution, and the possible influence of silica, H15 and H30 samples previously soaked in SBF for 35 days were fractured and EDS spectra were obtained considering different successive in-depth bands of approximately $8 \mu \mathrm{m}$ of thickness from the interface HAp-nanohybrid to the interior of the samples, as the sketch of Figure 3.26 shows. Figure 3.27 displays the EDS spectra of the fractured H15 SBF35.

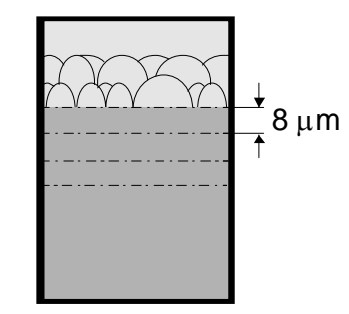

Figure 3.26 Sketch of the successive in-depth bands for EDS analysis. 

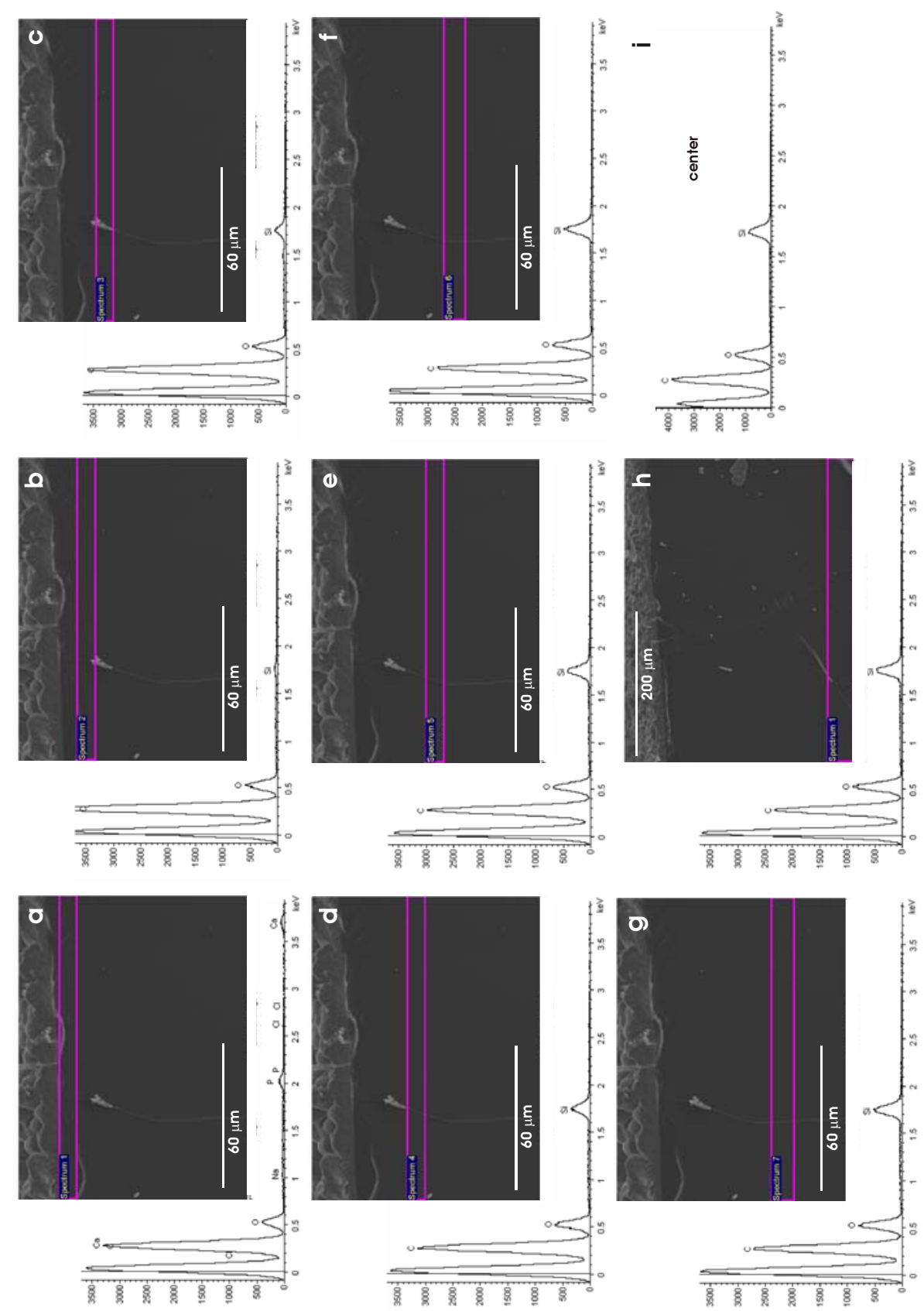

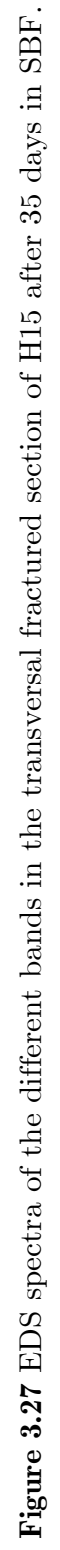




\section{Results}

The silicon content progressively increases from the surface to the interior of the sample. The correlation of the silica contents calculated from the EDS silicon contents (neglecting the amount of hydrogen in the copolymer and in the silanol groups bounding the silica network and the carbon coating of the samples for the EDS measurements) with the position relative to the surface has been represented in Figure 3.28. For H15, silica is absent in the first $10 \mu \mathrm{m}$ closest to the surface, then the silica content increases linearly up to $48 \mu \mathrm{m}$ in depth, where it reaches a value of $14.92 \mathrm{wt} \%$, similar to that found in the centre of the fracture $(13.46 \mathrm{wt} \%)$, and those found previously in the original H15 samples on the surface (15.09 wt\%) and in the interior (15.33 wt\%) by EDS (Fig. 3.8, p. 52).

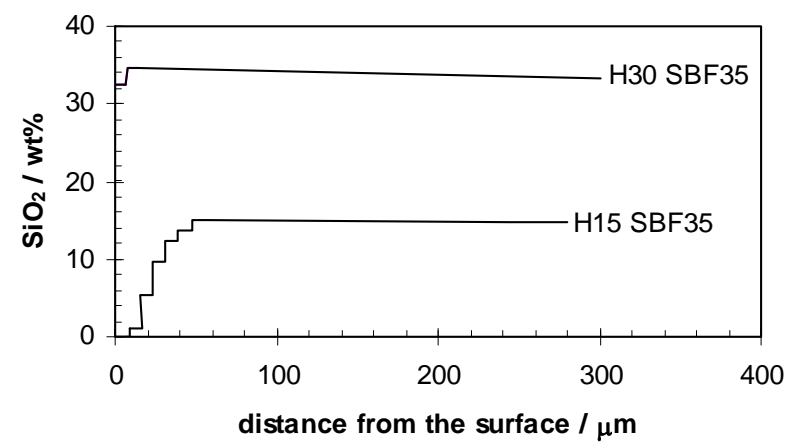

Figure 3.28 Correlation of the silica content with the position relative to the surface in $\mathrm{H} 15$ and H30 samples after 35 days in SBF.

Figure 3.29 displays the EDS spectra obtained by bands in a fractured H15 sample after 35 days in SBF but at higher magnifications and closer to the surface. The spectra demonstrate that silica is nearly absent in the interface (only traces of silica can be detected in some spectra) and that the HAp layers penetrate in the material, forming a very cohesive coating. The coating adhered to the sample strongly and the apatite layer could not be peeled off from the surface by a tapedetaching test. $\mathrm{Ca}, \mathrm{P}, \mathrm{Na}, \mathrm{Mg}$ and $\mathrm{Cl}$ elements could be detected up to $3.5 \mu \mathrm{m}$ in depth, the $\mathrm{Ca} / \mathrm{P}$ ratio being 1.36 up to $3 \mu \mathrm{m}$. The spectra of a fractured $\mathrm{H} 15$ sample after 7 days in SBF were also obtained (data not shown). The gradient of silica covered only the first $\mu \mathrm{m}$ in-depth band, and elements from the HAp layer were not detected in the interior of the sample. 


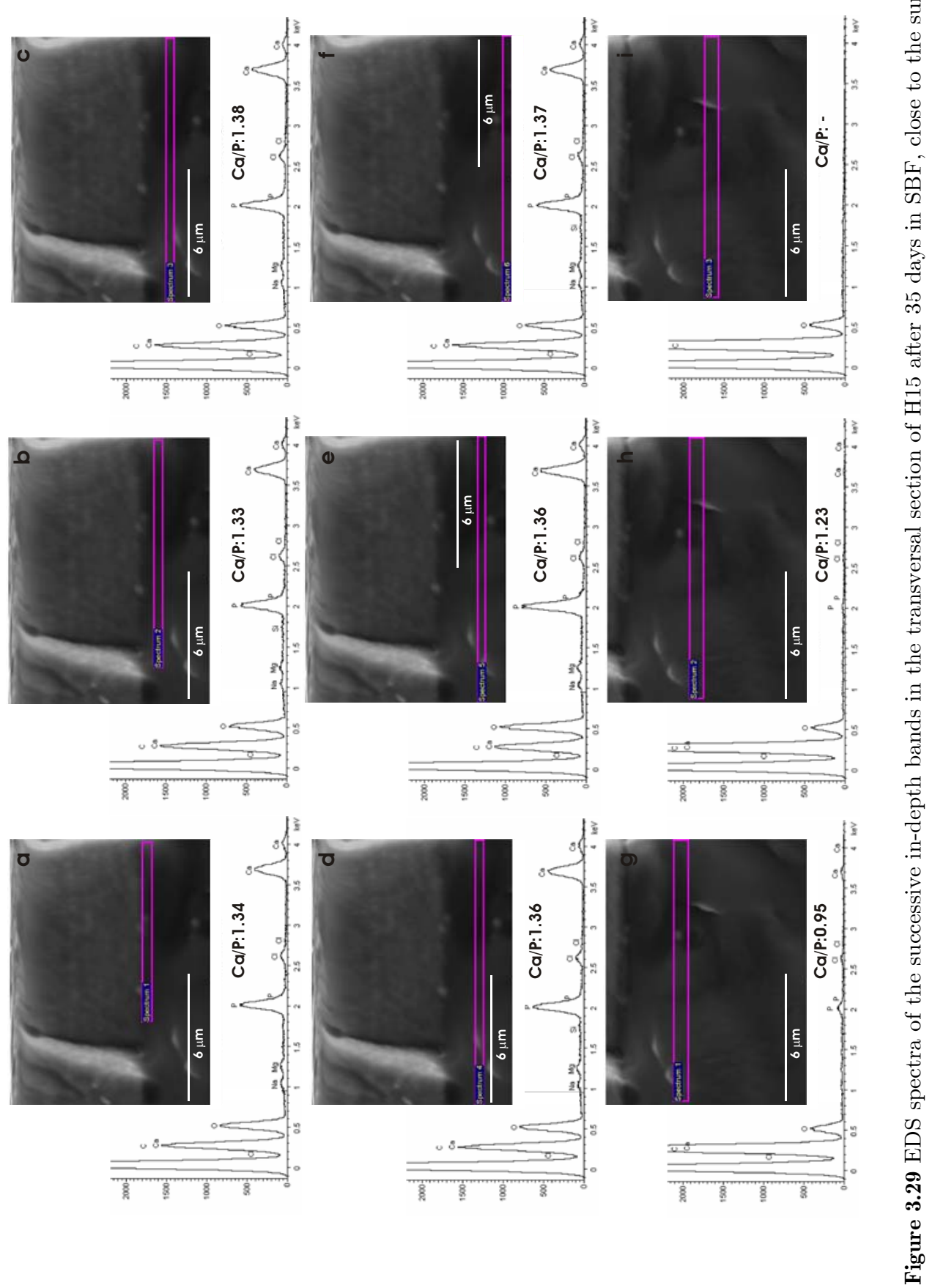




\section{Results}

Figure 3.30 shows the EDS spectra of the successive in-depth bands considered in the transversal section of H30 after 35 days in SBF. The silica content close to the surface (32.46 wt\%) (Figure 3.28) is similar to that in the interior (33.41 wt\%), and those found in the original H30 samples on the surface (28.45 wt\%) and in the interior (24.87 wt\%) by EDS (Fig. 3.8, p. 52). In this case, the HAp coating is not adhered to the surface as a continuous layer.

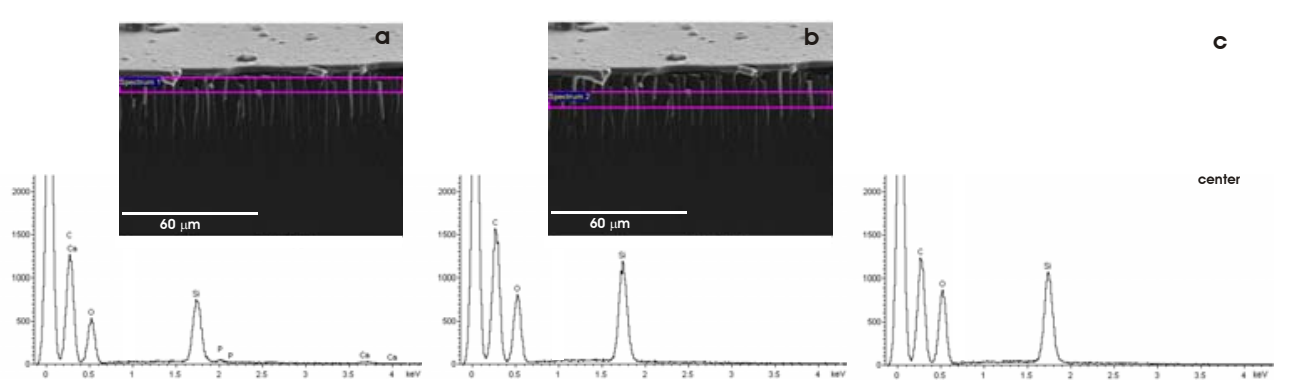

Figure 3.30 EDS spectra of the different bands in the transversal fractured section of H30 after 35 days in SBF. 


\title{
3.4 Surface treatments as a means of reducing the apatite nucleation induction times
}

3.4.1 Surface structural changes of the substrates due to the $\mathrm{NaOH}$ treatment

\begin{abstract}
After the immersion in the $\mathrm{NaOH}$ solution at $50^{\circ} \mathrm{C}$ for $48 \mathrm{~h}$, the $\mathrm{H} 00$ and $\mathrm{H} 15$ samples remained optically transparent, but those of H30 whitened. In addition, the H15 and H30 samples swelled and bent. Thus, it was not possible to obtain FTIR spectra of these samples.
\end{abstract}

\subsubsection{Scanning Electron Microscopy}

Figure 3.31 (column headed $\mathrm{NaOH}$ ) displays the SEM images of the NaOH-treated dry samples before their immersion in SBF. H00 and H35 show uniformly spread small deposits on the surfaces, whereas in H15 they seem to be grouped by zones. 


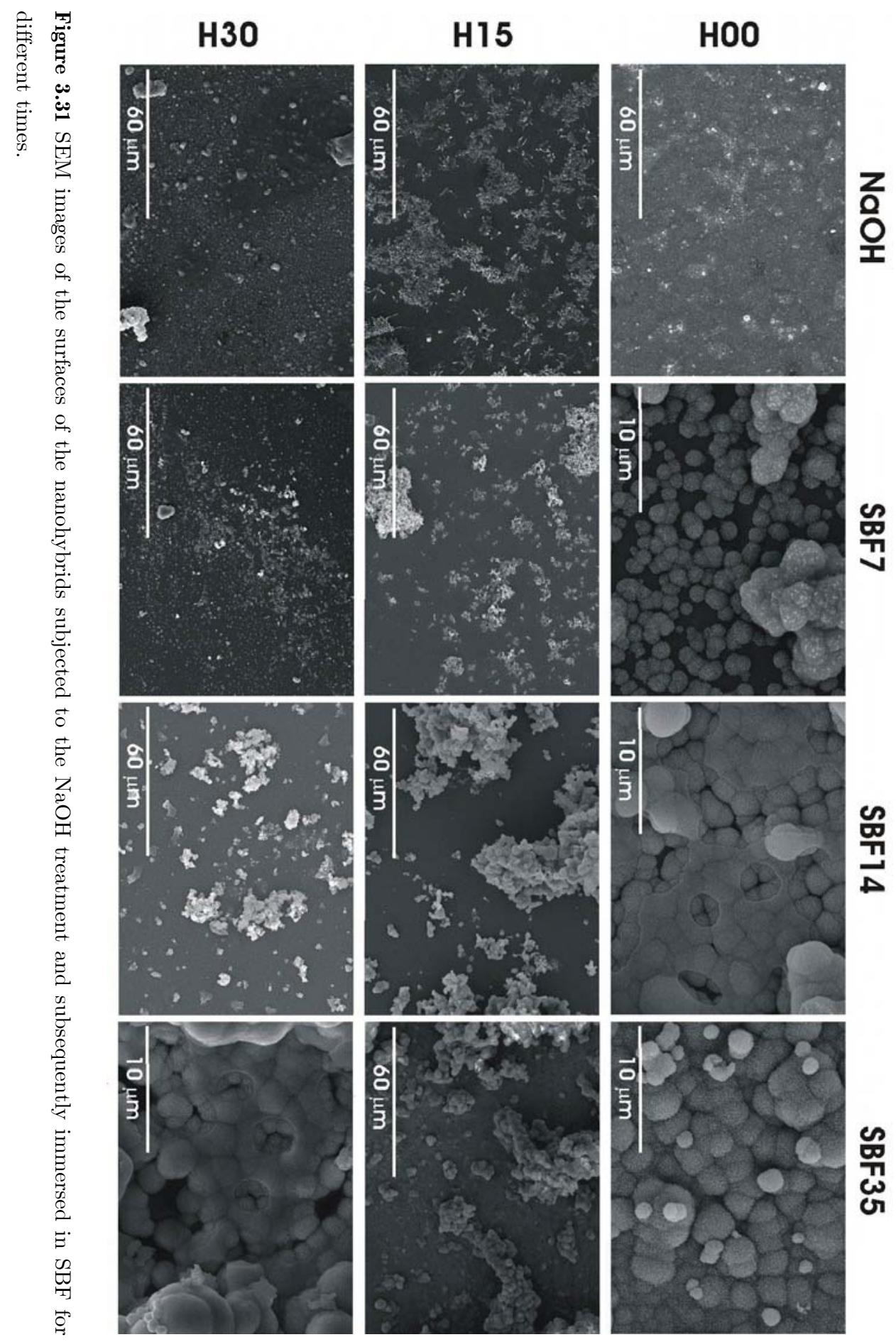




\subsubsection{Energy Dispersive Spectroscopy}

After the $\mathrm{NaOH}$ treatment, the EDS spectra show the Na peak, while the Si peak is barely detectable in nearly all the obtained hybrid profiles from the different samples. Figure 3.32 shows as an example the EDS spectrum of the H30 sample after the $\mathrm{NaOH}$ treatment, compared with the original spectrum of $\mathrm{H} 30$, which displays a very pronounced silicon peak. The $\mathrm{Na}$ and $\mathrm{Si}$ contents before and after the $\mathrm{NaOH}$ treatment are summarized in Table 3.3. Before the $\mathrm{NaOH}$ treatment, the silica contents calculated from the Si percentages at the surfaces agree well with the nominal contents, but after the $\mathrm{NaOH}$ treatment, the Si peak is absent and the $\mathrm{Na}$ peak appears. The percentage of $\mathrm{Na}$ on the surface decreases in the order: $\mathrm{H} 00>\mathrm{H} 30>\mathrm{H} 15$.
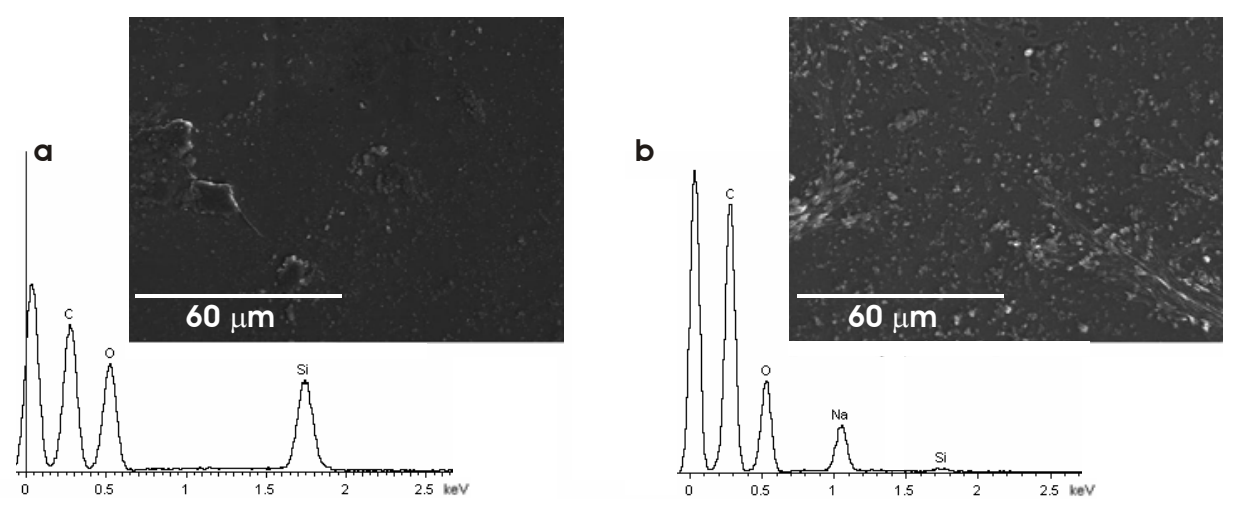

Figure 3.32 EDS spectra of H30: (a) before and (b) after the $\mathrm{NaOH}$ treatment. 
3. Results

\begin{tabular}{lccr}
\cline { 2 - 4 } & \multicolumn{3}{c}{ NaOH-treated } \\
\cline { 2 - 4 } & $\mathrm{Na}$ (at\%) $\mathbf{S i}\left(\right.$ wt\%) $\mathrm{SiO}_{2}$ & (wt\%) \\
\hline H00 & 7.82 & - & - \\
H15 & 3.94 & 0.00 & 0.00 \\
H30 & 4.74 & 0.33 & 0.71 \\
\hline
\end{tabular}

Table 3.3 EDS results of the surface of the hybrids after the $\mathrm{NaOH}$ treatment (wt\% indicates weight percentage, at\% indicates atomic percentage).

\subsubsection{Characterization of the apatite formed on the $\mathrm{NaOH}$-treated substrates}

\subsubsection{Scanning Electron Microscopy}

The SEM images of the NaOH-treated H00, H15 and H30 samples and immersed in $\mathrm{SBF}$ for the different periods are also displayed in the previous Figure 3.31. After 7 days (SBF7), H00 shows typical intricately intertwined needle-shaped crystals forming some isolated cauliflower HAp structures ${ }^{[38,53,60,94]}$, with an average diameter of about $1 \mu \mathrm{m}$. After 14 days, more cauliflowers appear on the surface, covered in some zones by continuous semitransparent coatings. With longer times of immersion, the HAp cauliflowers grow in diameter, merge to form a continuous layer, and even exhibit grape-like agglomerates of cauliflowers in successive layers leading to very irregular topographies. However, the NaOH-treated H15 and H30 show only scattered deposits within the first 14 days of immersion. At the end of the test, the H15 surface shows the same aspect as H00, whereas the H30 surface presents an aspect similar to H00 after 14 days. 


\subsubsection{Energy Dispersive Spectroscopy}

Table 3.4 summarizes the EDS results of the $\mathrm{NaOH}$-treated samples, after immersion in SBF for different times. The main elements in $\mathrm{H} 00$ are $\mathrm{Ca}$ and $\mathrm{P}$, but $\mathrm{Na}, \mathrm{Mg}, \mathrm{K}$ and $\mathrm{Cl}$ from the $\mathrm{SBF}$ also precipitate. The $\mathrm{Ca} / \mathrm{P}$ atomic ratio presents heterogeneous values. The $(\mathrm{Ca}+\mathrm{Na}+\mathrm{Mg}+\mathrm{K}) / \mathrm{P}$ is higher than the $\mathrm{Ca} / \mathrm{P}$ ratio, basically due to the precipitation of $\mathrm{NaCl}$, as reflected by the high $\mathrm{Na} / \mathrm{Ca}$ and $\mathrm{Cl} / \mathrm{P}$ ratios, the $\mathrm{Mg} / \mathrm{Ca}$ and $\mathrm{K} / \mathrm{Ca}$ ratios being low in all cases. $\mathrm{H} 15$ and $\mathrm{H} 30$ precipitate salts from the SBF at short times of immersion, basically $\mathrm{NaCl}$. At the end of the test, the $\mathrm{Ca} / \mathrm{P}$ ratios of the three samples seem to approximate to the physiological ratio (1.65) ${ }^{[54]}$ in the three cases, although the presence of $\mathrm{NaCl}$ is still quite relevant.

\begin{tabular}{lrccccc} 
& \multicolumn{7}{c}{ NaOH-treated } \\
\cline { 2 - 7 } & $\frac{C a}{P}$ & $\frac{C a+N a+M g+K}{P}$ & $\frac{N a}{C a}$ & $\frac{M g}{C a}$ & $\frac{K}{C a}$ & $\frac{C l}{P}$ \\
\cline { 2 - 7 } & \multicolumn{7}{c}{ SBF7 } \\
\hline H00 & 1.82 & 2.32 & 0.33 & 0.11 & 0.00 & 0.39 \\
H15 & - & & & & & \\
H30 & - & \multicolumn{7}{c}{ SBF14 } \\
\hline H00 & 1.37 & 2.62 & 0.70 & 0.07 & 0.07 & 1.06 \\
H15 & - & & & & & \\
H30 & - & & & & & \\
\hline & & & & & \\
\hline H00 & 1.49 & 3.86 & 1.48 & 0.07 & 0.04 & 2.70 \\
H15 & 1.65 & 2.29 & 0.30 & 0.03 & 0.00 & 0.63 \\
H30 & 1.69 & 3.22 & 0.91 & 0.00 & 0.00 & 1.54 \\
\hline
\end{tabular}

Table 3.4 $\mathrm{Ca} / \mathrm{P},(\mathrm{Ca}+\mathrm{Na}+\mathrm{Mg}+\mathrm{K}) / \mathrm{P}, \mathrm{Na} / \mathrm{Ca}, \mathrm{Mg} / \mathrm{Ca}, \mathrm{K} / \mathrm{Ca}$ and $\mathrm{Cl} / \mathrm{P}$ atomic ratios obtained from the EDS results on the $\mathrm{NaOH}$-treated hybrids after different times in SBF. 
3. Results

3.4.3 Surface structural changes of the substrates due to the CaP treatment

\subsubsection{Scanning Electron Microscopy}

After the $\mathrm{NaOH}$ and $\mathrm{CaP}$ treatments (alternative soaking in calcium ion and phosphate ion solutions) and before the immersion in SBF, the three types of samples appeared wrinkled and already coated with deposits, Figure 3.33 (column headed CaP). Figure 3.34 shows the surface of the H00 sample after the CaP treatment at higher magnification. The surface is completely coated and clusters of globular-shaped structures of approximately $100 \mathrm{~nm}$ of average diameter are deposited above. 

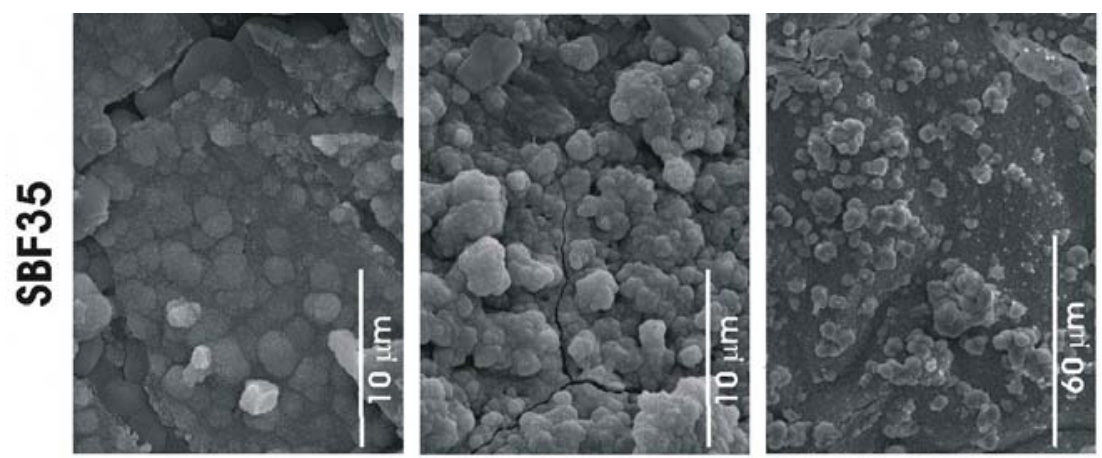

๘ั)
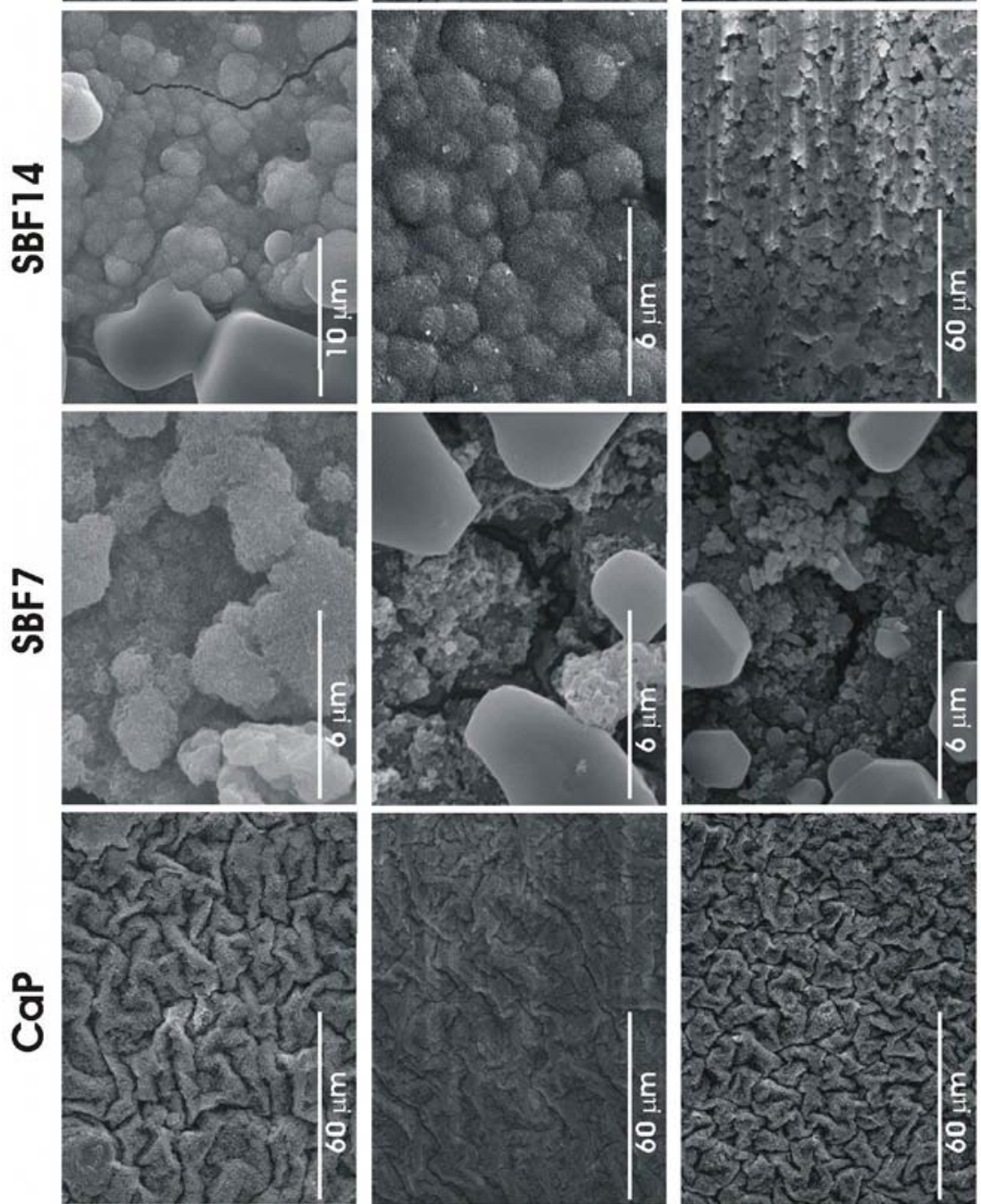

$\mathrm{OOH}$

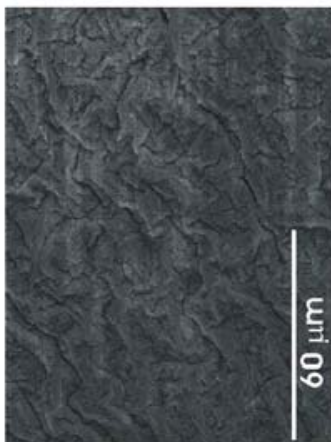

SLH

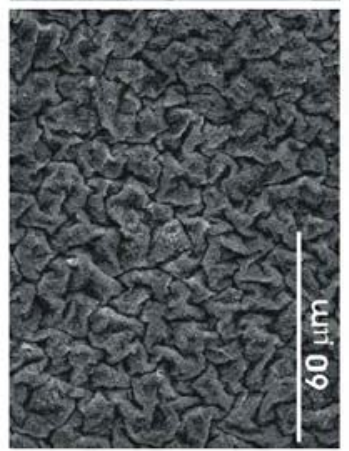

OEH 
3. Results

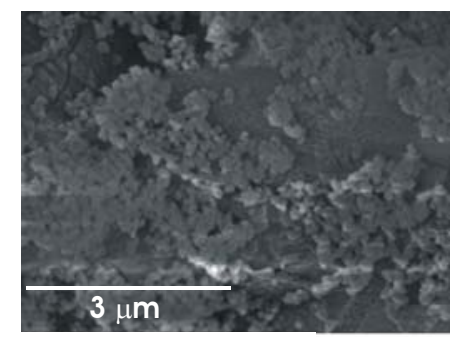

Figure 3.34 SEM image of H00 after the CaP treatment, at higher magnification than that shown in Figure 3.32.

\subsubsection{Energy Dispersive Spectroscopy}

The EDS spectra show mainly the $\mathrm{Ca}$ and $\mathrm{P}$ peaks, but also those from $\mathrm{Na}, \mathrm{K}$ and $\mathrm{Cl}$. The percentages of the different elements are listed in Table 3.5. Both $\mathrm{K}$ and $\mathrm{Cl}$ come from the salts employed in the alternate soaking treatment, while $\mathrm{Na}$ is that remaining from the previous treatment. The percentages of $\mathrm{Ca}$ and $\mathrm{P}$ on the surface decrease in the order: H00 $>$ H15 $>$ H30. Figure 3.35 shows the EDS spectra of the $\mathrm{H} 15$ sample initially and after the $\mathrm{CaP}$ treatment, as an example.

\begin{tabular}{|c|c|c|c|c|c|c|c|c|}
\hline & \multicolumn{8}{|c|}{ CaP-treated } \\
\hline & $\begin{array}{c}\mathrm{Ca} \\
(\mathrm{at} \%)\end{array}$ & $\begin{array}{c}\mathbf{P} \\
(\text { at\%) }\end{array}$ & $\mathrm{Ca} / \mathrm{P}$ & $\begin{array}{c}\mathrm{Na} \\
(\text { at\%) }\end{array}$ & $\begin{array}{c}\mathrm{Cl} \\
(\text { at\%) }\end{array}$ & $\begin{array}{c}\mathrm{K} \\
(\mathrm{at} \%)\end{array}$ & $\begin{array}{c}\mathrm{Si} \\
(\mathrm{wt} \%)\end{array}$ & $\begin{array}{c}\mathrm{SiO}_{2} \\
\text { (wt\%) }\end{array}$ \\
\hline HOO & 7.32 & 4.28 & 1.71 & 4.71 & 0.13 & 0.00 & - & - \\
\hline H15 & 6.75 & 4.59 & 1.47 & 1.66 & 0.48 & 1.18 & 0.22 & 0.47 \\
\hline H30 & 5.51 & 3.95 & 1.39 & 2.05 & 0.24 & 0.86 & 0.15 & 0.32 \\
\hline
\end{tabular}

Table 3.5 EDS results of the surface of the hybrids after the $\mathrm{NaOH}$ and $\mathrm{CaP}$ treatments (wt\% indicates weight percentage, at\% indicates atomic percentage). 

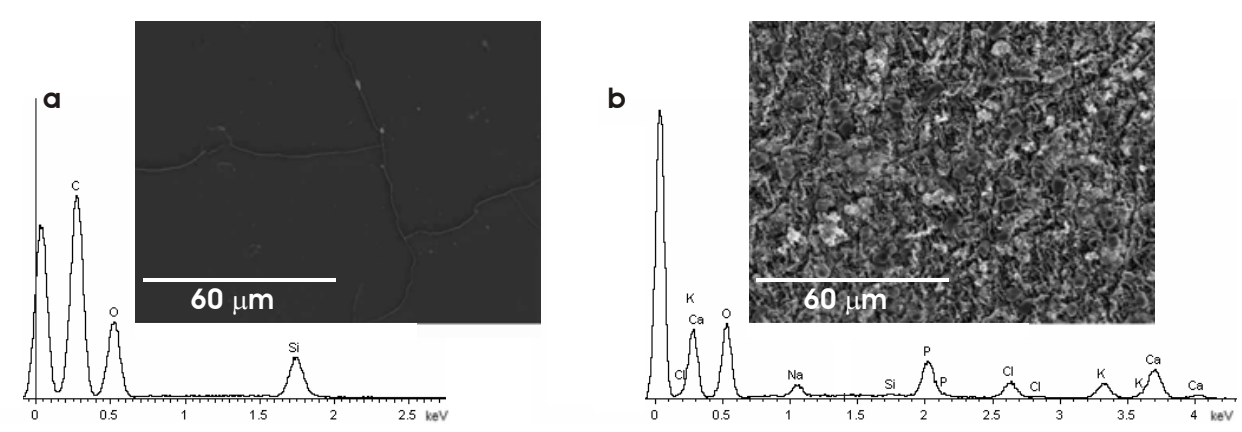

Figure 3.35 EDS spectra of H15: (a) initially and (b) after the CaP treatment.

\subsubsection{Characterization of the apatite formed on the CaP-treated substrates}

\subsubsection{Scanning Electron Microscopy}

The SEM images of the CaP-treated samples after the immersion in SBF are shown in Figure 3.33. There are not apparently differences between the three types of samples. The soaking in SBF accelerates the deposition of HAp cauliflowers in successive layers, i.e., skips the nucleation time, in combination with the deposition of salts. The bottom coatings, i.e., those deposited at short soaking times, are composed of needle-shaped nanocrystals but do not show well defined cauliflowers, nonetheless those formed in $2 \times \mathrm{SBF}$ do. All the coated surfaces are fairly cracked.

\subsubsection{Energy Dispersive Spectroscopy}

The main elements are $\mathrm{Ca}$ and $\mathrm{P}$, but $\mathrm{Na}, \mathrm{Mg}, \mathrm{K}$ and $\mathrm{Cl}$ from the $\mathrm{SBF}$ also precipitate. Figure 3.36 shows the EDS spectrum of the CaP-treated H00 sample after 14 days in SBF, as an example. All the spectra of the different samples after the HAp-coating present similar aspect. The $\mathrm{Ca} / \mathrm{P}$ atomic ratios (Table 3.6) present heterogeneous values and the $(\mathrm{Ca}+\mathrm{Na}+\mathrm{Mg}+\mathrm{K}) / \mathrm{P}$ ratios are higher, 
basically due to the precipitation of $\mathrm{NaCl}$, which is evident from the high $\mathrm{Na} / \mathrm{Ca}$ and $\mathrm{Cl} / \mathrm{P}$ ratios.
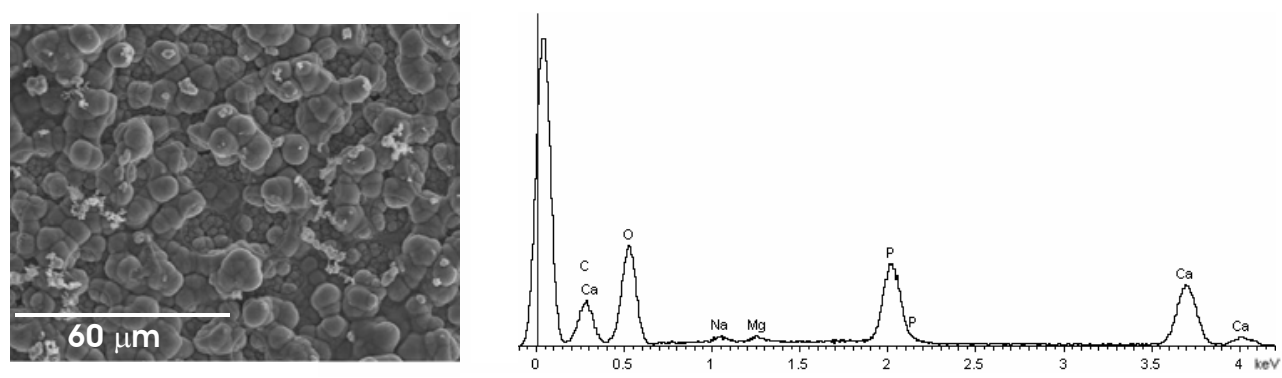

Figure 3.36 EDS spectrum of the H00 CaP-treated sample after 14 days in SBF.

\begin{tabular}{llllll}
\hline CaP-treated \\
\hline$\frac{C a}{P}$ & $\frac{C a+N a+M g+K}{P}$ & $\frac{N a}{C a}$ & $\frac{M g}{C a}$ & $\frac{K}{C a}$ & $\frac{C l}{P}$ \\
\hline
\end{tabular}

SBF7

\begin{tabular}{rrrrrrr}
\hline H00 & 1.29 & 1.85 & 0.34 & 0.06 & 0.03 & 0.36 \\
H15 & 2.00 & 4.51 & 1.08 & 0.13 & 0.03 & 1.80 \\
H30 & 4.21 & 15.97 & 2.30 & 0.27 & 0.04 & 6.19 \\
\hline \multicolumn{7}{c}{ SBF14 } \\
\hline H00 & 1.39 & 1.97 & 0.05 & 0.04 & 0.33 & 0.00 \\
H15 & 1.34 & 1.49 & 0.07 & 0.04 & 0.00 & 0.04 \\
H30 & 1.78 & 13.32 & 4.51 & 0.13 & 0.00 & 7.38 \\
\hline & & & SBF35 & & \\
\hline H00 & 1.53 & 1.94 & 0.19 & 0.04 & 0.04 & 0.32 \\
H15 & 1.52 & 2.63 & 0.68 & 0.04 & 0.06 & 1.53 \\
H30 & 2.04 & 3.14 & 0.32 & 0.08 & 0.00 & 0.18 \\
\hline
\end{tabular}

Table 3.6 $\mathrm{Ca} / \mathrm{P},(\mathrm{Ca}+\mathrm{Na}+\mathrm{Mg}+\mathrm{K}) / \mathrm{P}, \mathrm{Na} / \mathrm{Ca}, \mathrm{Mg} / \mathrm{Ca}, \mathrm{K} / \mathrm{Ca}$ and $\mathrm{Cl} / \mathrm{P}$ atomic ratios obtained from the EDS results on the CaP-treated samples after different times in SBF. 


\subsection{Bioactive $\mathrm{P}$ (EMA-co-HEA) $/ \mathrm{SiO}_{2}$ scaffolds mimicking natural dentin structure}

\subsubsection{Structure of the $\mathrm{P}(\mathrm{EMA}-\mathrm{co}-\mathrm{HEA}) / \mathrm{SiO}_{2}$ nanohybrid scaffolds}

\subsubsection{Scanning Electron Microscopy}

Figure 3.37 shows a transversal SEM image of the H15 scaffold before eliminating the fibres template. Figure 3.38 displays the micrographies of some scaffolds after the fibre dissolution. The transversal sections show in all cases a homogeneous distribution of cylindrical pores of approximately $8 \mu \mathrm{m}$ of diameter, except in the case of PHEA, where the majority of the pores collapses and the diameter of the remaining pores decreases due to the shrinkage of the scaffold.

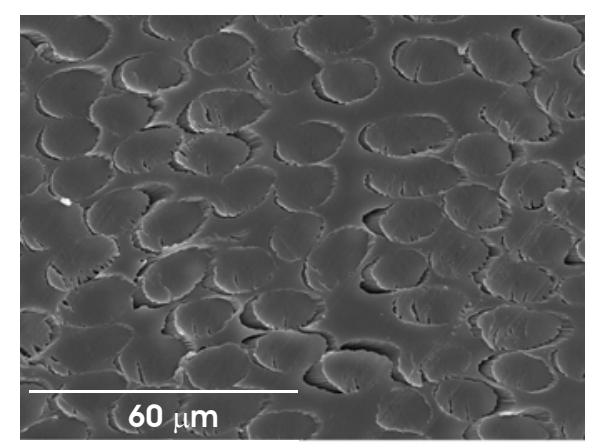

Figure 3.37 SEM image of a H15 scaffold before eliminating the fibres template. 

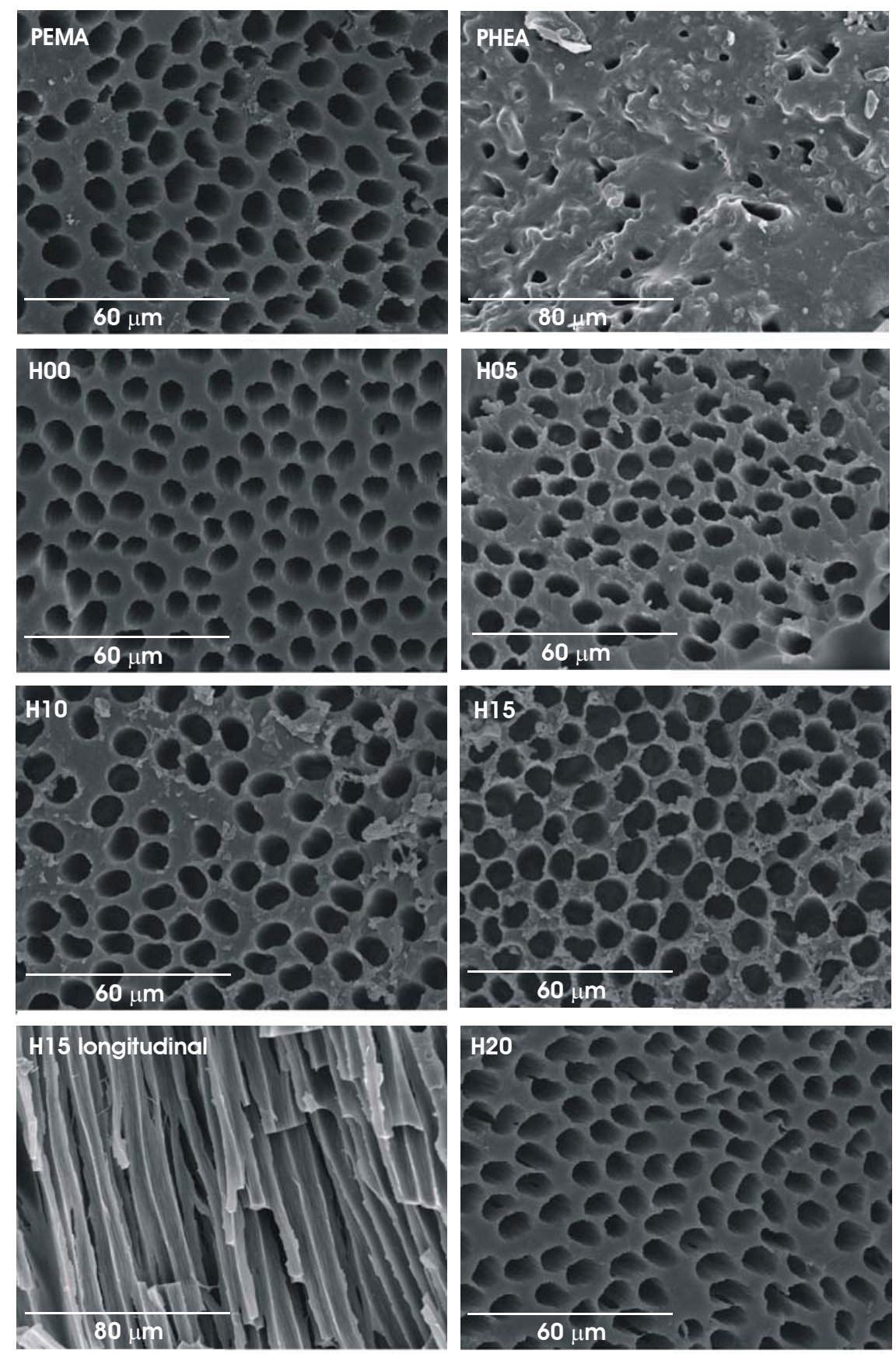

Figure 3.38 SEM images of the scaffolds in transversal section (except H15 longitudinal). 


\subsubsection{Characterization of the nanohybrid $\mathrm{P}(\mathrm{EMA}-\mathrm{co}-\mathrm{HEA}) / \mathrm{SiO}_{2}$ scaffolds}

\subsubsection{Porosity}

The porosities obtained for the homopolymers were $49.8 \%$ for PEMA and $14.5 \%$ for PHEA, and for the copolymer the porosity lies between them. The porosity of the hybrids, $\pi$, increases in the hybrids in comparison with the copolymer (Table 3.7), achieving values in the vicinity of $50 \%$, and does not seem to be influenced significantly by the different silica content.

\begin{tabular}{lc}
\hline Scaffold composition & $\boldsymbol{\pi}(\boldsymbol{\%})$ \\
\hline PEMA & $49.76 \pm 4.31$ \\
PHEA & $14.55 \pm 0.73$ \\
H00 & $37.26 \pm 3.03$ \\
H05 & $47.93 \pm 5.35$ \\
H10 & $50.96 \pm 3.18$ \\
H15 & $52.25 \pm 0.05$ \\
H20 & $53.71 \pm 6.01$ \\
\hline
\end{tabular}

Table 3.7 Porosity of the scaffolds.

\subsubsection{Compression tests}

The compressive elastic moduli of the scaffolds, $E_{\text {scff }}$, have been obtained from the slope of the stress-strain curves performed in the longitudinal direction, and are listed in Table 3.8. The values obtained for the homopolymers are $3788 \mathrm{MPa}$ for PEMA and $161 \mathrm{MPa}$ for PHEA. The elastic modulus of the H00 scaffold is very similar to that of PEMA, slightly decreases for the H05 scaffold and then increases with the amount of silica up to $6238 \mathrm{MPa}$ for the hybrid sample H20. The elastic 
moduli of the nanohybrid scaffolds are somewhat higher than those of the corresponding bulk samples (Table 3.8), especially for the H15 scaffold.

\begin{tabular}{lrc}
\hline Scaffold composition & $\begin{array}{c}\boldsymbol{E}_{\text {scff }} \\
(\mathbf{M P a})\end{array}$ & $\boldsymbol{E}_{\text {scff }} / \boldsymbol{E}_{\text {bulk }}$ \\
\hline PEMA & 3788 & 0.90 \\
PHEA & 161 & 1.13 \\
H00 & 3685 & 1.39 \\
H05 & 3342 & 1.21 \\
H10 & 5380 & 1.89 \\
H15 & 6156 & 2.15 \\
H20 & 6238 & 1.67 \\
\hline
\end{tabular}

Table 3.8 Compressive elastic moduli of the scaffolds, $E_{s c f f}$, and ratio between the compressive elastic moduli of the scaffolds and those of the corresponding bulk samples, $E_{\text {scaff }} / E_{\text {bulk }}$.

\subsubsection{Pyrolysis}

Figure 3.39 shows the SEM images of the residue of pyrolysis of the H15 scaffold with the purpose of comparing it with the original scaffold. The residue is still a scaffold and maintains the original shape but shrinks, i.e., the silica network contracts as the organic phase pyrolyzes. The original scaffold of parallel channels somewhat collapses, leaving a structure of smaller diameter pores (approximately 4 $\mu \mathrm{m})$. 

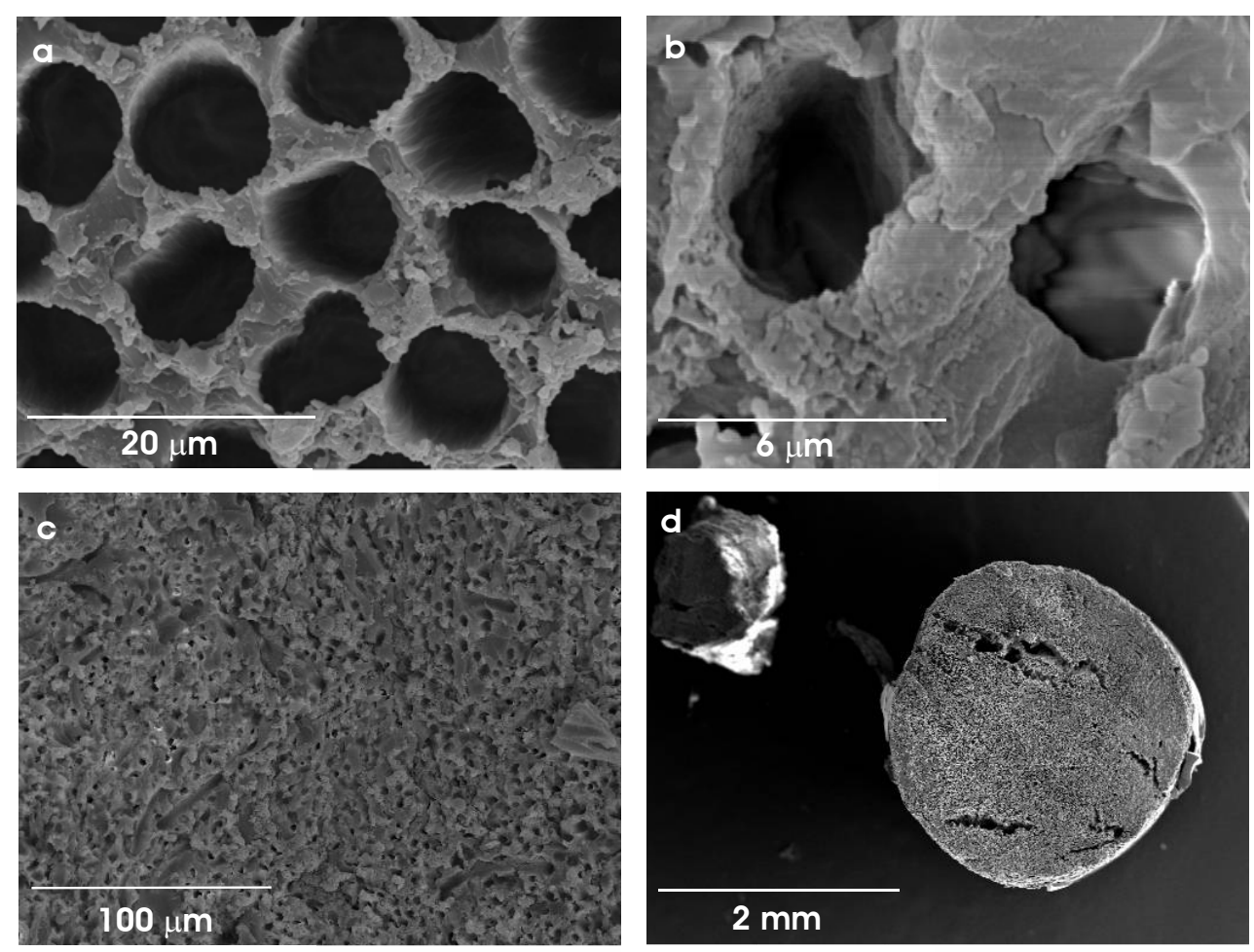

Figure 3.39 (a): H15 scaffold, (b, c): H15 scaffold, pyrolyzed at $1000^{\circ} \mathrm{C}$, (d): pyrolyzed H15 scaffold, next to the original scaffold on the right.

\subsubsection{Bioactivity of the $\mathrm{P}(\mathrm{EMA}-\mathrm{co}-\mathrm{HEA}) / 15 \mathrm{wt} \% \mathrm{SiO}_{2}$ nanohybrid scaffolds}

\subsubsection{Scanning Electron Microscopy}

Figures 3.40 and 3.41 show the SEM images of the H15 nanohybrid scaffolds, after 7 and 14 days of immersion in SBF, respectively. After 7 days in SBF, some scattered deposits are visible in the transversal section, but nothing in the interior surfaces of the pores. After 14 days, the exterior transversal surface is covered with needle-shaped crystals forming typical cauliflower HAp structures, with an average diameter of $1 \mu \mathrm{m}$, which do not clog up the pores cavities. Scattered aggregates of 


\section{Results}

cauliflowers (with larger diameter) of what seem to be subsequent layers are superposed to the first homogeneous coating. The longitudinal fracture shows that the surface of the tubular pores is almost completely coated with the first continuous apatite layer after 14 days in SBF in the regions near the transversal surfaces, but somewhat less in the inner zones.
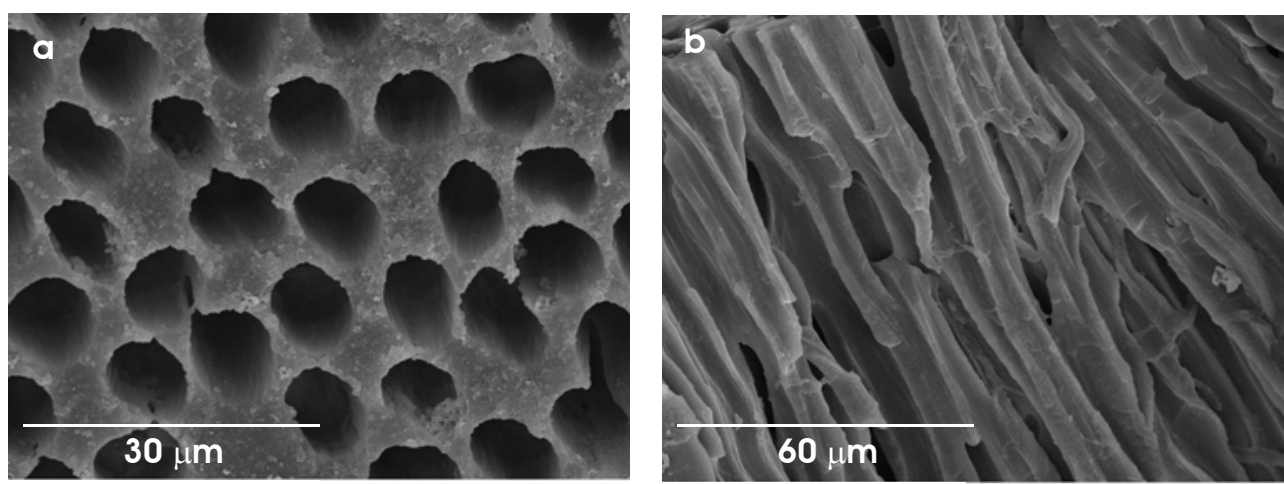

Figure 3.40 SEM images of the H15 scaffold after 7 days in SBF: (a): transversal surface and (b): longitudinal fracture. 

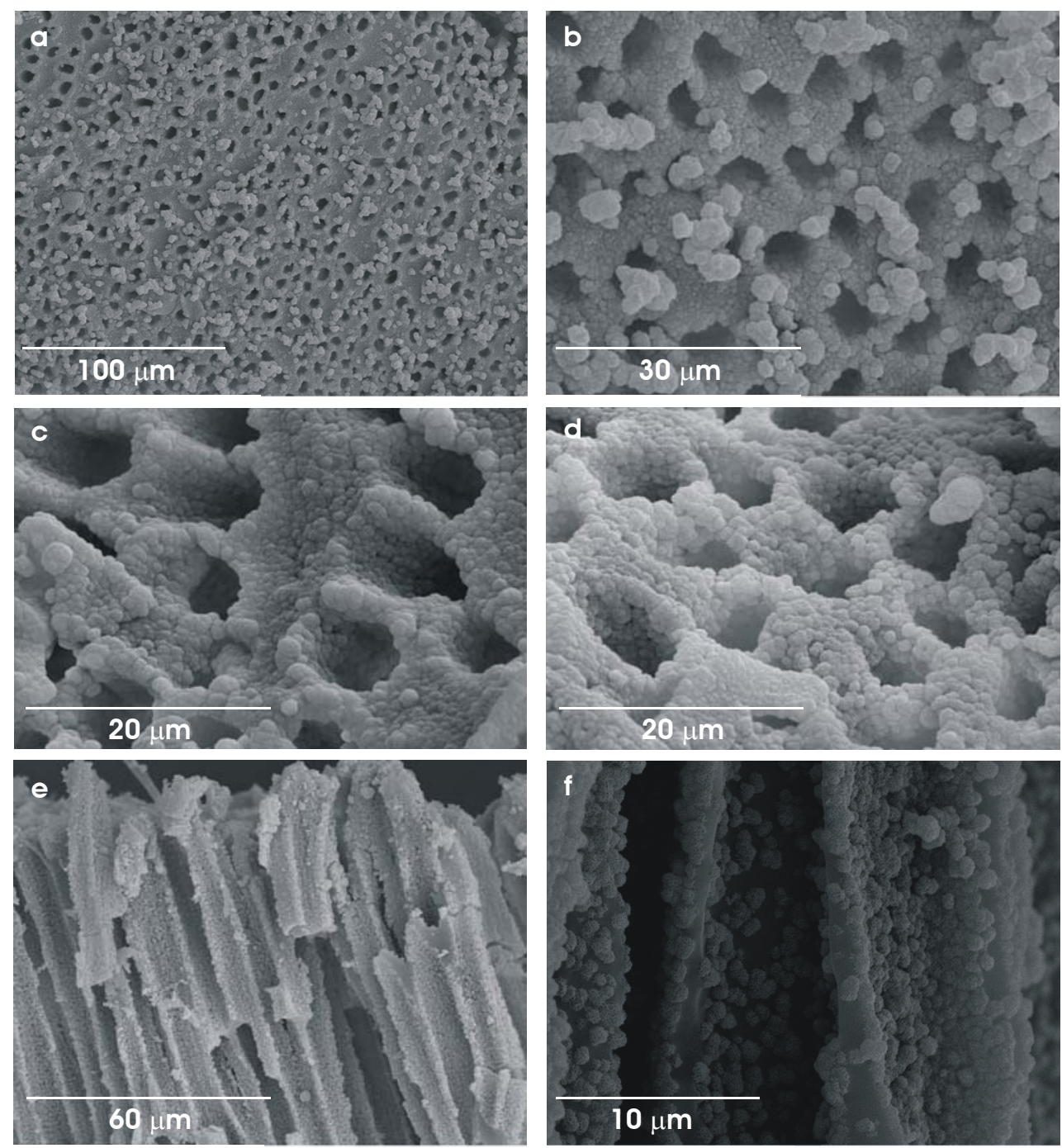

Figure 3.41 SEM images of the H15 scaffold after 14 days in SBF: (a,b,c,d): transversal surface, and (e, f): longitudinal fracture.

\subsubsection{Energy Dispersive Spectroscopy}

Figure 3.42 shows an EDS spectrum of the transversal surface of the H15 scaffold after 14 days in SBF. An average $\mathrm{Ca} / \mathrm{P}$ ratio of 1.56 was obtained, which is slightly 


\section{Results}

lower than the physiological $\mathrm{HAp} \mathrm{Ca} / \mathrm{P}$ ratio. Other elements like $\mathrm{Na}$ and $\mathrm{Cl}$ were also detected.

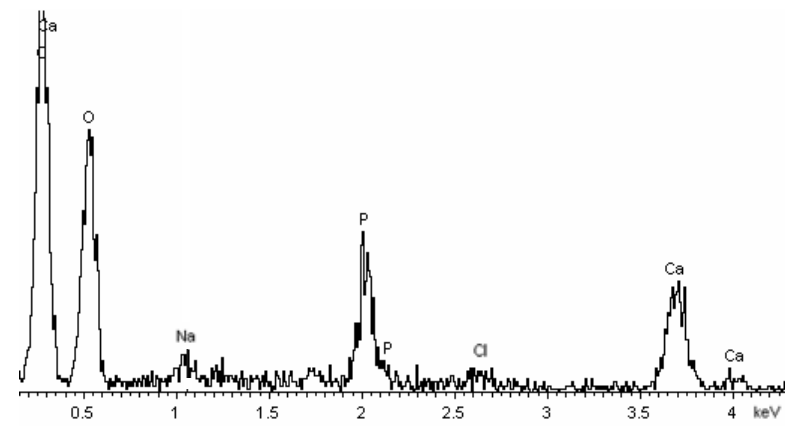

Figure 3.42 EDS spectrum of the H15 scaffold after 14 days in SBF.

\subsubsection{Compression test}

The compressive elastic modulus of the H15 scaffold after 14 days in SBF was 8192 MPa, 1.33-fold that of the original H15 scaffold. 


\section{Chapter 4}

\section{Discussion}

\subsection{On the structure of $\mathrm{SiO}_{2}$ in the $\mathrm{P}(\mathrm{EMA}-$ co-HEA) polymeric matrix}

Hybrid nanocomposites of poly(ethyl methacrylate-co-hydroxyethyl acrylate) 70/30 wt\%/silica, $\mathrm{P}$ (EMA-co-HEA) $/ \mathrm{SiO}_{2}$, with varying proportions of silica up to 30 wt\%, were obtained in the form of sheets of approximately $0.8 \mathrm{~mm}$ of thickness by the copolymerization of the organic monomers during the simultaneous acidcatalyzed sol-gel polymerization of tetraethoxysilane. Silica contents above $30 \mathrm{wt} \%$ led to too viscous mixtures hardly injectable in moulds. Due to the presence of the $\mathrm{OH}$ group of HEA, the organic monomers solution was a good co-solvent for TEOS and water, and no additional solvent was required. The samples were optically transparent and increasingly rigid as the percentage of silica increased. The transparency of the nanocomposites is due to the fact that the characteristic morphology size remains below $400 \mathrm{~nm}$, which in turn is attributed to the use of an acid catalyst for the in situ sol-gel synthesis of the silica phase ${ }^{[0,91]}$. As stated previously, under these conditions the condensation rate is much greater than the production of silanols by the hydrolysis reaction, and the silica forms as a weakly crosslinked or ramified silicate network ${ }^{[70,91,124,129,159]}$. The hydrolysis of acrylate esters at acid $\mathrm{pH}$ is quite slow ${ }^{[113]}$. The water/TEOS molar ratio employed was below the stoichiometry of the hydrolysis reaction ( 2 instead of 4 ), which hinders the shrinkage due to the sol-gel polymerization of TEOS ${ }^{[91]}$. It is, though, sufficient, since it is also a by-product of the condensation. 


\section{Discussion}

In principle, the relative rates of polymerization of the organic and inorganic phases could induce phase separation, but when the silica network forms faster than the copolymer one, the size of the typical phase aggregate is so small that transparent materials are obtained. On the contrary, Jackson et al. ${ }^{[13]}$ observed phase separation when the free radical polymerization of the acrylate groups was fast with respect to the sol-gel reaction. Rodríguez et al. ${ }^{[149]}$ also observed a highly efficient filling of the silica pores by the organic polymer matrix' chains in PHEA $/ \mathrm{SiO}_{2}$ nanocomposites obtained by a similar procedure, and related it with the silica polymerization occurring faster than the organic polymerization. The $\mathrm{OH}$ groups of HEA play the role of co-solvents like ethanol, which make the hydrolysis reaction faster for TEOS ${ }^{[133]}$.

The monomers polymerize randomly, giving rise to an organic network that fills up the pores left by the silica structure. Thus, the obtained nanohybrids must consist in two phases, both of them in the form of networks, the silica phase being finely interdispersed or interpenetrated in the organic phase. As explained previously, the porous structure of silica in the nanohybrids is bimodal: a family of small pores in the few-nanometer range (around $3 \mathrm{~nm}$ ) within the elementary silica particles (nanodomains) produced by the liquids acting as a template during the sol-gel reaction ${ }^{[124,129]}$ and another family of pores consisting in the larger spaces (tens of nanometers) left between the aggregates of those smaller elementary particles ${ }^{[1,128]}$. These pores are occupied by the copolymer network (Fig. 1.6, p. 26).

The infrared spectra of the hybrids, after substracting the overlapped spectrum of the copolymer (Fig. 3.3, p. 47), reveal the increasing presence of silica at the surfaces as the $\mathrm{SiO}_{2}$ content in them increases. The absence of the broad band characteristic of the $\mathrm{OH}$ groups of the silanols or the $\mathrm{OH}$ vibrations of HEA can be explained on the basis of the rigidity of the dry samples and consequent imperfect contact with the apparatus window. In agreement with the FTIR results, chemical analysis by EDS (Fig. 3.4, p. 48) corroborates that silicon appears at the surface of the nanocomposites, and in similar quantity as in the interior. This is of great significance since silica is expected to confer bioactivity to these materials. The good agreement of the increasing percentages of thermo-decomposition residues 
(Fig. 3.7, p. 51), as well as the silica contents obtained by EDS, with the nominal inorganic contents, implies that the TEOS was efficiently hydrolyzed and condensed to silica during the sol-gel process in all cases, and presents a homogeneous distribution in the polymeric matrix. Besides, these results discard a significant dissolution of silica from the surface occurring during the water/ethanol rinse of the samples.

The fact that the $E W C^{\prime}$ 'values of the hybrids are almost constant for the different silica contents (Fig. 3.10a, p. 54), indicates that the water sorption ability of the hybrids is due essentially to their HEA component, and that this unit is as hydrophilic in the nanocomposites as it is in the copolymer, i.e., it is not more constrained by the increasing presence of silica. Heterocondensation reactions between silica and the organic copolymer, if existent at all, must involve a negligible number of HEA units.

Pyrolysis changes the structure of the silica network by sintering it to a glass. High magnification of the residues from pyrolysis (Fig. 3.8, p. 52) show structures of aggregated nanoparticles. The fact that pyrolized hybrids with silica contents of 15 wt\% and above retain the shape and leave a continuous structure evidences the high connectivity of the silica phase above $15 \mathrm{wt} \%$. There is quite evidence from the TEM images of the nanohybrids (Fig. 3.9, p. 53) with low silica contents up to $10 \mathrm{wt} \%$ that the inorganic phase is uniformly dispersed in the form of nanoparticles or nanodomains (their average dimension is about $10 \mathrm{~nm}$ ), which tend to aggregate in dark larger regions (silica is also detectable in the lighter areas, though). Higher silica contents produce co-continuous interpenetrated structures, where individual silica aggregates are no longer seen. In H30, silica seems to have polymerized to a more perfect interpenetrated network, since discrete inorganic domains are no longer detectable by TEM.

The $E W C$ of the copolymer (Fig. 3.10a, p. 54) resembles more that of PEMA than that of PHEA and is lower than predicted. The discrepancy of the true $E W C$ from this predicted value can be explained by the fact that the copolymer network is 


\section{Discussion}

much more rigid (has a higher $\mathrm{T}_{\mathrm{g}}$ ) than the rubbery PHEA network at ambient temperature, and thus it cannot expand as much as does the PHEA while it absorbs water, thus giving rise to this strongly nonlinear swelling. Besides, even though the copolymer swells well in a water/ethanol mixture, its $E W E C$ is lower than predicted and more similar to that of PEMA (Fig. 3.10b, p. 54), confirming that it is a random copolymer. The abnormally high $E W C$ or equilibrium SBF content values of $\mathrm{H} 30$ are not reliable and can be due to the fact that it is the most rigid hybrid and presents a rough surface, where some water could be located and falsify the results.

The theoretical equilibrium water/ethanol content obviously decreases slightly and linearly when increasing the inorganic phase. The $E W E C$ values of the hybrids are well above the theoretical ones, and those of $E W E C^{\prime}$ follow a similar tendency. The increasing relative amount of hydrophilic non-condensed Si-OH terminal groups on the surface of silica disconnected nanodomains, conjointly with the organic network expansion still not hindered by a rigid silica skeleton could account for the initial steep increase in the $E W E C$ '. Between 5 and $10 \mathrm{wt} \%$ of silica, a maximum in the $E W E C^{\prime}$ is reached, and the posterior decrease infers that a continuous silica network interpenetrated with the copolymer network has developed, which is in agreement with the continuity of the residues from pyrolysis. The formed rigid silica skeleton hinders the swelling of the organic chains, which are increasingly constrained. Besides, the interpenetrated silica network renders less silanol terminal groups available for swelling. Finally, in the H30 hybrid, the silica network formed is more perfect and thereby the polymeric matrix swells less than predicted and similarly to PEMA. 


\subsection{Characterization of $\mathrm{P}(\mathrm{EMA}-\mathrm{co}-\mathrm{HEA}) / \mathrm{SiO}_{2}$ nanocomposites}

The weight loss of the hybrids during thermal decomposition (Fig. 3.6, p. 50) accounts for the copolymer degradation and the loss of silica bonded groups such as $-\mathrm{OH}$ or remaining non-hydrolyzed $-\mathrm{OCH}_{2} \mathrm{CH}_{3}$ groups, and it occurs in several stages. Silica reduces the thermal stability of the nanocomposites, thus shifting the thermogravimetric curves to lower temperatures, but not reaching the PEMA decomposition profile, which starts to decompose at $210^{\circ} \mathrm{C}$. This loss of thermal stability of the silica hybrids was also observed by Costa et al. ${ }^{[109]}$ in PHEMA/ $\mathrm{SiO}_{2}$ composites, who explained it on the basis of a decrease in hydrogen-bonding among copolymer chains promoted by the presence of silica. Other authors ${ }^{[89,111]}$ observed the opposite effect and attributed it to a good homogeneity due to nanoscale mixing and to relatively strong heterogeneous hydrogen bonds tethering silica and polymer chains. On the one hand, the fact that the decomposition profile only seems to be affected by silica contents below $15 \mathrm{wt} \%$, and on the other hand that it is the first weight loss stage which increases in importance, suggest that high temperatures during the measurements allow condensations between non-condensed silanol groups to start again. Water produced in these condensations could be involved in the accelerated scissions of lateral chains in the organic copolymer during the thermogravimetric assays. This is in agreement with the slight aging phenomenon observed by DMS at temperatures higher than $150^{\circ} \mathrm{C}$ (insert in Fig. 3.12 , p. 58), i.e., the additional increase in the storage modulus (over that predicted by the rubber elasticity theory). Probably this happens because molecular motions at these supra- $\mathrm{T}_{\mathrm{g}}$ temperatures allow uncompleted sol-gel reactions to start again, leading to an increased connectivity of the silica network. Such an effect has been previously reported ${ }^{[91]}$. At temperatures below the glass transition, the vitrified polymeric phase hinders sol-gel reactions, which remain frozen. 


\section{Discussion}

The specific volume of the nanohybrids (Fig. 3.14, p. 59) is slightly higher than that obtained considering a highly efficient filling of the silica network pores. The linear decrease of the specific volume of the nanohybrids from $0.85 \mathrm{~cm}^{3} \mathrm{~g}^{-1}$ for $\mathrm{H} 00$ to $0.75 \mathrm{~cm}^{3} \mathrm{~g}^{-1}$ for $\mathrm{H} 30$ leads to a specific volume extrapolated for a sol-gel $100 \mathrm{wt} \%$ $\mathrm{SiO}_{2}$ of $0.53 \mathrm{~cm}^{3} \mathrm{~g}^{-1}$, which is between the higher values obtained elsewhere for acidcatalyzed silica gels using higher water/TEOS ratios $\left(0.61-0.76 \mathrm{~cm}^{3} \mathrm{~g}^{-1}\right.$ for water/TEOS ratios ranging from 4.2 to 15.3 ), and the lower value $0.45 \mathrm{~cm}^{3} \mathrm{~g}^{-1}$ of the pure silica glass obtained by curing at $900^{\circ} \mathrm{C}{ }^{[70]}$.

The results from contact angle measurements (Table 3.1, p. 60) are in accordance with the hypothesis given in the previous section about the dependence of the relative number of non-condensed silanol groups on the mass fraction of silica in the nanohybrids. The low percentage of silica explains the average water contact angle of the H05 surface being similar to that of the copolymer. An increase in surface wettability is observed on the surfaces as a consequence of the increase of the silica content and thus the increase in the number of silanol terminal polar groups at the surfaces. Regardless its higher silica content, the H30 surface seems to behave again as the copolymer surface. The dense more perfect silica network packages the copolymer chains and renders less free silanol groups available on the surface. The obtained surface tension for PEMA and its dispersive and polar components here obtained agree well with those found in the literature ${ }^{[144]}$, and with those obtained by Pérez et al. ${ }^{[137]}$ in previously swollen PEMA. This is to be expected given the low water sorption of PEMA. The high water contact angle on dry PHEA is due to the fact that hydroxyls are not exposed at the surface. However, the corresponding infrared band is detectable because PHEA is flattened in the device, contrary to what happens with the rest of the dry samples because of their rigidity. The dispersion forces and polar interactions of swollen PHEA are twice those found herein for dry PHEA, owing to its swelling ability. The polarity of the copolymer is strangely slightly lower than that of PEMA, and increases with the silica content up to a value close to PHEA for H20, due to the increasingly hydrophilic character of the surfaces of the nanohybrids. This confirms that the influence of silica is also superficial. This is of great importance since the hydrophilic character of the surfaces plays an important role during apatite 
formation ${ }^{[50,60,102,105]}$. The presence of Si-OH groups on the surface (and/or their formation by dissolution of the silica network) is related with the ability to nucleate bone-like hydroxyapatite crystals in contact with body fluids. As stated above, the steep decrease in polarity of H30 could be explained on the basis of a perfect co-continuous silica network interpenetrated with the polymeric matrix, with an insignificant amount of hydroxyl groups available at the surface, though the influence of other physical parameters such as the stiffness or the roughness of the surface cannot be excluded.

The calorimetric curve of the copolymer (Fig. 3.15, p. 62), with the glass transition lying between those of the homopolymers, suggests the absence of organic phase separation. The dynamic-mechanical spectra of the copolymer (Fig. 3.11, p. 56) shows the single main relaxation process associated to the glass transition as a sharp single drop of the storage modulus with the corresponding maximum of the loss tangent, located between the curves corresponding to both homopolymers. The rubbery plateau modulus of PHEA takes a value similar to PEMA, probably due to transestererification reactions taking place in its lateral chains. The dynamicmechanical relaxation process associated to the glass transition is more sensitive to phase heterogeneity than the glass transition detected by calorimetry ${ }^{[152]}$, and thus confirms the homogeneity of the random copolymer and the inexistence of phase separation. Fox equation does not give a good approximation for the $T_{g}$ of the copolymer even that it is a homogeneous mixture; maybe more complicated models would give more accurate results. The general increase in $T_{g}$ and the gradual shift to high temperatures of its associated mechanical relaxation (Fig. 3.12, p. 58) with increasing silica contents has been observed previously by other authors ${ }^{[109]}$, and points to the restriction of polymer chains mobility as they become more intertwined with the rigid silica network, resulting in a reinforcing effect. The compressive elastic modulus of the nanocomposites (Fig. 3.17, p. 64) calculated from mechanical compression tests increases from 15 to $30 \mathrm{wt} \%$ of silica, up to a value for $\mathrm{H} 30$ close to that of PEMA, owing to this silica reinforcing effect. The elastic moduli of the nanohybrids are expected to increase even more in contact with biological fluids, due to hydroxyapatite coating, up to values closer to that of the elastic human dentin modulus, $14.47 \mathrm{GPa}{ }^{[151]}$. 


\section{Discussion}

At first sight, the decrease in $\Delta c_{p}$ (Fig. 3.16b, p. 62) seems to suggest that as the amount of silica in the sample increases, the number of polymer chains able to participate in the glass transition process decreases. However, the fraction of copolymer able to undergo conformational motions at the glass transition is always close to unity, which indicates that all the copolymer chains existent in the hybrids are able to participate in the glass transition process. Nonetheless, the silica network hinders the polymer chain motions, broadening the glass transition process. The vanishing of the calorimetric glass transition with the increase in silica content has already been observed by other authors ${ }^{[11,154]}$. They attributed the absence of clear calorimetric glass transition to the confinement of polymer chains in domains smaller than $15 \mathrm{~nm}$, from which the characteristic long distance motions of the glass-transition phenomenon are restricted. This is in agreement with a very fine and interpenetrated polymer/silica morphology. In parallel, the main mechanical relaxation broadens, decreases in intensity and shifts to higher temperatures. The rubbery modulus increases, mainly from 10 wt\% of silica content. This strong increase of the rubbery plateau modulus agrees well with the literature ${ }^{[91,111,117,131,148]}$ and seems to be related with the percolation of the silica phase, forming a continuous network extended throughout the sample for silica contents higher than that threshold, which constrains the long distance cooperative motions of the copolymer chains. The fact that only for these silica contents a continuous densified silica structure was obtained after performing a pyrolysis and removal of the organic phase, is consistent with this observation. Other authors ${ }^{[89]}$ attributed the increase of the rubbery plateau modulus to the polymer chains extending into the nanoscale silica network with relatively strong hybrid hydrogen bondings. In this case, this explanation would be difficult to reconcile with the impoverished thermal stability of the hybrids already discussed. Nevertheless, despite the increase in the rubbery modulus with the increase of silica acting as reinforcing agent, the mechanical relaxation of the copolymer does not disappear after a $20 \mathrm{wt} \%$ of silica. In agreement with other authors ${ }^{[91,154]}$, this shows that although the glass transition is hardly noticeable in calorimetric measurements, it has not disappeared from the hybrids, because it is still detected by dynamicmechanical analysis through its associated main relaxation. 


\title{
4.3 Bioactivity of $\mathrm{P}(\mathrm{EMA}-\mathrm{co}-\mathrm{HEA}) / \mathrm{SiO}_{2}$ nanocomposites
}

\author{
4.3.1 On the morphology and composition of the apatite formed on the \\ substrates in SBF
}

The homopolymers PEMA and PHEA did not induce an efficient apatite growth during the in vitro test in SBF, while the copolymer did (Fig. 3.19, p. 66-67). The PEMA surface induced the deposition of some apatite formations very slowly and precipitated salts from the SBF simultaneously. The PHEA homopolymer did not nucleate apatite practically. The copolymer induced the nucleation and growth of apatite, more slowly than the hybrids with 5-20 wt\% silica, but faster than H30. This suggests that both polar carboxyl and hydroxyl groups are effective apatite nucleators, but textural and physical properties such as swelling and polarity and mechanical modulus of the surfaces are also relevant.

The H15 hybrid required 5 days to induce apatite nucleation (Fig. 3.22, p. 70), whereas H30 needed a longer incubation period, even longer than that of the copolymer. After 7 days, the surfaces of H05, H10, H15 and H20 were completely covered of a uniform apatite layer, and even promoted the precipitation of aggregates of apatite or plain structures on it. This indicates that the rate of formation of the apatite layer on these hybrids depends on the induction time, but once the apatite nuclei are formed, they grow rapidly. The first apatite layer is composed of porous cauliflowers of nanocrystals with needle-like morphology similar to the apatite structures found in physiological bone. This needle-like morphology can be explained on the basis of the HAp lattice parameters $(\mathrm{a}=0.94$ $\mathrm{nm}$ and $\mathrm{c}=0.69 \mathrm{~nm}$ ) and its symmetry (hexagonal, S.G. $\mathrm{P} 6_{3} / \mathrm{m}$ ) ${ }^{[5]}$, which promote a preferred oriented growth along the c-axis. Once apatite has nucleated in a certain location, it grows outwards in a radial pattern ${ }^{[58]}$, leading to cauliflower or hemispherical structures that reach maximum average sizes of $1 \mu \mathrm{m}$ before they merge to form a continuous layer. In the copolymer, the apatite layer did not 


\section{Discussion}

attain a complete coverage of the surface within 7 days. The H30 hybrids displayed scattered HAp cauliflowers of small diameters.

The body fluid is already supersaturated with respect to the apatite under normal conditions. Once the apatite nuclei are formed, they can grow spontaneously by consuming the calcium and phosphate ions from the surrounding body fluid. The $2 \times \mathrm{SBF}$ solution, having ion concentrations twice as large as those of SBF, increases the degree of supersaturation to apatite while maintaining the $\mathrm{Ca} / \mathrm{P}$ atomic ratio. In such a solution apatite can grow more rapidly.

With the increase of the SBF concentration, new apatite layers grew on the hybrids on the preformed cohesive one with the same needle-like structure, and the cauliflowers got larger as more apatite was incorporated. This indicates that apatite molecules of the first layer provided secondary nucleation sites for additional apatite formation, which interconnected successive layers ${ }^{[42]}$. In this stage, the amount of nucleating sites at the surface seemed to decrease, and accordingly some spherical formations of needle-like polycrystals grew perpendicularly to the surface leading to the formation of clusters or grape-like structures. The topography of the surfaces was in some cases quite irregular and sparkles difficulted taking good images. At the end of the in vitro test in SBF, the surfaces of the hybrids and the copolymer were apparently equivalent, and the apatite that deposited at the top displayed the same needle-like structure of the cauliflowers below.

From the EDS (Table 3.2, p. 72) and FTIR results (Fig. 3.24, p. 74), the composition of the apatite coatings of the copolymer and the hybrids could be inferred. The EDS results indicate that the precipitated layers consist basically in $\mathrm{Ca}$ and $\mathrm{P}$, although other elements from the $\mathrm{SBF}(\mathrm{Na}, \mathrm{Mg}, \mathrm{K}$ and $\mathrm{Cl}$ ) are also present. The chemical composition of biological apatite is not fixed due to the different elements available in the body. Among the substituting ions in bone and tooth mineral are $\mathrm{Na}^{+}, \mathrm{K}^{+}, \mathrm{Fe}^{2+}, \mathrm{Mg}^{2+}, \mathrm{F}^{-}$and $\mathrm{Cl}^{-}$, and also complex ions such as $\mathrm{CO}_{3}{ }^{2-}$ and $\mathrm{HPO}_{4}{ }^{2-}$. The $\mathrm{Mg} / \mathrm{Ca}$, and $\mathrm{Na} / \mathrm{Ca}$ atomic ratios of the bone apatite are 0.016 , and 0.022 , respectively ${ }^{[54]}$. 
Despite the existence of HAp (or calcium phosphate, although not strictly correct, these two terms are indistinctly used in the biomaterials literature) after 7 days in SBF demonstrated by EDS, FTIR is not able to reveal the apatite peaks until 14 days of immersion. The FTIR peaks ascribed to $\mathrm{CO}_{3}{ }^{2-}$ confirm that the apatite formed on the substrates is a carbonate ion-containing HAp. As stated previously, when the HAp is deposited from the $\mathrm{SBF}$, there is less substitution of $\mathrm{PO}_{4}{ }^{3-}$ by $\mathrm{CO}_{3}{ }^{2-}$ in the apatite lattice because the concentration of $\mathrm{HCO}_{3}{ }^{-}$in the SBF is lower than that in the blood plasma, and consequently the $\mathrm{Ca} / \mathrm{P}$ ratio is lower. The incorporation of $\mathrm{HPO}_{4}{ }^{2-}$ groups to the apatite cannot be excluded since its FTIR characteristic absorption band at $868 \mathrm{~cm}^{-1}$ could be obscured by the $\mathrm{CO}_{3}{ }^{2-}$ band The concentration of $\mathrm{HPO}_{4}{ }^{2-}$ ions increases notably with increasing IP ${ }^{[54]}$, so its presence in the apatite coatings seems to be quite reasonable.

The deficit in negative charge caused by the partial substitution of $\mathrm{PO}_{4}{ }^{3-}$ by either $\mathrm{CO}_{3}{ }^{2-}$ or $\mathrm{HPO}_{4}{ }^{2-}$ in the biological apatite can be compensated by a second substitution by an ion with dissimilar charge or by the loss of positive charge, as through removal of $\mathrm{Ca}^{2+}$ from the lattice (Ca-deficient apatites) ${ }^{[5,54]}$. Physiological $\mathrm{HAp}$ is almost always calcium-deficient. The presence of $\mathrm{HPO}_{4}{ }^{2-}$ ions decreases the $\mathrm{Ca} / \mathrm{P}$ ratio below the stoichiometric value, and the presence of $\mathrm{CO}_{3}{ }^{2-}$ increases this ratio above the theoretical one. When $\mathrm{HPO}_{4}{ }^{2-}$ ions are present, the HAp takes the form $\mathrm{Ca}_{10-\mathrm{x}}\left[\left(\mathrm{PO}_{4}\right)_{6-2 \mathrm{x}}\left(\mathrm{HPO}_{4}\right)_{2 \mathrm{x}}\right](\mathrm{OH})_{2}$ with $0<\mathrm{x} \leq 1$, which results in a half $\mathrm{Ca}$ deficiency, to give a $\mathrm{Ca} / \mathrm{P}$ ratio below 1.67. One substitution of $\mathrm{CO}_{3}{ }^{2-}$ for $\mathrm{PO}_{4}{ }^{3-}$ $\left(\mathrm{Ca}_{10-\mathrm{x}}\left[\left(\mathrm{PO}_{4}\right)_{6-2 \mathrm{x}}\left(\mathrm{CO}_{3}\right)_{2 \mathrm{x}}\right](\mathrm{OH})_{2}\right)$ results in one $\mathrm{P}$ and a half $\mathrm{Ca}$ deficiencies, to give a $\mathrm{Ca} / \mathrm{P}$ ratio larger than 1.67 .

The absence of the $\mathrm{OH}$ characteristic band in the FTIR spectra does not necessarily imply that the apatite formed lacks of $\mathrm{OH}$ groups, and can be attributed to the rigidity of the dry samples and imperfect contact with the device, because the $\mathrm{OH}$ vibration band from the HEA or the silanol terminal groups were not detected in the nanocomposites, either. Besides, as stated in the literature ${ }^{[5,52,56,67]}$, the lack of $\mathrm{OH}^{-}$could also be partly attributed to the demands of charge 


\section{Discussion}

balance created by the replacement of $\mathrm{PO}_{4}^{3-}$ groups by others $\left(\mathrm{Ca}_{10-\mathrm{x}}\left[\left(\mathrm{PO}_{4}\right)_{6-}\right.\right.$ $\left.\left.{ }_{\mathrm{x}}\left(\mathrm{HPO}_{4}\right)_{\mathrm{x}}\right](\mathrm{OH})_{2-\mathrm{x}}, \mathrm{Ca}_{10-\mathrm{x}}\left[\left(\mathrm{PO}_{4}\right)_{6-\mathrm{x}}\left(\mathrm{CO}_{3}\right)_{\mathrm{x}}\right](\mathrm{OH})_{2-\mathrm{x}}\right)$. Indeed, bone apatite does not seem to have a high concentration of $\mathrm{OH}^{-}$groups, if it contains any $\mathrm{OH}^{-}$groups at all. There is growing evidence for the lack of $\mathrm{OH}^{-}$in bone apatite, based on results from Raman and infrared spectroscopy, inelastic neutron scattering and nuclear magnetic resonance spectroscopy ${ }^{[5]}$. Neither the exact nature of the carbonate substitution nor the state of hydroxylation of the lattice are well understood to date. Even though, the mineral in bone is usually referred to as hydroxyapatite.

The $\mathrm{Ca} / \mathrm{P}$ ratios do not seem to be influenced by the silica content of the underlying substrate. They are initially lower than the stoichiometric or the physiological HAp ratio at short soaking times, but in the range of amorphous calcium phosphate $\left(\mathrm{ACP}, \mathrm{Ca}_{3}\left(\mathrm{PO}_{4}\right)_{2}\right)$ or octacalcium phosphate (OCP, $\left.\mathrm{Ca}_{8} \mathrm{H}_{2}\left(\mathrm{PO}_{4}\right)_{6}\right)$ produced in aqueous solutions $(1.5-1.33)^{[58]}$. This correlates well with the XRD patterns (Fig. 3.25, p. 76): the width and low intensity of the peaks suggest that HAp is poorly crystalline. Bone apatite also contains a high amorphous content. Wopenka et al. ${ }^{[5]}$ related the concentration of carbonate in bone or dentin with the constrictions of the bone crystallites to the nanometer scale and pointed out that carbonate substituting ions could modify not only its crystal lattice, but also its growth morphology from needles to platelets.

Longer times of immersion in $\mathrm{SBF}$ lead to $\mathrm{Ca} / \mathrm{P}$ values approximating to the physiological ratio, while the crystallinity of the formed layers increases. This is in agreement with the literature. It is well established that HAp formation from metastable aqueous solutions is usually preceded by a precursor phase, most commonly ACP or OCP ${ }^{[58]}$. These precursor calcium phosphates then hydrolyze into the more thermodynamically stable HAp. In fact, HAp is the only thermodynamically stable calcium phosphate that exists in aqueous solution at a $\mathrm{pH}$ greater than $4.2^{[59]}$.

Apatites deposited in a solution often replace the $\mathrm{Ca}^{2+}$ ion site with small amounts of $\mathrm{Na}^{+}, \mathrm{Mg}^{2+}$ or $\mathrm{K}^{+}$ions, which lower the $\mathrm{Ca} / \mathrm{P}$ molar ratios ${ }^{[56]}$. The presence of 
these ions in the crystalline network of the apatite was evaluated by the $(\mathrm{Ca}+\mathrm{Mg}+\mathrm{Na}+\mathrm{K}) / \mathrm{P}$ ratio, though a portion could be merely adsorbed onto the surface of the apatite ${ }^{[54]}$. Despite the fact that there is abundant $\mathrm{Cl}^{-}$in the human body or in SBF, its large ionic size hinders its incorporation into the crystal lattice [5]. For the first stages of immersion in SBF there is a considerable difference between $\mathrm{Ca} / \mathrm{P}$ and $(\mathrm{Ca}+\mathrm{Mg}+\mathrm{Na}+\mathrm{K}) / \mathrm{P}, \mathrm{Na}^{+}$and $\mathrm{Mg}^{2+}$ being the main contributors, but afterwards these ratios are more similar to the $\mathrm{Ca} / \mathrm{P}$ relationships. Table 3.2 in p. 72 also shows the changes in the $\mathrm{Na} / \mathrm{Ca}, \mathrm{Mg} / \mathrm{Ca}$ and $\mathrm{K} / \mathrm{Ca}$ atomic ratios of the surfaces of the different samples. The fact that the $\mathrm{Mg} / \mathrm{Ca}$ and $\mathrm{K} / \mathrm{Ca}$ atomic ratios are very low and do not vary significantly may be attributed to the fixed $\mathrm{Na} / \mathrm{Ca}$ and $\mathrm{Mg} / \mathrm{Ca}$ atomic ratios of the solutions, whereas the higher $\mathrm{Na} / \mathrm{Ca}$ ratios would be attributed to the adsorption of $\mathrm{NaCl}$ from the SBF.

\subsubsection{On the structural changes of the nanohybrids when immersed in SBF}

According to recent works ${ }^{[52,58,75,60]}$ the carboxyl and hydroxyl groups of the surface of the copolymer have strong enough negative dipoles so as to interact electrostatically with $\mathrm{Ca}^{2+}$ ions from the SBF and form complexes. Phosphate ions may then bond with calcium forming calcium phosphate. The $\mathrm{Ca}^{2+}$ ions adsorbed by the copolymer can contribute to the formation of additional nucleating sites. Zainuddin et al. ${ }^{[52]}$ observed an extensive deposition of HAp in PHEMA hydrogels on the surface and also inside the hydrogel, and attributed it to the presence of functional groups able to chelate $\mathrm{Ca}^{2+}$ ions, and to the swelling ability that facilitates the diffusion of ions into the hydrogel. Among the three types of oxygen atoms present in PHEMA, $\mathrm{C}=\mathrm{O}, \mathrm{C}-\mathrm{O}$ and $\mathrm{OH}$, the hydroxyl oxygen seemed to be the most sensitive for complexation with $\mathrm{Ca}^{2+}$ ions ${ }^{[52]}$. This contrasts with the results here obtained for PHEA.

Silanol groups have higher potential for induction of apatite nucleation than carboxyl or hydroxyl groups and enhance dipole interactions ${ }^{[53]}$. However, the rate of apatite precipitation follows the sequence H10, H15, H20 > H05 > H00 > H30, 


\section{Discussion}

i.e., it achieves a maximum at an intermediate silica concentration, and is faster in the copolymer than in H30. The EDS images of the fractured H15 and H30 samples after 35 days in SBF (Fig. 3.27, p. 77 and Fig. 3.30, p. 80), and their corresponding spectra suggest structural changes taking place in the nanohybrids when immersed in SBF being dependent on their silica content. The apatite nucleation mechanism has been briefly elucidated. In the H15 hybrids, the silica network has dissolved and completely disappeared near the surface, leading to a gradient from the surface to a depth of $48 \mu \mathrm{m}$, where the composition is again that of the original hybrid. The HAp grows continuously into the material: $\mathrm{Ca}, \mathrm{P}$, but also $\mathrm{Na}, \mathrm{Mg}$ and $\mathrm{Cl}$ ions diffuse to the interior of the hybrid, giving rise to a strongly adhered coating layer. It seems that fairly strong bonds are formed between the polar groups of the material and the calcium ions of the apatite layer. On the contrary, in the H30 hybrids the silica network does not dissolve and consequently the HAp coating has a lower adhesive strength. This different behaviour of the silica networks in the different hybrids affects the nature of the heterogeneous nucleation, which occurs in the formation of the first HAp layer. This first layer will be differently anchored to the hybrid's surface, and thus all the subsequent layers will be affected to some degree.

The different growth modes of nucleation of the apatite layer can be explained on the basis of the different morphologies of the nanohybrids as regards their silica network structure. As demonstrated by our previous results and by results on the related $\mathrm{PHEA} / \mathrm{SiO}_{2}$ system ${ }^{[149]}$, the degree of connectivity of the nanosilica network in our $\mathrm{P}(\mathrm{EMA}-\mathrm{co}-\mathrm{HEA}) / \mathrm{SiO}_{2}$ hybrids depends on the amount of silica in the sample: for low silica contents the inorganic phase consists of disconnected nanodomains uniformly dispersed in the organic polymer matrix. The network terminal groups at the surfaces of these domains are non-condensed silanol groups. They increase the polarity or wettability of the nanocomposite surface. For higher silica concentrations the network percolates and becomes a continuous network, interpenetrated with the organic polymer matrix. This percolation threshold seems to be a value somewhat around a $15 \%$ of silica mass fraction in the hybrid. Percolation of the silica network is accompanied by a drastic decrease of the free, non-condensed silanol groups on a unit silica mass basis (Figure 4.1), which thus 
cease to be available. According to this, the dissolution of the silica network in nanocomposites of about to percolate silica concentrations, such as the H15 sample, is facilitated by the presence of large numbers of silanol terminal groups leading to low-molecular-weight silicates able to diffuse from the hybrid and the relative expansion of the hybrid structure. In this reaction zone of a few $\mu \mathrm{m}$ (Fig. 3.29, p. 79) calcium and phosphate ions can easily diffuse and penetrate the material and interact with the polar groups to form calcium phosphates. The apatite growth continues at the interface hybrid-solution leading to a strongly adhered apatite layer. For superpercolating silica concentrations, such as in the H30 sample, the expansion of the hybrids is constrained, and the more perfectly packed silica network contains fewer silanol groups, and thus silica dissolution and the $\mathrm{Ca}^{2+}$ diffusion are decreased. Therefore, the HAp nuclei can only grow from the preexisting nucleating functional groups available at the surface.

The bioactivity or HAp nucleating ability of the H30 hybrid sample is even lower than that of the copolymer. This can be explained as a consequence of a lower polarity in the case of the H30 hybrid (Table 3.1, p. 57), and of a second factor, which would also explain why the $\mathrm{P}$ (EMA-co-HEA) copolymer is more bioactive than the pure PEMA homopolymer. This factor is the network expansion. The presence of HEA monomer units in the $\mathrm{P}$ (EMA-co-HEA) copolymer lowers the glass transition temperature and the modulus of the copolymer with respect to those of pure PEMA and, moreover, when in an aqueous environment facilitates the network swelling. This swelling increases the number of polar groups available on a unit area basis by exposing them more efficiently. This would explain the greater bioactivity of $\mathrm{P}$ (EMA-co-HEA) 70/30 wt\% with respect to PEMA. However, the PHEA homopolymer does not nucleate HAp. This can be attributed to its enhanced molecular mobility in comparison with the copolymer, or also with PHEMA ${ }^{[52]}$, which are glassy at the temperature of the test. The hydroxyl groups of PHEA can be easily reorganized when immersed in SBF due to this enhanced molecular mobility, and absorb water likely more efficiently than they attract $\mathrm{Ca}^{2+}$ ions to nucleate HAp. 


\section{Discussion}
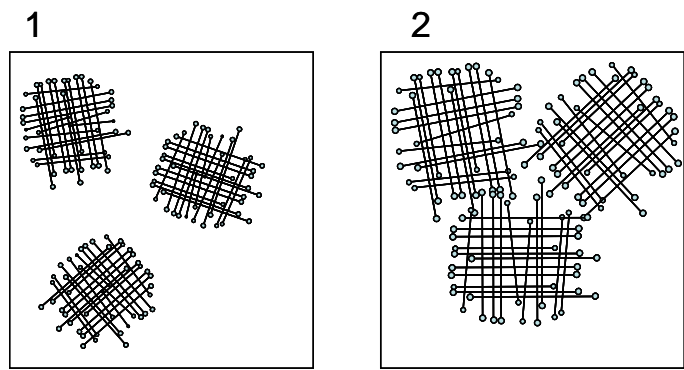

$m_{\mathrm{SiO}_{2}, 1}<m_{\mathrm{SiO}_{2}, 2}<m_{\mathrm{SiO}_{2}, 3}$
$n_{\mathrm{OH}, 1}<n_{\mathrm{OH}, 2}>n_{\mathrm{OH}, 3}$

$n_{O H, 2}=\max$

Figure 4.1 Sketches of different silica network structures: (1) low concentration subpercolating silica, (2) higher concentration, about to percolate silica, and (3) highest concentration, superpercolating silica.

— stands for ...-O-Si-O-Si-O-...; — stands for ...-O-Si-OH 


\subsection{Surface treatments as a means of reducing the apatite nucleation induction times}

The presence of the peak ascribed to $\mathrm{Na}$ in the EDS spectra after the $\mathrm{NaOH}$ treatment (Table 3.3, p. 84), indicates that the surface of the specimens was partially hydrolyzed by the $\mathrm{NaOH}$ treatment and the surfaces were provided with Na-containing groups. The large amount of $\mathrm{Na}$ in the copolymer and the practically absence of $\mathrm{Si}$ in $\mathrm{H} 15$ and $\mathrm{H} 30$ indicate that the $\mathrm{NaOH}$ treatment notably modifies the copolymer chains at the surface by forming sodium carboxylate in the lateral chains, while seemingly hydrolyzes the silica network, releasing soluble silicates and rendering (at least) the surfaces of the hybrids free of silica. Other authors introduced carboxylate groups in poly(E-caprolactone) ${ }^{[102]}$ and carboxymethyl chitin ${ }^{[100]}$ by $\mathrm{NaOH}$ and $\mathrm{Ca}(\mathrm{OH})_{2}$ treatments, respectively, to confer bone-bonding ability to the former and enhance the catalytic effect of the carboxyl groups in the latter. Herein, the carboxylate formed groups are effective in inducing apatite nucleation (Fig. 3.31, p. 82) with typical needle-like nanocrystals forming globular or cauliflower structures on the copolymer within 7 days, but the scattered cauliflowers formed do not merge to form a continuous layer after more than 14 days. It occurred similarly on the non-treated copolymer, so the $\mathrm{NaOH}$ treatment did not reduce its induction time. As stated above, the apatite nucleating potential of the non-treated copolymer is due to its lateral carboxylate and hydroxyl groups. They probably interact electrostatically with $\mathrm{Ca}^{2+}$ ions from the SBF to form complexes, which then attract phosphate ions to form calcium phosphates. On the $\mathrm{NaOH}$-treated copolymer, apatite deposition is initiated by exchange of $\mathrm{Na}^{+}$ions with $\mathrm{Ca}^{2+}$ ions from the medium, so the formed apatite layer is bonded to the carboxylate groups by ionic interactions ${ }^{[102]}$. If these hypotheses are true, then it would be reasonable to think that the apatite deposited on the $\mathrm{NaOH}$-treated copolymer would be more strongly anchored to the surface than that grown on non-treated ones. 


\section{Discussion}

Besides, the treated nanohybrids required longer times to induce the nucleation than the non-treated samples. On the non-treated nanohybrids, the heterogeneous nucleation to form the first apatite layer depended on the amount of silica and the nanostructure of silica in the organic polymeric matrix. In the NaOH-treated $\mathrm{H} 15$ and H30 samples, silica seems to be absent or not available at the surface for apatite nucleation, and thus bioactivity is only due to the carboxylate groups of the organic phase. The density and continuity of the silica network hindering the polymer network swelling could be responsible of the longer induction times for HAp nucleation of both nanohybrids with respect to the copolymer.

The CaP treatment after the $\mathrm{NaOH}$ treatment initiates heterogeneous growth of calcium phosphates in SBF instantaneously, as assessed by the SEM images (Fig. 3.33 , p. 87), although the formed apatite cauliflowers within short times in SBF are not very well defined and include a large quantity of salts from the SBF. The wrinkled aspect of the surfaces is probably due to shrinkage. The percentage of calcium phosphate deposited on the surfaces decreases in the order: $\mathrm{H} 00>\mathrm{H} 15>\mathrm{H} 30$. A longer CaP treatment would probably substitute the remaining $\mathrm{Na}$ ions by calcium phosphate nuclei. Bioactivity in CaP-treated samples is due only to carboxylate groups, since there are not silanol groups available at the surface. Oyane et al. ${ }^{[102]}$ proposed the following mechanism for the nucleation of calcium phosphate during the alternate soaking process. When the $\mathrm{NaOH}$-treated sample is dipped in the calcium ion solution, the sodium carboxylate groups attract calcium ions from the solution by an ion-exchange reaction. When the specimen is subsequently dipped in the phosphate ion solution, the calcium ions attract negatively charged phosphate ions from the solution. As a result, a certain kind of amorphous calcium phosphate is deposited on the specimen surface with an anchoring effect of the carboxylate groups. These calcium phosphates act as apatite nuclei or precursors of apatite, and spontaneously grow into the apatite layer in SBF, without any induction period, by consuming calcium and phosphate ions from the solution. These amorphous structures provide secondary nucleation sites that nucleate with time apatite cauliflowers of needle-like crystals, with $\mathrm{Ca} / \mathrm{P}$ ratios approximating to those of physiological (1.65) or stoichiometric (1.67) HAp ${ }^{[54]}$. This stabilization of amorphous calcium phosphates to poorly crystalline HAp 
seems to occur as well in the $\mathrm{NaOH}$-treated samples at the end of the test. The large amounts of $\mathrm{NaCl}$ adsorbed are seemingly due to the high content of $\mathrm{NaCl}$ in $\mathrm{SBF}$, but the release of $\mathrm{Na}^{+}$ions from the samples to the solution could also contribute to this effect. 


\section{5 $\mathrm{P}($ EMA-co-HEA $) / \mathrm{SiO}_{2}$ scaffolds mimicking natural dentin structure:} structure, characterization and bioactivity

Hybrid scaffolds of P(EMA-co-HEA) 70/30 wt $\% / \mathrm{SiO}_{2}$ were successfully obtained with varying proportions of silica up to $20 \mathrm{wt} \%$ (Fig. 3.38, p. 92), using a polyacrylonitrile fibres template that was eventually eliminated to leave homogeneously distributed aligned tubular pores of approximately $8 \mu \mathrm{m}$ of diameter. Mixtures with higher silica contents were too viscous and did not soak well the PAN fibers. The microscope images of the obtained synthetic scaffolds show that they resemble very much natural dentin (Fig. 1.2, p. 2) with regard to the structure and distribution of the pores, being the pores diameter still slightly large. This is of major relevance because this is, up to our knowledge, the first time that a synthetic scaffold i) organic/inorganic nanocomposite, ii) that attempts to mimic natural dentin structure is proposed.

Neither the pore diameter nor the distribution seem to vary with the composition of the scaffolds. The porosity (Table 3.7, p. 93) of the PHEA scaffold is lower than that of the PEMA scaffold because of the shrinkage of PHEA, which is a rubber at room temperatures while PEMA is a glass in these conditions. The porosity of the hybrids does not seem to be very much affected by the different silica contents and takes in all cases similar values to that of PEMA, because their high $T_{g}$ s and constraint of the silica network impede the shrinkage.

The compressive elastic modulus (Table 3.8, p. 94) of the H00 scaffold is very close to that of PEMA. Silica contents above $5 \mathrm{wt} \%$ lead to an increase in the compressive Young modulus over the PEMA value, being higher than the corresponding values of the bulk samples. This could be attributed to a preferential organization of the silica network, and consequently of the organic network, when the polymerization is carried out in the presence of the parallel fibres template. 
Furthermore, the elastic modulus of the hybrids increases with the HAp coating. The HAp-coated H15 scaffold has an elastic modulus of $8192 \mathrm{MPa}$, which is still lower than that of human dentin, $14.47 \mathrm{GPa}{ }^{[153]}$. When implanted in vivo, the regenerated mineralized tissue is expected to contribute to the definitive compressive modulus.

The bioactivity of the H15 scaffold was assessed, not to confirm the previous findings on the bulk materials, but to evaluate the effect of the scaffolds architecture on the apatite coating formation. Problems such as the influence of the strongly curved geometries of the substrate onto which the apatite layer grows and whether this layer would blind the tubule apertures needed to be investigated.

The immersion in SBF for 7 days does not seem to be sufficient to induce the nucleation of apatite in the interior of the tubules of the H15 scaffolds (Fig. 3.40, p. 96). Nonetheless, the soaking in $2 \times \mathrm{xBF}$ during 7 more days promotes the accelerated deposition of aggregates on the surface, including the inner surfaces of the pores, without closing them (Fig. 3.41, p. 97). These aggregates present the typical cauliflower structures of apatite needle-shaped crystals observed previously on the bulk samples, with a composition similar to that of physiological HAp. As a consequence, the average tubule diameter decreases from 8 to approximately $5 \mu \mathrm{m}$. This new pore diameter resembles more that of the natural dentinal tubule, being thus more convenient for the proposed application. The apatite coating of the pores and the consequent decrease in tubules diameter and mechanical reinforcement are very interesting features in the way to mimic natural dentin with regard to its structure and mechanical properties. 



\section{Chapter 5}

\section{Conclusions}

On the structure of $\mathrm{SiO}_{2}$ in the $\mathrm{P}(\mathrm{EMA}-$ co-HEA) polymeric matrix

1. Organic/inorganic nanohybrid materials of poly(ethyl methacrylate-cohydroxyethyl acrylate) 70/30 wt\%/silica, $\mathrm{P}(\mathrm{EMA}-\mathrm{co}-\mathrm{HEA}) / \mathrm{SiO}_{2}$, were successfully obtained with varying proportions of silica up to $30 \mathrm{wt} \%$. The synthesis procedure consisted in the copolymerization of the organic monomers EMA and HEA during the simultaneous acid-catalyzed sol-gel polymerization of TEOS.

2. The observations from the FTIR spectra and the silica quantifications by EDS and TGA indicate that the silica precursor was efficiently hydrolyzed and condensed to silica during the sol-gel process, and silica was found to be homogeneously distributed in the polymeric matrix both in the bulk and at the surface. The swelling measurements pointed out to the absence of significative heterocondensation between silica and the organic copolymer.

3. The silica sol-gel polymerization was faster than the organic radical polymerization, giving place to weakly crosslinked or branched nanometer-sized silica networks. In the hybrids with low silica contents, the silica nanodomains (with an average diameter about $10 \mathrm{~nm}$ ) were uniformly interdispersed in the organic phase, and tended to aggregate in larger regions leaving spaces of tens of nanometers where the organic network occurred. These aggregates of silica nanoparticles became denser as viewed by TEM with the increase of the silica content. The silica sol-gel polymerization occurring faster than the organic copolymerization, and the small size of the silica aggregates account for the optical transparency of the nanohybrids. Around 15 wt\% of silica, the inorganic network 


\section{Conclusions}

seems to percolate and coalesce to form a co-continuous interpenetrated network. The surpassing of this threshold silica content was confirmed by the continuity of the pyrolises residues. Higher silica contents produce co-continuous interpenetrated structures, until the elementary inorganic domains are no longer detectable by TEM in the hybrid with $30 \mathrm{wt} \%$ of silica.

4. The incorporation of hydrophobic EMA in the organic phase makes the copolymer network much more rigid, i.e., with a much higher $T_{g}$ than the rubbery PHEA network, which explains its low equilibrium water content resemble that of PEMA and is lower than estimated. Even though the copolymer swells well in a water/ethanol mixture, it occurs similarly with the equilibrium water/ethanol content, since it is a random copolymer.

5. The swelling ability in water of the nanohybrids is basically due to their HEA component, which is as hydrophilic in the nanocomposites as it is in the copolymer. The different morphology of the nanohybrids is clearly manifested in the equilibrium water/ethanol content. The relatively high amount of noncondensed Si-OH terminal groups on the surfaces of the disconnected silica nanoparticles, conjointly with the organic network expansion still not hindered by a rigid silica skeleton could account for the initial steep increase in the water/ethanol swelling ability of the nanocomposites with low silica contents. The increase in the silica contents and formation of interpenetrated networks, co-continuous with the copolymer, hinders the swelling of the organic chains, and renders less hydrophilic silanol groups available for swelling. Finally, the organic matrix in the nanohybrid with $30 \mathrm{wt} \%$ of silica behaves similarly to PEMA.

6. $\mathrm{P}(\mathrm{EMA}-\mathrm{co}-\mathrm{HEA}) / \mathrm{SiO}_{2}$ nanohybrids with silica contents of $15 \mathrm{wt} \%$ and above present interesting morphologies with the organic/inorganic phases in the form of interpenetrated networks. Besides, the simplicity of the synthesis offers the possibility of controlling the architecture of the obtained nanocomposites. 


\section{Characterization of $\mathrm{P}(\mathrm{EMA}-\mathrm{co}-\mathrm{HEA}) / \mathrm{SiO}_{2}$ nanocomposites}

7. The different structures of silica within the copolymeric matrix modify the characteristics of the surfaces. The surface tension and polarity of the surfaces increase with silica contents between 5 and $20 \mathrm{wt} \%$, owing to the increase in the number of silanol terminal groups at the surfaces. However, higher silica contents render less silanol non-condensed boundary groups when a true continuous silica interpenetrated network has formed, and the surfaces behave again as the copolymer did.

8. The calorimetric and dynamic-mechanical measurements confirm the absence of phase separation in the organic phase and the homogeneity of the copolymer, with a single weak calorimetric glass transition, but a sharp associated relaxation process, located between those of the homopolymers. The increase in the glass transition temperature and, more clearly, the shift of its associated mechanical relaxation to higher temperatures, is attributed to the restriction of the copolymer chains mobility as they are more intertwined with the rigid silica network. This reinforcing effect of silica is also reflected in the increase of the compressive elastic modulus of the nanocomposites.

9. Although the presence of silica hinders the polymer chain motions (confines them in nanometric domains), smoothing the glass transition process and broadening its mechanical relaxation, practically all the copolymer chains in the nanocomposites are able to undergo conformational motions at the glass transition. The increase of the rubbery storage modulus from $10 \mathrm{wt} \%$ of silica points out to the silica network continuously extending throughout the samples and constraining the long distance cooperative motions of the copolymer chains. This is consistent with the hypotheses relating to the silica structure in the organic matrix.

10. At supra- $T_{q}$ temperatures, a slight aging phenomenon occurs, since molecular motions allow condensations within the silica network (which remained frozen within the vitrified organic phase at ambient temperatures) to start again. Water expelled in these reactions could also contribute to the lower thermal stability of the nanocomposites. 


\section{Conclusions}

11. Nanohybrids with intermediate silica contents (10-20 wt\%) exhibit an interesting equilibrium between: (i) mechanical reinforcement attained by thereabout co-continuous interpenetrated silica networks, (ii) improved swelling ability still not hindered by a too rigid perfect silica skeleton, and (iii) enhanced surface reactivity or hydrophilicity due to the still elevated relative content of polar silanol terminal groups.

\section{Bioactivity of $\mathrm{P}(\mathrm{EMA}-\mathrm{co}-\mathrm{HEA}) / \mathrm{SiO}_{2}$ nanocomposites}

12. The homopolymers PEMA and PHEA do not induce the apatite growth efficiently. The copolymer induces the nucleation of apatite crystals more slowly than the hybrids with 5-20 wt\% silica, but faster than that with $30 \mathrm{wt} \%$. Polar carboxyl and hydroxyl groups of the copolymer are effective apatite nucleators. They likely interact electrostatically with $\mathrm{Ca}^{2+}$ ions from the SBF to form complexes, which then attract phosphate ions to form calcium phosphate. The adsorption of $\mathrm{Ca}^{2+}$ ions can contribute to the formation of additional nucleating sites in the interior. The behaviour of the copolymer demonstrates that the presence of the carboxyl and hydroxyl groups act synergistically in inducing the apatite nucleation and growth, probably with an effect of the network expansion in an aqueous medium leading to an exposure of a larger number of nucleating sites and to enhanced intrapolymer diffusion. The behaviour of the homopolymers indicates that the presence of hydroxyl groups is necessary, but with restricted mobility.

13. Concerning the hybrids, the heterogeneous nucleation to form the first apatite layer depends on the amount of silica and the nanostructure of the silica network. In nanohybrids with intermediate silica contents (10-20 wt\%), the dissolution of silica at the surface is facilitated by the presence of relatively large numbers of non-condensed silanol terminal groups in the network due to the more disconnected topology of the silica phase; the silica solution process releases soluble silicates and renders an interface layer rich in silanol groups. In this reaction zone of a few $\mu \mathrm{m}$ calcium and phosphate ions are adsorbed and interact with the polar groups of soluble and hydrated silica to form calcium phosphates. The apatite 
growth continues at the interface hybrid-solution leading to a strongly adhered apatite layer. After 7 days, the surfaces are completely covered with apatite, and they even provide secondary nucleation sites for the precipitation of spherical structures with the same needle-like morphology. Above a silica concentration of approximately $20 \mathrm{wt} \%$, the continuously extended dense silica network hinders the organic polymer network expansion and the diffusion of $\mathrm{Ca}^{2+}$ ions, and thereby exhibits a lower density of non-reacted surface silanols, leading to a lesser degradation of the silica network at the interface. Therefore, the nucleation of apatite occurs even more slowly than on the copolymer.

14. Once apatite nuclei have been formed, the growth of the apatite layer and formation of successive layers occurs very rapidly in all cases, consuming calcium and phosphate ions from the SBF. The initially amorphous calcium phosphate, containing other ions such as $\mathrm{CO}_{3}{ }^{2-}, \mathrm{Na}^{+}, \mathrm{K}^{+}$or $\mathrm{Mg}^{2+}$, stabilizes leading to lowcrystalline needle-shaped polycrystals of carbonated-HAp, with $\mathrm{Ca} / \mathrm{P}$ ratios near the physiological HAp ratio.

\section{Surface treatments as a means of reducing the apatite nucleation induction times}

15. The $\mathrm{NaOH}$ treatment here applied is not effective by itself in shortening the HAp induction time. It introduces sodium carboxylates in the copolymer lateral chains of the surface while hydrolyzes the silica network, releasing soluble silicates and rendering the surfaces of the hybrids free of silica. Consequently, bioactivity is only due to the carboxyl groups of the organic phase. The NaOH-treated and the non-treated copolymer displayed similar apatite nucleation ability, whereas the $\mathrm{NaOH}$-treated hybrids required longer nucleation induction times. Maybe a suitable dissolution extent of the silica network so as to improve bioactivity of the nanohybrid with $30 \mathrm{wt} \%$ of silica could be attained by controlling the duration of the $\mathrm{NaOH}$ treatment.

16. The posterior $\mathrm{CaP}$ treatment is able to coat the surfaces of the samples with a calcium phosphate layer within minutes, the amount of calcium phosphate being dependent of the previous Na deposition. These amorphous or non-apatitic calcium phosphates act as precursors of apatite, and spontaneously grow, without 


\section{Conclusions}

any induction period, by consuming calcium ions and phosphate ions from the solution and adsorbing a large quantity of salts from the SBF. The initial amorphous structures provide secondary nucleation sites to form successive layers, which stabilize with time rendering HAp layers of polycrystalline cauliflowers with needle-like structure and $\mathrm{Ca} / \mathrm{P}$ ratios approximating to those of physiological HAp.

\section{On the $\mathrm{P}(\mathrm{EMA}-\mathrm{co}-\mathrm{HEA}) / \mathrm{SiO}_{2}$ scaffolds mimicking natural dentin structure}

17. Silica-based organic-inorganic nanocomposite scaffolds, with varying proportions of silica up to $20 \mathrm{wt} \%$ were prepared with the aim of mimicking the structure and properties of the extracellular matrix of natural dentin. The scaffolds were obtained by the fibre-templating fabrication method, using polyacrylonitrile fibres templates that were eliminated after the polymerization of the hybrid mixtures to leave scaffolds with homogeneously distributed aligned tubular pores of approximately $8 \mu \mathrm{m}$ of diameter.

18. The porosity of the nanohybrid structures, about $50 \%$, was not affected by the different silica contents. The compressive elastic modulus increased with the silica content, taking in all cases values higher than those of the corresponding bulk samples, likely due to a preferential organization of the silica network in presence of the parallel fibres template. The scaffold with $15 \mathrm{wt} \%$ of silica pyrolyzed leaving a continuous porous scaffold of twisted shrunk pores as residue.

19. The $15 \mathrm{wt} \%$ nanohybrid scaffolds were found to be bioactive in an in vitro test in SBF during 14 days, after which both the exterior transversal surface and the inner surface of the pores were covered of typical apatite cauliflower structures, with a composition similar to that of stoichiometric HAp. This apatite coating reinforced mechanically the original scaffold and decreased the pores diameter to values more similar to those of the dentinal tubules.

20. The $\mathrm{P}(\mathrm{EMA}-c o-\mathrm{HEA}) / \mathrm{SiO}_{2}$ nanohybrid scaffolds with intermediate silica contents here obtained, resemble natural dentin architecture, possess compatible mechanical properties and apatite nucleation ability. These features are expected to facilitate the integration in the host mineralized tissue and stimulate the 
differentiation of pulpal cells and the invasion of the tubules by new odontoblast prolongations when implanted in vivo, thereby guiding dentin tissue regeneration. 



\section{Chapter 6}

\section{Appendix: Biological response}

\subsection{Culture in vitro}

Hybrids of P(EMA-co-HEA) with 0, 15 and $30 \mathrm{wt} \% \mathrm{SiO}_{2}$ (H00, H15 and H30) were synthesized as sheets, and HAp coated through the immersion in SBF during 35 days. The SBF was changed to a $2 \times \mathrm{SBF}$ solution with periodical renewal after the seventh day. Human dental pulp fibroblasts were cultured in vitro on the HAp coated hybrids for 3 and 8 days. These cultures were performed by Elisa Costa Martínez in the Centre for Biomaterials and Tissue Engineering, Valencia (Spain). The influence of the surface apatite coating on the nanohybrid samples on the viability, proliferation, differentiation and morphology of dental pulp fibroblasts was evaluated in vitro.

Cell morphology was observed by contrast phase light microscopy, CPLM, (results not shown) and SEM. Biocolonization was observed in at least 8 samples per composition. The SEM images in Figure 6.1 show the morphology of the dental pulp fibroblasts on the cauliflower structures of the HAp layer on the different substrates after 8 days of culture. Cells tend to spread so as to maximize the contact area with the surface. 

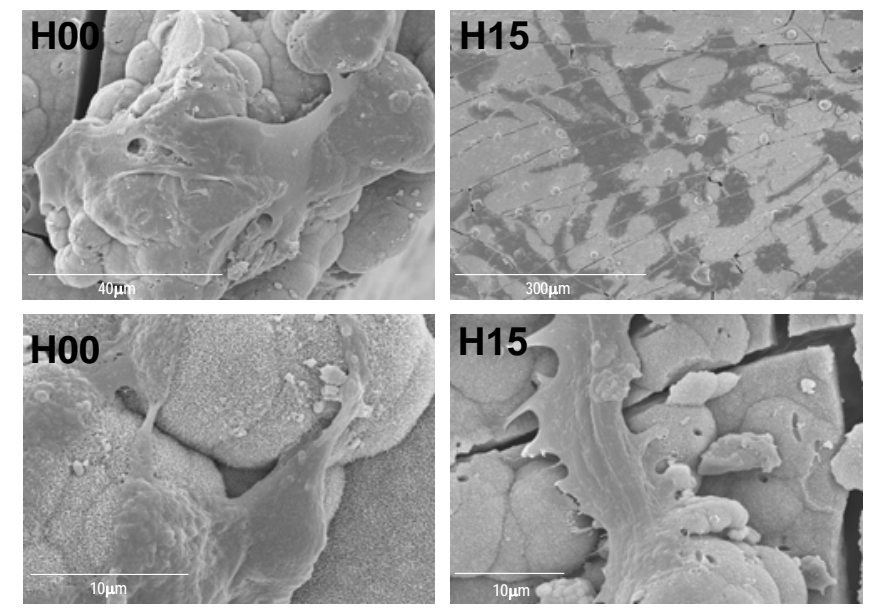

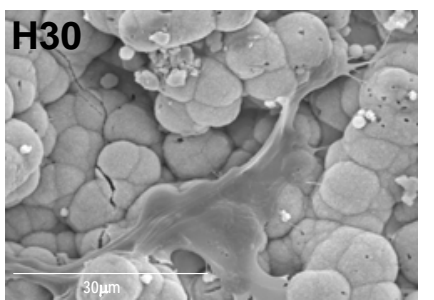

$\mathrm{H} 30$

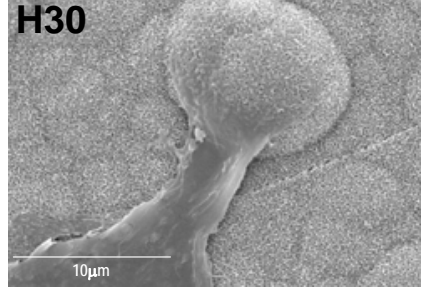

Figure 6.1 SEM images of the monolayer culture of dental pulp fibroblasts on H00 SBF35, H15 SBF35 and H30 SBF35 after 8 days of culture.

Cell viability and proliferation was assessed by the tetrazolium salt MTT colorimetric assay. The results showed that cells were able to cover the materials and that there was no significant difference among the H00, H15 and H30 HApcoated nanohybrids after 35 days in SBF, Figure 6.2. The error bars represent the confidence interval for the average. The F-Snedecor test $(\alpha=0.05)$ showed no significant difference between the samples with different silica content.

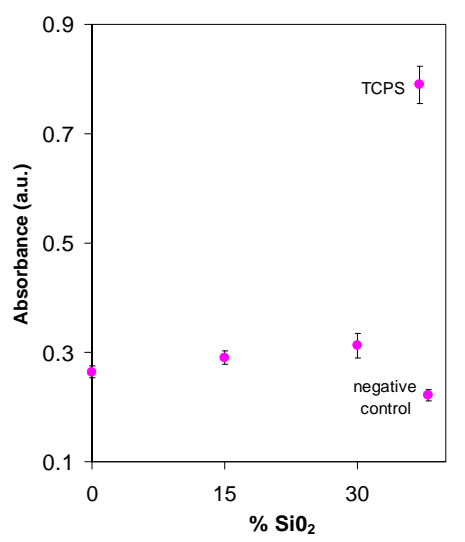

Figure 6.2 MTT colorimetry results on H00 SBF35, H15 SBF35 and H30 SBF35 after 8 days of culture. 
With the aim of investigating if there was any change in cell viability/proliferation on a completely mineralized layer for a longer time, cell culture was repeated with H15 SBF35 substrates for 16 days. The MTT assay of the cells cultured at 7 and 16 days (Figure 6.3) shows that cell population on the H15 sample considerably increases from day 7 to day 16 as a consequence of an excellent adaptation of the dental pulp fibroblasts to the HAp-coated surface.

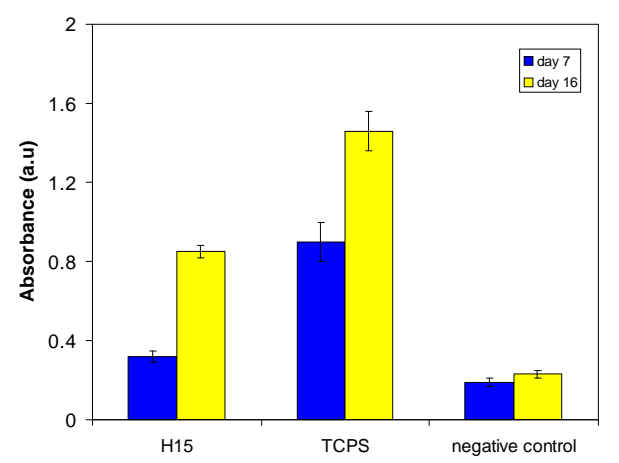

Figure 6.3 MTT colorimetry results on H15 SBF35 after different times of culture.

These results show that human dental pulp fibroblasts colonize the apatite layer; cells maintain the viability and proliferate on the HAp surfaces. As expected, the different samples behaved similarly, since they were completely HAp covered after 35 days in SBF. 
6. Appendix: biological response

\subsection{Subcutaneous implants in vivo}

Scaffolds of P(EMA-co-HEA) (H00), P(EMA-co-HEA) with 15 wt\% $\mathrm{SiO}_{2}$ (H15) and $\mathrm{P}\left(\mathrm{EMA}-\right.$-co-HEA) with $15 \mathrm{wt} \% \mathrm{SiO}_{2} \mathrm{HAp}$-coated in SBF during 14 days (H15 SBF14) were implanted subcutaneously in immunocompromised nude mice for 4 and 8 weeks. Some of the samples were immersed in a fibronectin solution overnight before the implantation. This is an ongoing work in collaboration with Dr. Carmen Carda Batalla (Pathology Department, Faculty of Medicine and Odontology, University of Valencia).

In the case of the implants performed with H00 scaffolds, the histologies showed a good implantation and neoangiogenesis, which was improved by fibronectin. The histologies of the explants of the H15 scaffolds displayed a structural pattern more similar to the dentinal one, also favoured by fibronectin. The histologies of the HAp coated H15 scaffolds showed the greatest cellularity in a dentinal pattern and neoangiogenesis. In this case fibronectin did not modify the results. Figure 6.4 displays some histologies as an example. 


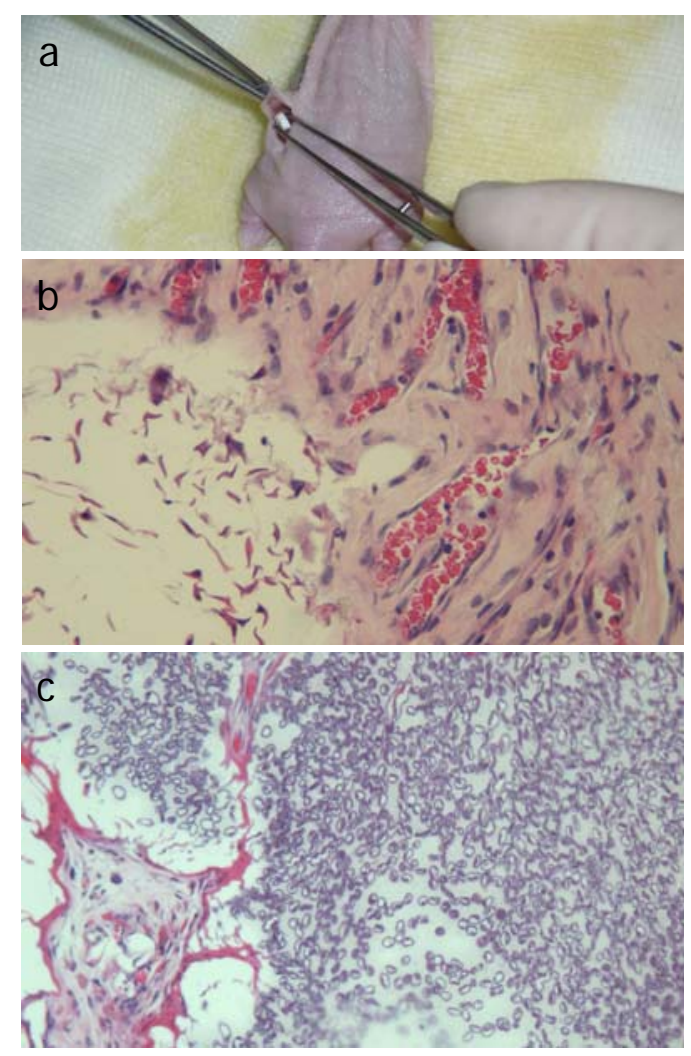

Figure 6.4 (a) Subcutaneous implantation of a scaffold in nude mice, (b) histology of the H00 scaffold (with fibronectin), (c) histology of the H15 SBF14 scaffold. 



\section{References}

1. Spencer P, Wang Y, Katz JL. Dentin. In: Akay M, ed. Wiley Encyclopedia of Biomedical Engineering. New Jersey: John Wiley \& Sons, 2006. pp. 1051-1060.

2. Bohl KS, Shon J, Rutherford B, Mooney DJ. Role of synthetic extracellular matrix in development of engineered dental pulp. J Biomater Sci: Polym Ed 1998; 9: 749-764.

3. Walker MP, Fricke B. Dentin-enamel junction of human teeth. In: Akay M, ed. Wiley Encyclopedia of Biomedical Engineering. New Jersey: John Wiley \& Sons, 2006. pp. 1061-1064.

4. Marshall GW, Marshall SJ, Kinney JH, Balooch M. The dentin substrate: structure and properties related to bonding. J Dent 1997; 25(6): 441-458.

5. Wopenka B, Pasteris JD. A mineralogical perspective on the apatite in bone. Mat Sci Eng C 2005; 25: 131-143.

6. Kinney JH, Pople JA, Marshall GW, Marshall SJ. Collagen orientation and crystallite size in human dentin: a small angle X-ray scattering study. Calcif Tissue Int 2001; 69: 31-37.

7. De Santis R, Ambrosio L, Nicolais L. Mechanical properties of tooth structures. In: Barbucci R. Integrated biomaterials science. Kluwer Academia/Plenum Publishers, New Cork, 2002. pp.: 589-599.

8. Fawcett DW, ed. Tratado de Histología. McGraw-Hill/Interamericana de España, Madrid, 2000. pp. 633-648.

9. About I, Bottero MJ, de Denato P, Camps J, Franquin JC, Mitsiadis TA. Human dentin production in vitro. Exp Cell Res 2000; 258: 33-41. 
References

10. Maciejewska I, Spodnik JH, Slawomir W, Domaradzka-Pytel B, Bereznowski Z. The dentin sialoprotein (DSP) expression in rat tooth germs following fluoride treatment: an inmunohistochemical study. Arch Oral Biol 2006; 51: 252-261.

11. Yelick PC, Vacanti JP. Bioengineered teeth from tooth bud cells. Dent Clin N Am 2006; 50: 191-203.

12. Zhang W, Walboomers XF, Wolke JGC, Bian Z, Fan MW, Jansen JA. Differentiation ability of rat postnatal dental pulp cells in vitro. Tissue Eng 2005; 11: $357-368$.

13. Yoshikawa M, Tsuji N, Toda T, Ohgushi H. Osteogenic effect of hyaluronic acid sodium salt in the pores of a hydroxyapatite scaffold. Mat Sci Eng C 2007; 27: 220-236.

14. Batouli S, Miura M, Brahim J, Tsutsui TW, Fisher LW, Gronthos S, Gehron Robey P, Shi S. Comparison of stem-cell-mediated osteogenesis and dentinogenesis. J Dent Res 2003; 82: 976-981.

15. Tziafas D, Smith AJ, Lesot H. Designing new treatment strategies in vital pulp therapy. J Dent 2000; 28: 77-92.

16. Goldberg M, Smith AJ. Cells and extracellular matrices of dentin and pulp: a biological basis for repair and tissue engineering. Crit Rev Oral Biol Med 2004; 15: $13-27$.

17. Téclès $\mathrm{O}$, Laurent $\mathrm{P}$, Zygouritsas $\mathrm{S}$, Burger A-S, Camps J, Dejou J, About I. Activation of human dental pulp progenitor/stem cells in response to odontoblast injury. Arch Oral Biol 2005; 50: 103-108.

18. Nakashima M. Bone morphogenetic proteins in dentin regeneration for potential use in endodontic therapy. Cytokine Growth F R 2005; 16: 369-76.

19. Murray PE, García-Godoy F, Hargreaves KM. Regenerative endodontics: a review of current status and a call for action. J Endod 2007; 33: 377-390.

20. Pinasco MR, Natali A, Loria $P$, Bolla M, Hagege FJ. Dental materials and implants. In: Barbucci R. Integrated biomaterials science. Kluwer Academia/Plenum Publishers, New Cork, 2002. pp.: 601-654. 
21. Moszner N, Salz U. New developments of polymeric dental composites. Prog Polym Sci 2001; 26: 535-576.

22. Langer R, Vacanti JP. Tissue engineering. Science 1993; 260: 920-926.

23. Abatangelo G, Brun P, Radice M, Cortivo R, Auth MKH. Tissue Engineering. In: Barbucci R. Integrated biomaterials science. Kluwer Academia/Plenum Publishers, New Cork, 2002. pp.: 885-946.

24. Grodzinski JJ. Polymers for tissue engineering, medical devices, and regenerative medicine. Concise general review of recent studies. Polym Adv Technol 2006; 17: 395-418.

25. Young CS, Terada S, Vacanti JP, Honda M, Bartlett JD, Yelick PC. Tissue engineering of complex tooth structures on biodegradable polymer scaffolds. J Dent Res 2002; 81: 695-700.

26. Buurma B, Gu K, Rutherford RB. Transplantation of human pulpal and gingival fibroblasts attached to synthetic scaffolds. Eur J Oral Sci 1999; 107: 282289.

27. Dobie K, Smith G, Sloan AJ, Smith AJ. Effects of alginate hydrogels and TGF- $\beta 1$ on human dental pulp repair in vitro. Connect Tissue Res 2002; 43: 387390.

28. Honda MJ, Tsuchiya S, Sumita Y, Sagara H, Ueda M. The sequential seeding of epithelial and mesenchymal cells for tissue-engineered tooth regeneration. Biomaterials 2007; 28: 680-689.

29. Young CS, Abukawa H, Asrican R, Ravens M, Troulis MJ, Kaban LB, Vacanti JP, Yelick PC. Tissue-engineered hybrid tooth and bone. Tissue Eng 2005; 11: 1599-1610.

30. Wang FM, Qiu K, Hu T, Wan CX, Zhou XD, Gutmann JL. Biodegradable porous calcium polyphosphate scaffold for the three-dimensional culture of dental pulp cells. Int Endodon J 2006; 39: 477-483.

31. Zhang W, Walboomers XF, van Kuppevelt TH, Daamen WF, Bian Z, Jansen JA. The performance of human dental pulp stem cells on different threedimensional scaffold materials. Biomaterials 2006; 27: 5658-5668. 
References

32. Yoshikawa M, Tsuji N, Toda T, Ohgushi H. Osteogenic effect of hyaluronic acid sodium salt in the pores of a hydroxyapatite scaffold. Mat Sci Eng C 2007; 27: $220-236$.

33. Hench LL. The story of Bioglass. J Mater Sci: Mater Med 2006; 17: 967-978.

34. Ben-Nissan B, Ylänen HO. Bioactive glasses and glass ceramics. In: Akay M, ed. Wiley Encyclopedia of Biomedical Engineering. New Jersey: John Wiley \& Sons, 2006. p. 354-366.

35. Kokubo T. Bioactivity of glasses and glass-ceramics. In: Ducheyne P, Kokubo T, Blitterswijk CA, eds. Bone-bonding Biomaterials. Leidendorp: Reed Healthcare Communications, 1992: pp. 31-46.

36. Bajpai PK, Billote WG. In: Bronzino JD, ed. The Biomedical Engineering Handbook. CRC Press, Florida, 1995: p.: 552.

37. Hench LL, Kokubo T. In: Black J, Hastings G, ed. Handbook of Biomaterials Properties. Chapman \& Hall, London, 1998: p. 355.

38. Kokubo T, Takadama H. How useful is SBF in predicting in vivo bone bioactivity? Biomaterials 2006; 27: 2907-2915.

39. Kokubo T. Bioactive glass ceramics: properties and applications. Biomaterials 1991; 12: 155-163.

40. Ohtsuki C, Kokubo T, Yamamuro T. Mechanism of apatite formation on CaO- $\mathrm{SiO}_{2}-\mathrm{P}_{2} \mathrm{O}_{5}$ glasses in a simulated body fluid. J Non-Cryst Solids 1992; 143: 8492.

41. Hench LL. Bioceramics. J Am Ceram Soc 1998; 81: 1705-1727.

42. Zhang K, Yan H, Bell DC, Stein A, Francis LF. Effects of materials parameters on mineralization and degradation of sol-gel bioactive glasses with 3Dordered macroporous structures. J Biomed Mater Res: A 2003; 66: 860-869.

43. Kawata M, Uchida H, Itatani K, Okada I, Koda S, Aizawa M. Development of porous ceramics with well-controlled porosities and pore sizes from apatite fibers and their evaluations. J Mater Sci: Mater Med 2004; 15: 817-823.

44. Ning CQ, Mehta J, El-Ghannam A. Effects of silica on the bioactivity of calcium phosphate composites in vitro. J Mater Sci: Mater Med 2005; 16: 355-360. 
45. Ribeiro CC, Barrias CC, Barbosa MA. Preparation and characterisation of calcium-phosphate porous microspheres with a uniform size for biomedical applications. J Mater Sci: Mater Med 2006; 17: 455-463.

46. Thian ES, Hunag J, Vickers ME, Best SM, Barber ZH, Bonfield W. Siliconsubstituted hydroxyapatite (SiHA): A novel calcium phosphate coating for biomedical applications. J Mater Sci 2006; 41: 709-717.

47. Jones JR, Ehrenfried LM, Hench LL. Optimising bioactive glass scaffolds for bone tissue engineering. Biomaterials 2006; 27: 964-973.

48. Kokubo T. Design of bioactive bone substitutes based on biomineralization process. Mater Sci Eng C 2005; 25: 97-104.

49. Li R, Clark AE, Hench LL. An investigation of bioactive glass powders by solgel processing. J Appl Biomat 1992; 2: 231-239.

50. Salinas AJ, Vallet-Regí M, Izquierdo-Barba I. Biomimetic apatite deposition on calcium silicate gel glasses. J Sol-Gel Sci Tech 2001; 21: 13-25.

51. Kim HM, Himeno T, Kokubo T, Nakamura T. Process and kinetics of bonelike apatite formation on sintered hydroxyapatite in a simulated body fluid. Biomaterials 2005; 26: 4366-4373.

52. Zainuddin, Hill DJT, Whittaker AK, Chirila TV. In-vitro study of the spontaneous calcification of PHEMA-based hydrogels in simulated body fluid. J Mater Sci: Mater Med 2006; 17: 1245-1254.

53. Kawai T, Ohtsuki C, Kamitakahara M, Hosoya K, Tanihara M, Miyazaki T, Sakaguchi Y, Konagaya S. In vitro apatite formation on polyamide containing groups modified with silanol groups. J Mater Sci: Mater Med 2007; 18: 1037-1042.

54. Kim HM, Kishimoto K, Miyaji F, Kokubo T, Yao T, Suetsugu Y, Tanaka J, Nakamura T. Composition and structure of the apatite formed on PET substrates in SBF modified with various ionic activity products. J Biomed Mater Res 1999; 46: 228-235.

55. Malkaj P, Pierri E, Dalas E. The crystallization of hydroxyapatite in the presence of sodium alginate. J Mater Sci: Mater Med 2005; 16: 733-737. 
References

56. Spanos N, Misirlis DY, Kanellopoulou DG, Koutsoukos PG. Seeded growth of hydroxyapatite in simulated body fluid. J Mater Sci 2006; 41: 1805-1812.

57. Dutour Sikiric M, Füredi-Milhofer H. The influence of surface active molecules on the crystallization of biominerals in solution. Adv Colloid Interfac 2006; 128-130: $135-158$.

58. Hutchens SA, Benson RS, Evans BR, O'Neill HM, Rawn CJ. Biomimetic synthesis of calcium-deficient hydroxyapatite in a natural hydrogel. Biomaterials 2006; 27: 4661-4670.

59. Vallet-Regí M, Rodríguez-Lorenzo LM, Salinas AJ. Synthesis and characterization of calcium deficient apatite. Solid State Ionics 1997; 101-103: 12791285 .

60. Oliveira AL, Malafaya PB, Reis RL. Sodium silicate gel as a precursor for the in vitro nucleation and growth of a bone-like apatite coating in compact and porous polymeric structures. Biomaterials 2003; 24: 2575-2584.

61. Tanahashi M, Yao $T$, Kokubo $T$, Minoda M, Miyamoto $T$, Nakamura $T$, Yamamuro T. Apatite coating on organic polymers by a biomimetic process. J Am Ceram Soc 1994; 77: 2805-2808.

62. Takadama H, Kim HM, Kokubo T, Nakamura T. Mechanism of biomineralization of apatite on a sodium silicate glass: TEM-EDX study in vitro. Chem Mater 2001; 13: 1108-1113.

63. Kim HM, Himeno T, Kawashita M, Kokubo T, Nakamura T. The mechanism of biomineralization of bone-like apatite on synthetic hydroxyapatite: an in vitro assessment. J R Soc Interface 2004; 1: 17-22.

64. Vallet-Regí M, Salinas AJ, Arcos D. From the bioactive glasses to the star gels. J Mater Sci: Mater Med 2006; 17: 1011:1017.

65. Devreux F, Barboux P, Filoche M, Sapoval B. A simplified model for glass dissolution in water. J Mater Sci 2001; 36: 1331-1341.

66. Rimer JD, Trofymluk O, Navrotsky A, Lobo RF, Vlachos DG. Kinetic and thermodynamic studies of silica nanoparticle dissolution. Chem Mater 2007; 19: 4189-4197. 
67. Siriphannon P, Kameshima Y, Yasumori A, Okada K, Hayashi S. Formation of hydroxyapatite on $\mathrm{CaSiO}_{3}$ powders in simulated body fluid. J Eur Ceram Soc 2002; 22: 511-520.

68. Pereira MM, Clark AE, Hench LL. Effect of texture on the rate of hydroxyapatite formation on gel-silica surface. J Am Ceram Soc 1995; 78: 24632468.

69. Takadama H, Kim HM, Miyaji F, Kokubo T, Nakamura T. Mechanism of apatite formation induced by silanol groups-TEM observation. J Ceram Soc Japan 2000; 108: 118-121.

70. Brinker CJ, Keefer KD, Schaefer DW, Ashley CS. Sol-gel transition in simple silicates. J Non-Cryst Solids 1982; 48: 47-64.

71. Jaakkola T, Rich J, Tirri T, Närhi T, Jokinen M, Seppälä J, Yli-Urpo A. In vitro Ca-P precipitation on biodegradable thermoplastic composite of $\operatorname{poly}(\varepsilon$ caprolactone- $c o$-DL-lactide) and bioactive glass (S53P4). Biomaterials 2004; 25: $575-581$.

72. Eglin D, Maalheem S, Livage J, Coradin T. In vitro apatite forming ability of type I collagen hydrogels containing bioactive glass and silica sol-gel particles. J Mater Sci: Mater Med 2006; 17: 161-167.

73. Oyane A, Minoda M, Miyamoto T, Takahashi R, Nakanishi K, Kim HM, Kokubo T, Nakamura T. Apatite formation on ethylene-vinyl alcohol cpopolymer modified with silanol groups. J Biomed Mater Res 1999; 47: 367-373.

74. Oliveira AL, Mano JF, Reis RL. Nature-inspired calcium phosphate coatings: present status and novel advances in the science of mimicry. Curr Opin Solid St M 2003; 7: 309-318.

75. Zainuddin, Hill DJT, Whittaker AK, Lambert L, Chirila TV. Preferential interactions of calcium ions in poly(2-hydroxyethyl metyhacrylate) hydrogels. J Mater Sci: Mater Med 2007; 18: 1141-1149.

76. Leonor IB, Kim HM, Balas F, Kawashita M, Reis RL, Kokubo T, Nakamura T. Functionalization of different polymers with sulfonic groups as a way to coat them with a biomimetic apatite layer. J Mater Sci: Mater Med 2007; 18: 1923-1930. 
References

77. Oréfice R, Clark A, West J, Brennan A, Hench L. Processing, properties, and in vitro bioactivity of polysulfone-bioactive glass composites. J Biomed Mater Res: A 2007; 80: 565-580.

78. Yu S, Hariram KP, Kumar R, Cheang P, Aik KK. In vitro apatite formation and its growth kinetics on hydroxyapatite/polyetheretherketone biocomposites. Biomaterials 2005; 26: 2343-2352.

79. Fang L, Leng Y, Gao P. Processing of hydroxyapatite reinforced ultrahigh molecular weight polyethylene for biomedical applications. Biomaterials 2005; 26: 3471-3478.

80. Li Z, Yubao L, Aiping Y, Xuelin P, Xuejiang W, Xiang Z. Preparation and in vitro investigation of chitosan/nano-hydroxyapatite composite used as bone substitute materials. J Mater Sci: Mater Med 2005; 16: 213-219.

81. Jie W, Yubao L. Tissue engineering scaffold material of nano-apatite crystals and polyamide composite. Eur Polym J 2004; 40: 509-515.

82. Eglin D, Ali SAM, Perry CC. Comparative study of the in vitro apatiteforming ability of poly( $\varepsilon$-caprolactone-silica sol-gels using three osteoconductivity tests (static, dynamic, and alternate soaking process). J Biomed Mater Res: A 2004; 69: 718-727.

83. Zhao L, Chang J. Preparation and characterization of macroporous chitosan/wollastonite composite scaffolds for tissue engineering. J Mater Sci: Mater Med 2004; 15: 625-629.

84. Li X, Chang J. Preparation and characterization of bioactive collagen/wollastonite composite scaffolds. J Mater Sci: Mater Med 2005; 16: 361365 .

85. Day RM, Maquet $\mathrm{V}$, Boccaccini $\mathrm{AR}$, Jérôme $\mathrm{R}$, Forbes $\mathrm{A}$. In vitro and in vivo analysis of macroporous biodegradable poly(D,L-lactide- $c o$-glycolide) scaffolds containing bioactive glass. J Biomed Mater Res: A 2005; 75: 778-787.

86. Meretoja VV, Helminen AO, Korventausta JJ, Haapa-aho V, Seppälä, JV,

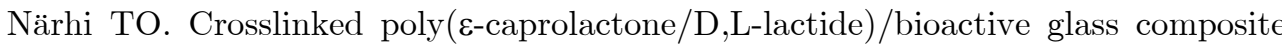
scaffolds for bone tissue engineering. J Biomed Mater Res: A 2006; 77: 261-268. 
87. Rezwan K, Chen QZ, Blaker JJ, Boccaccini AR. Biodegradable and bioactive porous polymer/inorganic composite scaffolds for bone tissue engineering. Biomaterials 2006; 27: 3413-3431.

88. Seregin V, Coffer JL. Biomineralization of calcium disilicide in porous polycaprolactone scaffolds. Biomaterials 2006; 27: 4745-4754.

89. Huang SL, Chin WK, Yang WP. Structural characteristics and properties of silica/poly(2-hydroxyethyl methacrylate) (PHEMA) nanocomposites prepared by mixing colloidal silica or tetraethyloxysilane (TEOS) with PHEMA. Polymer 2005; 46: $1865-1877$.

90. Constantini A, Luciani G, Annunziata G, Silvestri B, Branda F. Swelling properties and bioactivity of silica gel/pHEMA nanocomposites. J Mater Sci: Mater Med 2006; 17: 319-325.

91. Hajji P, David L, Gerard JF, Pascault JP, Vigier G. Synthesis, structure and morphology of polymer-silica hybrid nanocomposites based on hydroxyethyl methacrylate. J Polym Sci: Polym Phys 1999; 37: 3172-87.

92. Liu YL, Hsu CY, Hsu KY. Poly(methylmethacrylate)-silica nanocomposites films from surface-functionalized silica nanoparticles. Polymer 2005; 46: 1851-1856.

93. Abe Y, Kokubo T, Yamamuro T. Apatite coating on ceramics, metals and polymers utilizing a biological process. J Mater Sci: Mater Med 1990; 1: 233-238.

94. Balas F, Kawashita M, Nakamura T, Kokubo T. Formation of bone-like apatite on organic polymers treated with a silane-coupling agent and a titania solution. Biomaterials 2006; 27: 1704-1710.

95. Oyane A, Kawashita M, Kokubo T, Minoda M, Miyamoto T, Nakamura T. Bonelike apatite formation on ethylene-vinyl alcohol copolymer modified with a silane coupling agent and titania solution. J Ceram Soc Japan 2002; 110: 248-254.

96. Oyane A, Kawashita M, Nakanishi K, Kokubo T, Minoda M, Miyamoto T, Nakamura T. Bonelike apatite formation on ethylene-vinyl alcohol copolymer modified with silane coupling agent and calcium silicate solutions. Biomaterials $2003 ; 24: 1729-1735$. 
References

97. Tanahashi M, Yao T, Kokubo T, Minoda M, Miyamoto T, Nakamura T, Yamamuro T. Apatite coated on organic polymers by biomimetic process: improvement in its adhesion to substrates by $\mathrm{NaOH}$ treatment. J Appl Biomater 1994; 5: 339-347.

98. Tanahashi M, Yao T, Kokubo T, Minoda M, Miyamoto T, Nakamura T, Yamamuro T. Apatite coated on organic polymers by biomimetic process: improvement in its adhesion to substrate by glow-discharge treatment. J Biomed Mater Res 1995; 29: 349-357.

99. Kato K, Eika Y, Ikada Y. Deposition of a hydroxyapatite thin layer onto a polymer surface carrying grafted phosphate polymer chains. J Biomed Mater Res 1996; 32: 687-691.

100. Kawashita AM, Nakao M, Minoda M, Kim HM, Beppu T, Miyamoto T, Kokubo T, Nakamura T. Apatite-forming ability of carboxyl group-containing polymer gels in a simulated body fluid. Biomaterials 2003; 24: 2477-2484.

101. Taguchi T, Muraoka Y, Matsuyama H, Kishida A, Akashi M. Apatite coating on hydrophilic polymer-grafted poly(ethylene) films using an alternate soaking process. Biomaterials 2001; 2: 53-58.

102. Oyane A, Uchida M, Choong C, Triffitt J, Jones J, Ito A. Simple surface modification of poly(E-caprolactone) for apatite deposition from simulated body fluid. Biomaterials 2005; 26: 2407-2413.

103. Tian D, Blacher S, Jerome R. Biodegradable and biocompatible inorganicorganic hybrid materials: 4. Effect of acid content and water content on the incorporation of aliphatic polyesters into silica by the sol-gel process. Polymer 1999; 40: $951-57$.

104. Rhee SH, Choi JY, Kim HM. Preparation of a bioactive and degradable poly(E-caprolactone)/silica hybrid through a sol-gel method. Biomaterials 2002; 23: 4915-21.

105. Rhee SH. Effect of molecular weight of poly(e-caprolactone) on interpenetrating network structure, apatite-forming ability, and degradability of poly(E-caprolactone)/silica nano-hybrid materials. Biomaterials 2003; 24: 17211727. 
106. Catauro M, Raucci MG, De Gaetano F, Buri A, Marotta A, Ambrosio L. Solgel synthesis, structure and bioactivity of polycaprolactone $/ \mathrm{CaO} \cdot \mathrm{SiO}_{2}$ hybrid material. J Mater Sci: Mater Med 2004; 15: 991-95.

107. Wei Y, Jin D, Yang C, Wei G. A fast convenient method to prepare hybrid sol-gel materials with low volume-shrinkages. J Sol-Gel Sci Tech 1996; 7: 191-201.

108. Lin DJ, Chen CC, Chang CL, Su YC, Cheng LP. Observation of nanoparticles in silica/poly(HEMA) hybrid by electron microscopy. J Polym Res 2002; 9: $115-118$.

109. Costa ROR, Vasconcelos WL. Structural modification of poly(2-hydroxyethyl methacrylate)-silica hybrids utilizing 3-methacryloxypropyltrimethoxysilane. J NonCryst Solids 2002; 304: 84-91.

110. Schiraldi C, D'Agostino A, Oliva A, Flamma F, De Rosa A, Apicella A, Aversa R, De Rosa M. Development of hybrid materials based on hydroxyethylmethacrylate as supports for improving cell adhesion and proliferation. Biomaterials 2004; 25: 3645-53.

111. Lin DJ, Chen CC, Su YC, Huang SH, Cheng LP. Preparation of silica-filled poly(2-hydroxymethyl methacrylate) nanocomposites cured by photoirradiation during the sol-gel process. J Appl Polym Sci 2004; 94: 1927-1935.

112. Costa ROR, Pereira MM, Lameiras FS, Vasconcelos WL. Apatite formation on poly(2-hydroxyethyl methacrylate)-silica hybrids prepared by sol-gel process. J Mater Sci: Mater Med 2005; 16: 927-32.

113. Jackson CL, Bauer BJ, Nakatani AI, Barnes JD. Synthesis of hybrid organicinorganic materials from interpenetrating polymer network chemistry. Chem Mater 1996; 8: 727:733.

114. Li C, Wu J, Zhao J, Zhao D, Fan Q. Effect of inorganic phase on polymeric relaxation dynamics in PMMA/silica hybrids studied by dielectric analysis. Eur Polym J 2004; 40: 1807-1814.

115. Costa ROR, Lameiras FS, Vasconcelos WL. Structural control in poly(butyl acrylate)-silica hybrids by modifying polymer-silica interactions. J Sol-Gel Sci Tech 2003; 27: 343-54. 
References

116. Takahashi R, Nakanishi K, Soga N. Aggregation behavior of alkoxide-derived silica in sol-gel process in presence of poly(ethylene oxide). J Sol-Gel Sci Tech 2000; 17: 7-18.

117. Malucelli G, Priola A, Sangermano M, Amerio E, Zini E, Fabbri E. Hybrid nanocomposites containing silica and PEO segments: preparation through dualcuring process and characterization. Polymer 2005; 46: 2872-2879.

118. Zoppi RA, Nunes SP. Hybrids of poly(ethylene oxide-co-epichlorhydrin) and silica: phase separation, morphology and thermal properties. Polymer 1998; 39: 6195-6203.

119. Chen Y, Iroh JO. Synthesis and characterization of polyimide/silica hybrid composites. Chem Mater 1999; 11: 1218-1222.

120. Sengupta R, Bandyopadhyay A, Sabharwal S, Chaki TK, Bhowmick AK. Polyamide 6,6/in situ silica hybrid nanocomposites by sol-gel technique: synthesis, characterization and properties. Polymer 2005; 46: 3343-3354.

121. Landry CJT, Coltrain BK, Landry MR, Fitzgerald JJ, Long VK. Poly(vinyl acetate)/silica filled materials: material properties of in situ vs. fumed silica particles. Macromolecules 1993; 26: 3702-12.

122. Pereira MM, Jones JR, Orefice RL, Hench LL. Preparation of bioactive glasspolyvinyl alcohol hybrid foams by the sol-gel method. J Mater Sci: Mater Med 2005; 16: 1045-1050.

123. Surivet F, Lam TM, Pascault JP, Pham QT. Organic-inorganic hybrid materials. 1. Hydrolysis and condensation mechanisms involved in alkoxysilaneterminated macromonomers. Macromolecules 1992; 25: 4309-4320.

124. Strawbridge I, Craievich AF, James PF. The effect of the $\mathrm{H}_{2} \mathrm{O} / \mathrm{TEOS}$ ratio on the structure of gels derived by the acid catalysed hydrolysis of tetraethoxysilane. J Non-Cryst Solids 1985; 72: 139-157.

125. Hench LL, West JK. The sol-gel process. Chem Rev, 1990; 90: 33-72.

126. El Haskouri J, Ortiz de Zárate D, Guillem C, Beltrán-Porter A, Caldés M, Marcos MD, Beltrán-Porter D, Latorre J, Amorós P. Hierarchical porous nanosized organosilicas. Chem Mater 2002; 14: 4502-4504. 
127. Huerta L, Guillem C, Latorre J, Beltrán A, Martínez-Máñez R, Marcos MD, Beltrán D, Amorós P. Bases for the synthesis of nanoparticulated silicas with bimodal hierarchical porosity. Solid State Sciences 2006; 8: 940-951.

128. Yoldas BE. Introduction and effect of structural variations in inorganic polymers and glass networks. J Non-Cryst Solids 1982; 51: 105-121.

129. Brinker CJ, Scherer GW. Sol-gel-glass: I. Gelation and gel structure. J NonCryst Solids 1985; 70: 301-322.

130. De Farias RF, Airoldi C. Thermogravimetry as a reliable tool to estimate the density of silanols on a silica gel surface. J Thermal Anal 1998; 53: 751-756.

131. Bandyopadhyay A, Bhowmick AK, De Sarkar M. Synthesis and characterization of acrylic rubber/silica hybrid composites prepared by sol-gel technique. J Appl Polym Sci 2004; 93: 2579-2589.

132. Mammeri F, Le Bourhis E, Rozes L, Sánchez C. Mechanical properties of hybrid organic-inorganic materials. J Mater Chem 2005; 15: 3787-3811.

133. Donatti DA, Vollet DR. A calorimetric study of the ultrasound-stimulated hydrolysis of solventless TEOS-water mixtures. J Sol-Gel Sci Tech 1995; 4: 99-105.

134. Donatti DA, Vollet DR. Effects of $\mathrm{HCl}$ on the ultrasound catalyzed TEOS hydrolysis as determined by a calorimetric study. J Non-Cryst Solids 1996; 208: 99104 .

135. Zerda TW, Artaki I, Jonas J. Study of polymerization processes in acid and base catalyzed silica sol-gels. J Non-Cryst Solids 1986; 81: 365-379.

136. Peppas NA, Hilt JZ, Khademhosseini A, Langer R. Hydrogels in biology and medicine: from molecular principles to bionanotechnology. Adv Mater 2006; 18: 1345-1360.

137. Olmedilla MP, García-Giralt N, Pradas MM, Ruiz PB, Ribelles JLG, Palou EC, García JCM. Response of human chondrocytes to a non-uniform distribution of hydrophilic domains on poly(ethyl acrylate-co-hydroxyethyl methacrylate) copolymers. Biomaterials 2006; 27: 1012-1033.

138. Gallego Ferrer G, Salmerón Sánchez M, Gómez Ribelles JL, Romero Colomer FJ, Monleón Pradas M. Nanodomains in a hydroplylic-hydrophobic IPN based on 
References

poly(2-hydroxyethyl acrylate) and poly(ethyl acrylate). Eur Polym J 2007; 43: $3136-3145$.

139. Vidaurre A, Cortazar IC, Meseguer JM. Water sorption properties of poly(ethyl acrylate-co-hydroxyethyl methacrylate) macroporous hydrogels. Macromol Symp 2003; 200: 283-290.

140. Stokols S, Sakamoto J, Breckon C, Holt T, Weiss J, Tuszynski MH. Templated agarose scaffolds support linear axonal regeneration. Tissue Eng 2006; 12: $2777-2787$.

141. Neumann AW, Spelt JK, eds. Applied Surface Thermodynamics. Surfactant Science Series. Volume 63. Marcel Dekker, New York. 1993.

142. Owens DK, Wendt RC. Estimation of surface free energy of polymers. J Appl Polym Sci 1969; 13: 1741.

143. Busscher HJ, Vanpelt AWJ, Deboer P, Dejong HP, Arends J. The effect of surface roughening of polymers on measured contact angles of liquids. Colloids Surf 1984; 9: 319-331.

144. Birdi KS. Surface tension of polymers. In: Yildrim Erbil H, ed. CRC Handbook of surface and colloid chemistry. CRC Press, Boca Raton, 1997. p.: 292.

145. Bosch P, del Monte F, Mateo JL, Levy D. Photopolymerization of hydroxyethylmethacrylate in the formation of organic-inorganic hybrid sol-gel matrices. J Polym Sci: Polym Chem 1996; 34: 3289-3296.

146. Landry CJT, Coltrain BK, Wesson JA, Zumbulyadis N, Lippert JL. In situ polymerization of tetraethoxysilane in poly(methyl methacrylate). Morphology and dynamic-mechanical properties. Polymer 1992; 33: 1486-95.

147. Gedde UW. Polymer physics. Chapman \& Hall, London, 1995. p.: 70.

148. Almirall A, Larrecq G, Delgado JA, Martínez S, Planell JA, Ginebra MP. Fabrication of low temperature macroporous hydroxyapatite scaffolds by foaming and hydrolysis of an $\alpha$-TCP paste. Biomaterials 2004; 25: 3671-3680.

149. Rodríguez Hernández JC, Monleón Pradas M, Gómez Ribelles JL. Properties of poly(2-hydroxyethyl acrylate)-silica nanocomposites obtained by the sol-gel process. J Non-Cryst Solids 2008; 354: 1900-1908. 
150. Huang W, Day DD, Kittiratanapiboon K, Rahaman MN. Kinetics and mechanisms of the conversion of silicate (45S5), borate, and borosilicate glasses to hydroxyapatite in dilute phosphate solutions. J Mater Sci: Mater Med 2006; 17: 583-596.

151. Van Krevelen DW, ed. Properties of polymers. Elsevier, New York, 1997. p.: 238.

152. Ward IM, Hadley DW. An introduction to the mechanical properties of solid polymers. Wiley, England, 1993.

153. Craig RG, Peyton FA. Elastic and mechanical properties of human dentin. J Dent Res 1958; 37: 710-718.

154. Motomatsu M, Takahashi $\mathrm{T}$, Nie $\mathrm{H}$ Y, Mizutani $\mathrm{W}$, Tokumoto H. Microstructure study of acrylic polymer-silica nanocomposite surface by scanning force microscopy. Polymer 1997; 38: 177-182. 



\section{Glossary}

\begin{tabular}{|c|c|}
\hline BMP & bone morphogenetic protein \\
\hline $\mathrm{BPO}$ & benzoyl peroxide \\
\hline DMS & dynamic-mechanical spectroscopy \\
\hline DSC & differential scanning calorimetry \\
\hline $\mathrm{E}^{\prime}, \mathrm{E}_{150^{\circ} \mathrm{C}}^{\prime}$ & storage modulus, storage modulus at $150^{\circ} \mathrm{C}$ \\
\hline $\mathrm{E}_{\text {bulk }}$ & compressive elastic modulus of the bulk sample \\
\hline $\mathrm{ECM}$ & extracellular matrix \\
\hline EDS & energy dispersive X-ray spectroscopy \\
\hline EGDMA & ethylene glycol dimethacrylate \\
\hline EMA & ethyl methacrylate \\
\hline $\mathrm{E}_{\text {scff }}$ & compressive elastic modulus of the scaffold \\
\hline EWC & $\begin{array}{l}\text { equilibrium water content referred to the dry mass of the } \\
\text { sample }\end{array}$ \\
\hline EWC' & $\begin{array}{l}\text { equilibrium water content referred to the HEA mass in the } \\
\text { sample }\end{array}$ \\
\hline $\mathrm{EWC}_{\text {theor }}$ & $\begin{array}{l}\text { equilibrium water content predicted from the EWC values of } \\
\text { PEMA and PHEA }\end{array}$ \\
\hline EWEC & $\begin{array}{l}\text { equilibrium water/ethanol content referred to the dry mass of } \\
\text { the sample }\end{array}$ \\
\hline EWEC' & $\begin{array}{l}\text { equilibrium water/ethanol content referred to the copolymer } \\
\text { mass in the sample }\end{array}$ \\
\hline
\end{tabular}


EWEC $_{\text {theor }} \quad$ equilibrium water/ethanol content predicted from the EWEC values of PEMA and PHEA

FGF fibroblast growth factor

FTIR Fourier transform infrared spectroscopy

HAp hydroxyapatite

HEA hydroxyethyl acrylate

HPF human pulp fibroblast

ICP-AES inductively coupled plasma atomic emission spectroscopy

IP $\quad$ ionic activity product

MTT 3-(4,5-dimethylthiazol-2-yl)-2,5-diphenyltetrazolium bromide

OCP octacalcium phosphate, $\mathrm{Ca}_{8} \mathrm{H}_{2}\left(\mathrm{PO}_{4}\right)_{6} \cdot 5 \mathrm{H}_{2} \mathrm{O}$

P(EMA), PEMA poly(ethyl methacrylate)

P(EMA-co-HEA) poly(ethyl methacrylate- $c o$-hydroxyethyl acrylate)

$\mathrm{P}$ (EMA-co-HEA)/ $\mathrm{SiO}_{2}$ poly(ethyl methacrylate-co-hydroxyethyl acrylate)/silica

P(HEA), PHEA poly(hydroxyethyl acrylate)

PAN polyacrylonitrile

PGA polyglycolic acid

PLLA polylactic acid

SBF simulated body fluid

SEM scanning electron microscopy

$\mathrm{SiO}_{2 \mathrm{EDS}} \quad$ silica content calculated from the Si content obtained by EDS

$\mathrm{T}_{\alpha} \quad$ temperature of the maximum in $\tan \delta$

$\tan \delta \quad$ loss tangent

TCP tricalcium phosphate, $\mathrm{Ca}_{9}\left(\mathrm{PO}_{4}\right)_{6}$

TEM transmission electron microscopy 
TEOS

$\mathrm{T}_{\mathrm{g}}$

TGA

TMOS

$\mathrm{w}, \mathrm{w}_{700^{\circ} \mathrm{C}}$

$\mathrm{x}$

XRD

$\Delta c_{p}$

$\Delta \mathrm{T}_{\mathrm{g}}$

$\beta$-TGF

$\gamma_{\mathrm{s}}$

$\gamma_{\mathrm{s}}^{\mathrm{d}}, \gamma_{\mathrm{s}}^{\mathrm{p}}$

$\pi$

$\rho$

$\rho_{\text {theor }}$ tetraethoxysilane, tetraethyl orthosilicate

glass transition temperature

thermogravimetry

tetramethoxysilane

residual mass in TGA measurement, TGA residue at $700^{\circ} \mathrm{C}$

mass fraction of the copolymer able to undergo conformational motions at the glass transition

X-ray diffractometry

specific heat capacity increment at the glass transition

width of the glass transition

$\beta$-transforming growth factor

surface tension

dispersive and polar components of the surface tension

porosity

density

density considering the most efficient packing of the phases 
